Fig. $3 a$. Head and antennæ of the same, dorsal view.

$3 \mathrm{~b}$. Tail-segments of the same, dorsal view, both further magnified.

4. Porcellio flavo-vittata, p. 669 , dorsal view, magnified twice the natural size.

4a. Head and antennæ of the same, inferior view.

$4 \mathrm{~b}$. Segments of the tail, dorsal view, both further magnified.

5. Porcellio hispida, p. 676, dorsal view, magnified twice the natural size.

5 a. Tail-segments of the same, further magnified.

6. Anilocra lavis, p. 672 , natural size.

$6 a$. Front and antennæ, magnified.

$6 b$. One of the legs of the last pair.

6 c. Uropoda, further magnified.

\title{
Plate LXIX.
}

Fig. 1. Acanthonyx elongatus, p. 673, natural size.

2. Tylos granulatus, p. 674 , lateral view, natural size.

$2 a$. Head and antennæ, dorsal view.

$2 b$. Segments of the tail, dorsal view, both further magnified.

3. Philougria nitida, p. 670 , dorsal view, magnified twice the natural size.

$3 a$. Head and antennæ, dorsal view.

$3 \mathrm{~b}$. Tail-segments, dorsal view, both further magnified.

4. Lironeca daurica, p. 676, dorsal riew, natural size.

$4 a$. Head and antennæ, dorsal view.

$4 b$. One of the legs of the first pair.

4c. Uropod: all further magnified.

5. Lironeca laticauda, p. 677 , dorsal view, natural size.

5 a. Head and antennæ, inferior view.

$5 \mathrm{~b}$. One of the legs of the first pair.

$5 c$. Uropod: all further magnified.

6. Anilocra trichiura, p. 677 , dorsal view, natural size.

$6 a$. One of the legs of the first pair, magnified.

November 6th, 1877.

Arthur Grote, Esq., V.P., in the Chair.

The Secretary read the following reports on the additions to the Society's Menagerie during the months of June, July, August, and September 1877:--

The total number of registered additions to the Society's Menagerie during the month of June was 166, of which 87 were by birth, 35 by presentation, 25 by purchase, 1 by exchange, and 18 were received on deposit. The total number of departures during the same period by death and removals was 92 .

The most noticeable additions during the month of June were as follows :-

1. A White-cheeked Gibbon (Hylobates leucogenys), presented by W. H. Newman, Esq., H.B.M. Consul, Siam, Bangkok, June 2nd, and kindly brought to this country under the care of Mr. A. R. Houghton in the steamship 'Agamemnon.' The White-cheeked Gibbon was described many years ago in the Society's 'Proceedings' (P. Z. S. 1840, p. 20) by the late Mr. Ogilby, upon an animal which had been living in the Society's Menagerie, and of which the exact habitat was unknown. The typical specimen is now in the British 
Museum. So far as I know, no second individual of this wellmarked species of Hylobates has since occurred; it is therefore of the greatest interest to have obtained a specimen from a distinct locality $^{1}$. Our present individual, which is a young male, seems to agree in every respect with Mr. Martin's description and figure (Nat. Hist. of Man and Monk. p. 445).

Mr. Smit's figure (Plate LXX.) will, I trust, serve to make this interesting species better known.

2. A Tibetan Partridge (Perdix hodgsonia, Gould) ${ }^{2}$, presented by Monsieur J. M. Cornély, of Tours, C.M.Z.S., on the 16th June, being, so far as I am aware, the first example of this fine representative of this well-known species that has been received by the Society. A second specimen of the same bird has since been purchased from Mr. W. Jamrach, from whom, I believe, M. Cornély obtained his specimen.

3. A young male Hippopotamus, received June 20th, having been purchased of the Royal Zoological Society of Amsterdam for the sum of $£ 800$.

The original pair of Hippopotamuses, obtained from the Viceroy of Egypt (the male in 1851, and the female in 1854), being both now well advanced in years and having ceased to breed, the Council thought that it would not be right to miss an opportunity of obtaining a mate for the Society's young female of this species, born in the Gardens on the 5th November, 1872.

The Council accordingly entered into an agreement with the sister Society at Amsterdam for the acquisition of the young male Hippopotamus, which was born in their gardens on the 3rd of August, 1876, and which arrived safely in this country under the care of Mr. Hegt, the subdirector of their Gardens, on the 20th June last. The young animal, which now measures about 2 feet 6 inches in height, has hitherto been fed nearly exclusively on Goat's milk, but is now beginning to take more substantial diet, and appears to be in every way thriving.

4. A fine example of the black variety of the common Leopard (Felis pardus), from Lahore, Malay peninsula, presented by Sir Harry St. George Ord, C.B., F.Z.S.

5. Twenty Common Boas (Boa constrictor), produced alive by one of the Boas in the Society's Gardens on the 30th June. This is the first occasion in which this Serpent has bred in the Society's Gardens ; and, so far as I am aware, the fact of the Boa producing living ones was not certainly known. The young Boas are about 15 inches in length, and are lively and active, threatening to bite if touched. They are already beginning to feed; and we have good hopes that some of them, at least, may be reared ${ }^{3}$.

1 The notice given by Mr. Blyth (P. Z.S. 1841, p. 63) of the supposed occurrence of this species on the Ghauts of Malabar is, no duubt, founded on some error.

2 See Gould's 'Birds of Asia,' pt. ix. May 1, 1857, for a figure of this species.

${ }^{3}$ P.S. (November 6th).-All of these Boas, except one, are still alive and in good condition. 


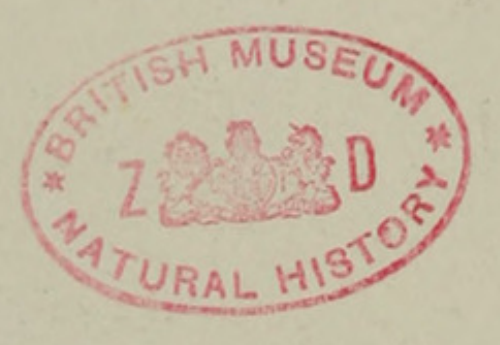


I

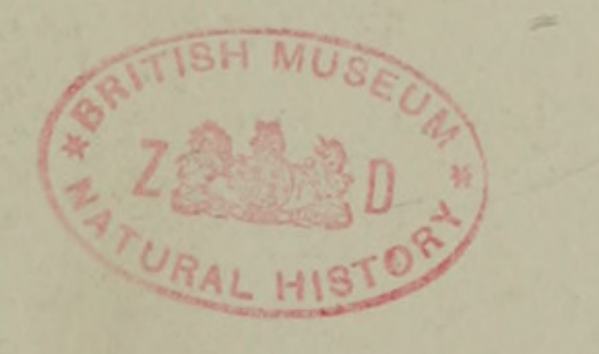




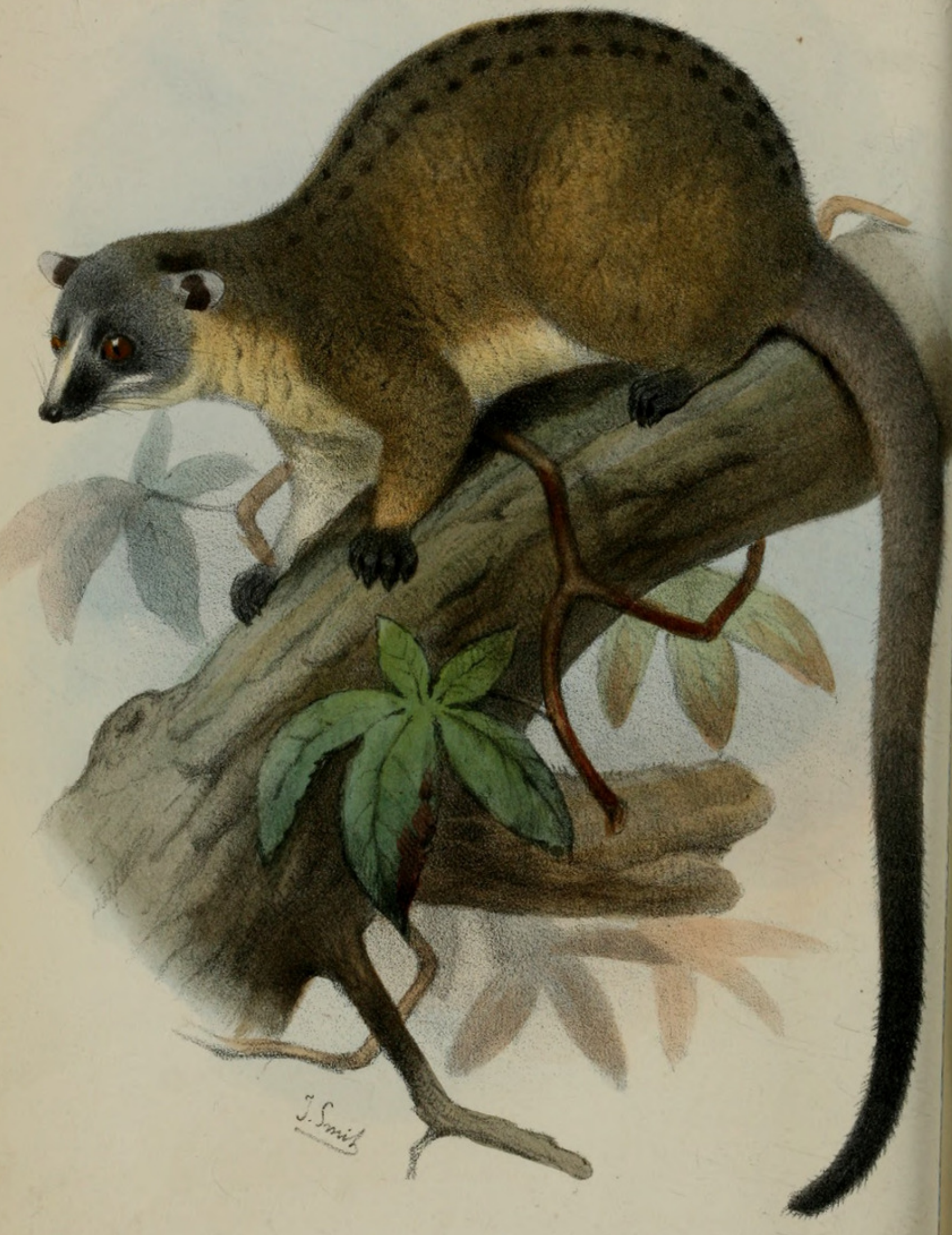


The total number of registered additions to the Society's Menagerie during the month of July was 145; of these, 54 were acquired by presentation, 48 by purchase, 5 by exchange, 22 by birth, and 16 were received on deposit. The total number of departures during the same period, by death and removal, was 102 .

The most noticeable additions during the month were :-

1. A Prehensile Paradoxure (Paradoxurus prehensilis) ${ }^{1}$, from Assoun, on the Hounderaw river, about 90 miles from Moulmein, Burmah, presented July 13th, by W. H. Pattison, Esq.

This Paradoxure (Plate I.XXI.) is of a well-marked and peculiar species, quite new to us, and appears to be little known except from the figure in Hardwicke and Gray's 'Indian Zoology' (ii. pl. 9), taken from a drawing of Buchanan-Hamilton. Its tail is very long and slender, and appears to be slightly prehensile.

2. A Urumutum Curassow (Nothocrax urumutum), from the Upper Amazons, purchased July 16th. When I communicated to the Society my memoir on the Curassows in 1873 (see Trans. Zool. Soc. ix. p. 273) I was unable to figure this rare species from a living example. As will be seen by the coloured sketch now exhibited, the bare skin over the eye was, in consequence, coloured wrongly, the upper portion over the eye being bright yellow instead of blue.

3. A Crane, obtained from Chantung, in Northern China, and kindly transmitted to the Society by Mr. Theodore Hance, of Chingkiang. It appears to belong to the eastern form of the Common Crane, called Grus longirostris in the 'Fauna Japonica.'

Comparing this bird (of which I exhibit a sketch by Mr. Smit) with the Common Crane of Europe, Grus cinerea, it seems to differ in its lighter colour, and in the uropygial plumes being cinereous with black terminations, instead of being altogether black as in the common species; but I doubt its being specifically different.

The total number of registered additions to the Society's Menagerie during the month of August were 116 in number; of these, 67 were acquired by presentation, 19 by purchase, 4 by birth, 8 by exchange, and 18 received on deposit. The total number of departures during the same period by death and removals were 110 .

The most noticeable additions during the month were: -

1. A Cape Hedgehog (Erinaceus frontalis), purchased August $13 \mathrm{th}$, being the first example of this southern representative of our familiar British species that has reached us.

2. A young example of the American Tantalus (Tantalus loculator), purchased August 30th.

3. A Brazilian Motmot (Momotus brasiliensis), purchased on the same day. Both these birds belong to species hitherto unrepresented in the Society's Aviaries.

I may take this opportunity of pointing out that, as suggested to me by Prof. Garrod, the male Deer, which we have had for some

1 Viverra prehensilis, Desm. See Horsf. Cat. Mamm. E.I. C. p. 63. 
years in the Gardens under the name of Cervus duvaucelli ${ }^{1}$, appears to belong to the allied species Cervus schomburgki of Siam.

The animal in question was received in exchange from the Zoological Gardens of Hamburg on the 1st of November, 1873. On in-

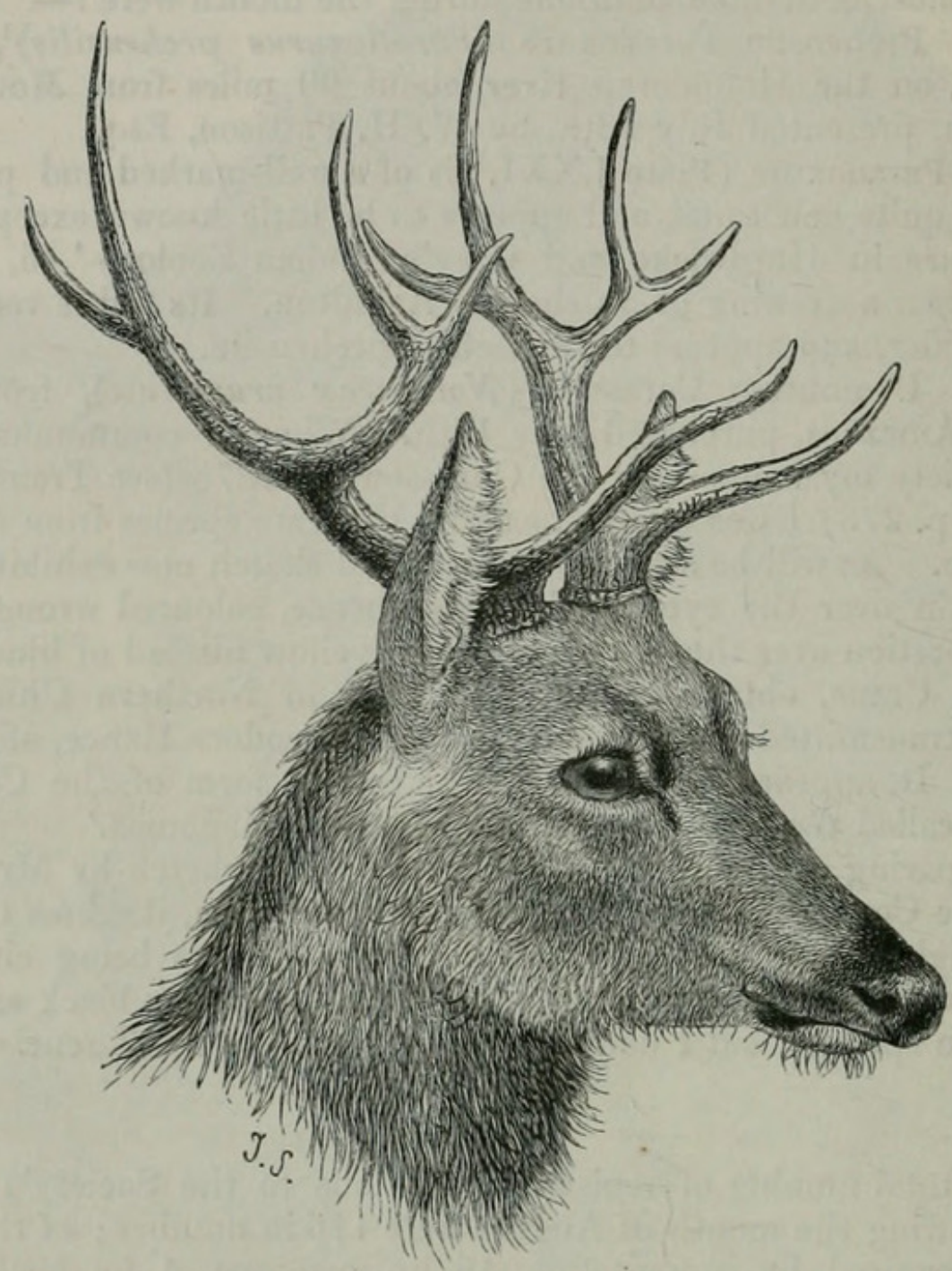

Head of Cervus schomburgki.

quiry, Dr. Bolau, the Secretary of the Zoological Society of Hamburg, has kindly informed me that it was born in the Gardens on July 15 th of the same year, having been bred between a male, said to have come from Bangkok in 1862, and a female received from Berlin, which is also believed to have come from Siam.

The total number of registered additions to the Society's Menagerie during the month of September was 81 ; of these, 31 were acquired by presentation, 25 by purchase, 7 by birth, and 18 were received on deposit. The total number of departures during the same period by death and removals was 101 .

1 See 'List of Vert.' (sixth edition) p. 134. sp. $484 f$. 
The most noticeable additions during the month were as follows :1. Two Guilding's Amazons (Chrysotis guildingi), from St. Vincent's, West Indies, purchased September 15th. These fine Parrots are now said to be very scarce in their native Island of St. Vincent, to which they are peculiar.

2. Two Slaty Coots (Fulica ardesiaca) from Western Peru, purchased September 18th, being the first examples of this interesting representative of our Common Coot that have reached us.

The Secretary read the following extract from a letter addressed to him by Mr. R. Trimen, C.M.Z.S., dated Soth-African Museum, Cape Town, July 27th, 1877 :-

"With reference to your note on the species of Sarcidiornis (P. Z. S. 1876, pp. 694, 695), I think it may be useful to offer a few remarks on two specimens of the African form contained in the collection of this Museum, one of which was received from the Zambesi, and the other obtained in exchange from the late Mr. C. J. Andersson, who brought it from Damara Land.

"I have no Indian specimens with which to compare these African birds; but, taking Mr. Smit's figure (P. Z. S. 1876, pl. lxvii.) as an accurate representation of S. melanonota, the two birds to which I refer differ in the following particulars from the Indian form, viz. :-

"(1) The white of the neck encroaches considerably on the back between the shoulders.

"(2) The curved black streak from the shoulder downward is much more attenuated.

"(3) The under tail-coverts are pure white, without the slightest trace of the bright yellow shown in the figure. (Is it possible that the yellow may have been present in the living specimens, but have faded out in course of time, like that of Chalcites smaragdineus?)

"(4) The secondaries and greater coverts are not of the copperybrown hue depicted in the plate, but mixed metallic-green and bronze with violet reflexions.

"(5) The caruncle on the bill is higher in proportion to its base; it is more vertically elevated anteriorly, and more rounded and sloping posteriorly than is shown in the figure. (This difference may, however, be the effect of shrinking or some defect in mounting our specimens.)

"I should also mention that the lower part of the back is dirty whitish-grey, shading into the metallic-glossed black of the rump.

"You will be better able than myself to judge whether the dif.

- ferences mentioned are of specific value; my own impression is that they are."

A letter was read from Mr. A. O. Hume, C.B., containing some criticisms on Mr. Howard Saunders's review of the Sterninæ, published in the Society's 'Proceedings' for 1876 (p. 638). Mr. Hume was of opinion that the bird figured (plate lxi. fig. 2) as Anous melanogenys, was not that species, but $A$. leucocapillus. 
The Secretary exhibited, on the part of Mr. G. Dawson Rowley, F.Z.S., an egg of Pauxis galeata, and read the following note by Mr. Rowley on the subject:-

"This egg of Pauxis galeata was laid June 30, 1877, by a black female, exactly like the male, except that in size she is a trifle smaller. The two birds have been kept by themselves for several years in a large aviary. The brown form of female ${ }^{1}$ is also here in a different cage; and no communication has been allowed. The black female lays eggs epery year; but they have been previously always broken. All the birds have been in my possession about eight or nine years.

Prof. Flower, F.R.S., V.P., read "A further Contribution to our Knowledge of the existing Ziphioid Whales, of the Genus Mesoplodon."

This communication contained a description of two skeletons and several skulls of Cetaceans of the genus Mesoplodon from New Zealand, sent to England by Dr. Hector and Dr. J. v. Haast, preceded by a review of the species of the genus at present ascertained to exist. These appeared to be the following :-

1. M. bidens (Sowerby) $=M$. sowerbiensis of Blainville and most other authors.

Hab. European Seas.

2. M. europaus, Gervais.

$H a b$. North coast of France.

One example only known.

3. M. densirostris (Blainville) $=M$. seychellensis (Gray).

Hab. Indian Ocean, Australia.

4. M. layardi (Gray) $=M$. longirostris, Krefft $=M$. floweri, Haast $=$ Callidon guenther, Gray $=$ Dolichodon traversii, Gray.

Hab. Indian Ocean, Australia, New Zealand.

5. $M$. hectori (Gray)- = M. knoxi, Hector.

Hab. New Zealand.

Known only by a single individual, of which the skull, now in the British Museum, is described in the present communication.

6. $M$. grayi, Haast $=$ Oulodon grayi, Haast.

Hab. New Zealand.

A complete skeleton, in the Museum of the Royal College of Surgeons, is described in the present memoir.

7. $M$. haasti, n. sp., = M. hectori (Gray), Hector, Trans. N.Z. Inst. vol. vi. p. 86, and vol. vii. p. 362 .

Hab. New Zealand.

A complete skeleton, now in the British Museum, described in the present memoir.

This memoir will be published entire in the Society's 'Transactions.'

1 Cf. Sclater, Trans. Zool. Soc. vol. ix. p. 285, pl. liii. et P.Z. S. 1870 , p. 669. 
The following papers were read :-

1. Descriptions of new Reptiles from the Madras Presidency. By Lieut.-Colonel R. H. Beddome, C.M.Z.S.

[Received June 25, 1877.]

\section{Oligodon travancoricum, n. sp.}

Belly with quadrangular black spots. Scales in seventeen rows; labials seven (the sixth does not enter the labial margin), one loreal, one anteocular, two postoculars; temporals $1+2$. Head with symmetrical black markings; a black band over the postfrontals and vertical, descending through the eye ; and another black band descends to corner of mouth. Body brown, with about twenty-nine nearly regular cross bars of black edged with white, each being the breadth of two scales.

$H a b$. South-Travancore mountains, 3000 feet elevation.

A single specimen only was found; the position of the sixth labial away from the labial margin is probably not constant. Dr. Günther states that it occurs in Simotes venustus; but in two specimens of that Snake now in my collection it is excluded in one but not in the other.

\section{Gymnodactylus Jeyporensis, n. $\mathrm{sp}$.}

Of stout form. Body covered with large hexagonal or nearly square scales in only about eighteen rows across, a few about the vertical line being a little reduced in size; scales of the belly smaller and rounded behind, in about thirty series across. Head covered with small, bead-like, rounded scales; upper labials ten, the last two very small; lower labials seven, the last minute; median lower labial large, pointed behind, with a large pair of chin-shields behind it; subcaudals larger than the scales of the belly. Tail with two tubercles on each side close to the vent; pupil elliptic; opening of the ear subhorizontal. Colour of a light grey, irregularly blotched with dark brown; head with small blotches; nape with two large lunate blotches, one behind the other; body with three 8 -shaped blotches, which, however, do not meet, and smaller intermediate markings; tail irregularly blotched.

Length $3 \frac{1}{2}$ inches; no femoral nor præanal pores.

$H a b$. Jeypore hills.

A single example was captured in a wood on the top of the Patinghe hill, 4200 feet elevation. In coloration somewhat like $G$. collegalensis (mihi); but that species has fine granular scales, in about fifty series across the back. This is a larger and stouter species, with more the facies of a Eublepharis, but without eyelids.

Bufo travancoricus, n. sp.

Crown flat, without any bony enlargement ; snout triangular, projecting; canthus rostralis not very distinct ; first, second, and third

Proc. Zool. Soc.-1877, No. XLV. 
fingers of about equal length ; third nearly double as long; carpus with a very large smooth tubercle; toes webbed; metatarsus with two small tubercles; no fold on the tarsus; tympanum very small; parotoid elongate, rather indistinct, four times as long as broad. Body and belly covered with warty tubercles; the arms and legs quite spiny. Colour blackish brown; the thighs, arms, and legs beautifully marbled with carmine ; the tubercles of the body often tipped with the same colour; those of the belly often whitish.

Length of body $1 \frac{3}{4}$ inches, hind legs 2 inches.

Hab. Travancore.

A single specimen was captured, under an old rotten log, in dense moist forests, above the Ayen-Coil pass (Trarancore), at about 2500 feet elevation; its nearest ally is the B. kelaartii, a Ceylonese species.

In the same forest was captured a fine large species of Dendrophis, with almost exactly the coloration of Ptyas mucosa, and no trace of a yellowish lateral band; the scales in fifteen rows, the vertical row very much enlarged and hexagonal, and the two next rows rather enlarged; but as the plates of the head are in every way quite similar to those of Dendrophis pictus, and it does not seem to differ from that species in any thing but coloration; I do not like to consider it a new species; it is, however, a new variety, I think.

2. Contributions to the Ornithology of the Philippines.No. I. On the Collection made by Mr. A. H. Everett in the Island of Luzon. By Автнur, Marquis of Tweeddale, F.R.S., President of the Society.

[Received July 16, 1877.]

\section{(Plates LXXII. and LXXIII.)}

Mr. Everett, so favourably known as an able, energetic and zealous field-naturalist, and as one of the foremost explorers of the fauna of Borneo, arrived in the Island of Luzon in the beginning of this year, and, after overcoming the official difficulties which sometimes obstruct scientific investigations in the Philippine Islands, commenced collecting zoological specimens at Monte Alban and San Mateo, stations not far from Manilla. Among other objects Mr. Everett secured some 361 specimens of birds in part of the month of January, in February, and in the beginning of March, 1877. These he has kindly consigned to me ; and I propose to give an account of them, adding in each instance the original notes on the labels made by Mr. Everett. Eighty-five species are represented in the collection; and although the neighbourhood of Manilla might with justice be considered as having been exhausted by former collectors, Mr. Everett has discovered three undescribed species, besides adding many more to the already known Luzon, and a few to the Philippine avifauna.

In my memoir on the Birds inhabiting the Philippine Archi- 


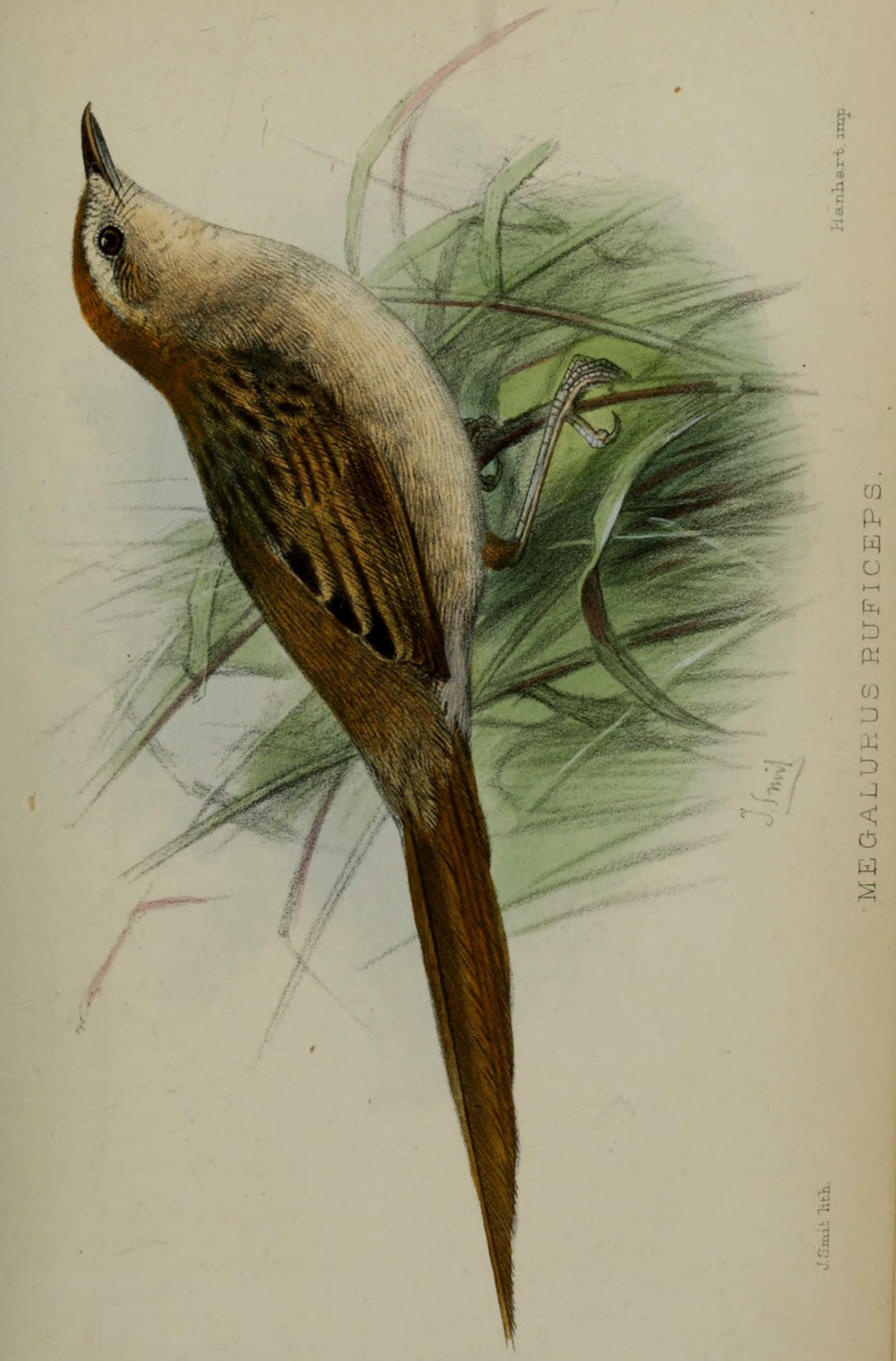




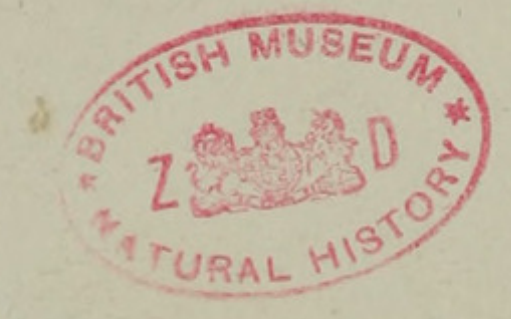




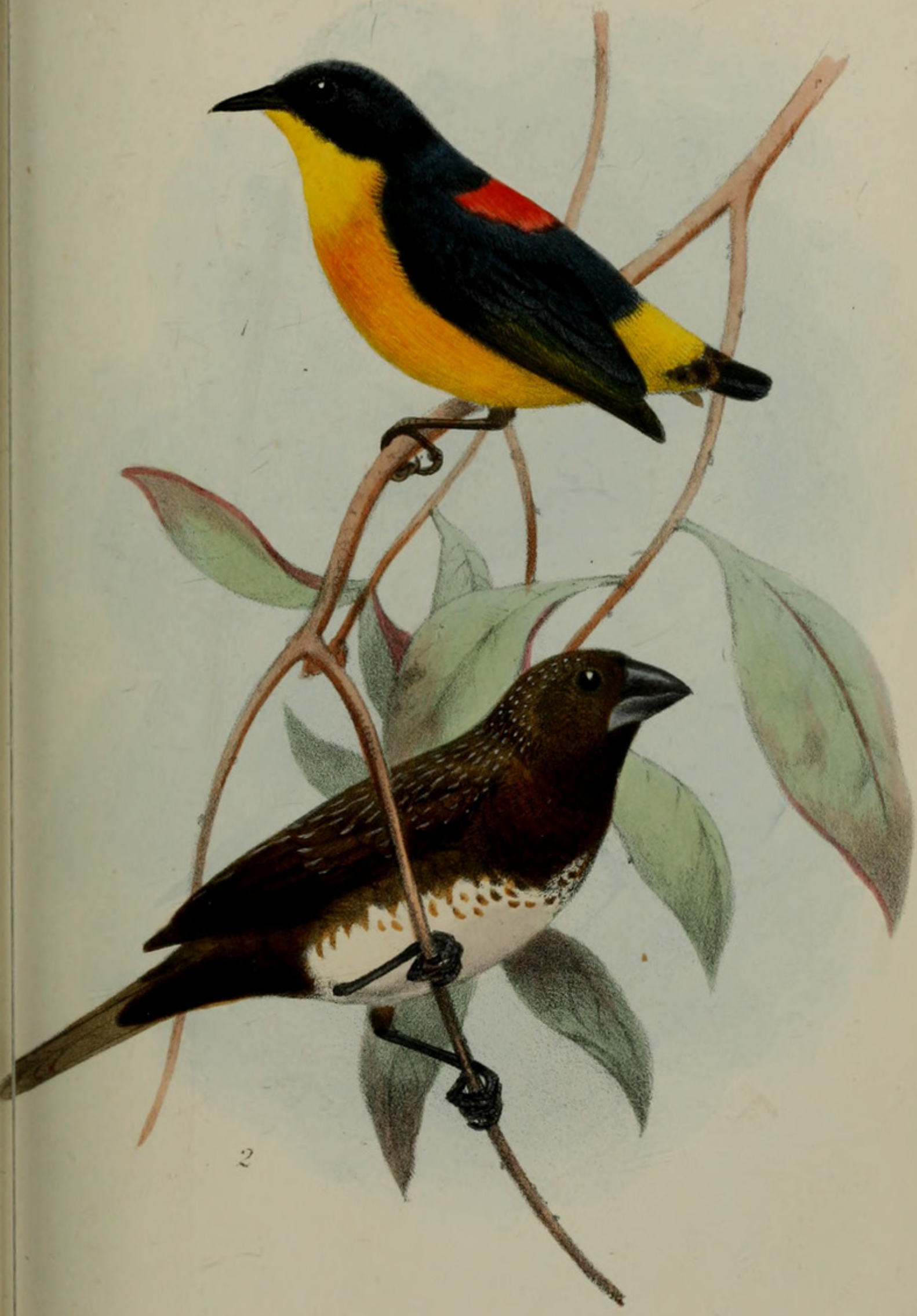

Snit lith 

pelago ${ }^{1}$ I enumerated 218 species. This number must be diminished by one, Circus aruginosus, Mr. H. Cuming's Philippine specimen, catalogued under that title by Mr. Sharpe (Cat. Accipitres B. Mus. p. 71), my only authority, being now considered by Mr. Sharpe to be $C$. spilonotus, jr. (see Ibis, 1876, p. 31). Further, I have reason to doubt the Philippine habitat of so-called Crateropus caudatus (no. 97). To the net total of 216 species Mr. Sharpe has been able to add some 66 species, for the most part obtained by Dr. Steere ${ }^{2}$. This total is partly arrived at by including 23 species from the island of Palawan, 4 from that of Balabac, and 4 from the Sooloo Islands. In a footnote ( $t . c$. p. 126) I excluded the Sooloo archipelago from the Philippine area ; and as we have only the evidence of four known Sooloo species of birds to guide us, I am disinclined as yet to concur in Mr. Sharpe's opinion that these islands ought to be included. Nor am I quite certain that Palawan and still more Balabac should not be excluded. That Palawan certainly is a border region, intervening between Borneo and the Philippine Islands, is made evident by Dr. Steere's remarkable discoveries ; but the Malayan character of its ornis overpowers the Philippine element; and until its fauna and that of the Sooloo Islands shall have been more completely investigated, I purpose to exclude them from what I consider to be the strictly Philippine area. Deducting, therefore, the 23 Palawan, the 4 Balabac, and the 4 Sooloo species (not known in the Philippine archipelago as restricted by me) from Mr. Sharpe's list (t.c. p. 350 ), in all we have a total of 35 purely Philippine birds added by Dr. Steere to my amended number of 216 , making 251 in all. The naturalists of the 'Challenger' Expedition added 11 more (see my paper above, p. 537), making an amended total of 262 Philippine species; and to this number Mr. Everett has enabled me to add 6 from Luzon, namely three new species,
Megulurus ruficeps,
Dicaum xanthopygium,
Oxycerca everetti,

two not hitherto recorded,

Motacilla ocularis,

Anthus maculatus,

and one previously supposed to be a Malayan species,

\section{Turnix fasciatus.}

So 268 species of birds may at this date be considered the total number known to occur in the Philippine Islands, exclusive of Palawan, Balabac, and the Sooloos.

1 Trans. Zool. Soc. 1875, ix. pp. 125-252.

2 Sharpe, Trans. Linn. Soc. ser. 2, Zool. i. p. 307. This number is less by two than Mr. Sharpe's estimate (t.c. p. 308), in consequence of my not being able to recognize Chysocalaptes maculiceps, Sharpe, as being distinct from C. lucidus (Scop.), and Hirundo rustica of the Islands as differing from $H$. gutturalis. Brachyurus propinquus, Sharpe, ex Mindanao, does not appear to be distinct from Erythropitta erythrogastra, ex Luzon, though the Balabac type may be different. Perhaps the Zebu Cyornis, $C$. banyumas of my list (no. 84), may have to be added as constituting a distinct species; for it appears to differ speeifically from C. philippensis, Sharpe, ex Luzon and Panay. 
In the Table showing the geographical distribution of the Philippine birds $(t . c$. pp. 249, 252) I enumerated 57 the exact habitat of which had not been established. From this, one species (the so-called Crateropus caudatus) must be deducted. Mr. Sharpe has been able most satisfactorily to reduce the number by 8 (t. c. p. 308$)$; and $\mathrm{Mr}$. Everett's discoveries enable me to still further diminish the number by 9 .

Philippine species of which the exact habitat has been determined by $\mathrm{Mr}$. Everett :-

Caprimulgus griseatus.

Calliope camtschatkensis.

Phylloscopus borealis (olim magnirostris).

Orthotomus derbianus.

Parus elegans.

Geopelia striata.

Turnix ocellata.

Hypotanidia philippensis.

Ardetta cinnamomea.

So the precise habitats of only 39 species now remain undetermined.

The total number of species known to be resident in the island of Luzon I estimated (t.c.) at $133^{1}$; but Mr. Sharpe has correctly pointed out that Cataguan, which I had treated as a separate island, forms, in reality, part of the island of Luzon. Puffinus leucomelas, which I recorded from there, must be added to the number of Luzon birds ; and to this Mr. Sharpe adds Zeocephus rufus and Penelopides panini ${ }^{2}$, obtained by Mr. Cuming at Cataguan, and Erythropitta erythrogastra, on the faith of a Manilla example so labelled in Mr. Gould's collection. To this amended total of 137 Luzon species Mr. Everett has enabled me to add the 9 species already removed above from the general Philippine list, the 3 undescribed species and the 3 other species new to the fauna above mentioned, besides the following 8 residents of other Philippine islands :-

Eudynamis mindanensis.

Lanius nasutus.

Lalage dominica.

Hirundo gutturalis.
Copsychus mindanensis.

Corydalla lugubris.

Arachnechthra jugularis.

Rhynchaa capensis.

The exact total of known Luzon residents will therefore now amount to 160 .

\section{Prioniturus discurus $(2)^{3}$.}

[Monte Alban. $a, \delta$ : iris brown; bill lead-grey; feet bluish grey; nails dark grey. $b, \sigma^{*}$ : iris chocolate-brown; bill lead-grey; feet bluish grey; claws dark grey.]

A series of seven examples, $\delta$ and shot in February, is sent by Mr. Everett, all being in bright green plumage without a trace of blue on the head. The elongated naked shafts of the middle pair of rectrices greatly vary in length, some being only half an inch, others two inches in length. In two examples these feathers are prolonged for about half an inch, but the shafts are webbed.

1 Conf. Sharpe, t. c. p. 309.

${ }^{2}$ Is it not $P$. manilla?

${ }^{3}$ The numbers following the titles are the same as those of my memoir $(t . c)$. 
2. Cyclopsitta lunulata (4).

[San Mateo. $\delta^{*}$ : iris dark brown; bill black, base pale leadgrey ; feet greenish grey; nails dark grey.]

The male example is in full dress and in P.-loxia plumage. The female has a few verditer-blue chin-, chest-, and throat-plumes, and some of the rump-feathers obscurely lunated-seemingly an immature specimen.

\section{Microhierax erythrogenys.}

Hierax erythrogenys (10).

[Monte Alban. $\$$ : iris brown; bill black; feet dull bluish; claws black.]

Obtained in February. In black and white dress; and as Mr. Everett has ascertained the sex to be female, it would seem that the erythrogenys plumage is significant of nonage and not of sex.

\section{Spiloris holospilus (16).}

[Monte Alban. a o : iris golden-yellow ; bill dark grey ; orbital skin and lores bright yellow-green; cere ditto; claws black; legs yellow.

San Mateo. b, o : iris golden-yellow; bill dark plumbeous; orbital skin and lores bright greenish-yellow; cere ditto, but greener; legs light chrome-yellow ; claws black.]

\section{Haliastur intermedius (17).}

[San Mateo. o juv. : iris warm brown; bill greenish-lead, cere darker; feet greenish yellow, almost white.]

\section{Butastur indicus (20).}

[San Mateo. a, $\delta$ : iris golden yellow; bill chrome-yellow at the base, rest black; cere chrome; legs dull chrome-yellow; claws black. $b, \sigma^{*}:$ iris bright yellow; cere chrome-yellow; bill black; legs dull chrome; claws black.]

\section{Thriponax Javensis (28).}

[Monte Alban. $\sigma^{\pi}:$ bill black ; feet and claws lead-grey.]

8. Chrysocolaptes hematribon (30).

[San Mateo. $a, \delta^{*}:$ iris Indian red; bill greenish black; feet pale dull greenish; claws very dark grey.

Monte Alban. $b, \sigma^{*}$ : iris deep crimson; bill greenish black; feet greenish grey.]

9. Yungipicus maculatus (33).

[Monte Alban. $a, \delta^{0}:$ iris brown; bill black; legs greenish. $b$, + : iris light brown; bill lead-grey ; legs greenish lead-grey.]

Sonnerat's type was obtained in Panay ; but these Luzon individuals agree well with his description. He mentions that his example " $n$ 'a point de rouge," but that perhaps he had only seen a female. The male sent by Mr. Everett possesses a crimson tuft springing from behind the eye. The species is nearly allied to $Y$. fusco- 
albidus, Salvad., ex Java, Sumatra, and Malacca, but is larger, has a more powerful bill, has the white markings on the tertiaries transversely linear rather than rounded, and has the white gular feathers terminated by brown spots.

\section{Merops philippinus (35).}

[San Mateo. $a, \sigma^{*}$; iris blood-red; bill black; feet purplebrown. $b, \delta$ : iris crimson; bill black; feet light greenish. $c$, $q$ : iris blood-red; bill black; legs purple-brown; claws black. $d, q$ : iris blood-red; bill black; feet sooty brown; claws black.

Monte Alban. $e, q$ : iris crimson; bill black; nails ditto; legs greenish.]

A series of seven examples, all obtained in the month of February.

11. Merops bicolor (36).

[Monte Alban. $\sigma^{*}$ : bill black; legs purplish-brown.]

\section{Eurystomus orientalis (37).}

[San Mateo. $\delta^{*}$ : iris brown; bill orange-red; feet coral-red; claws black.]

\section{Alcedo bengalensis (38).}

[Monte Alban. $a, \delta^{\top}$ : iris brown; feet scarlet; claws siennabrown; bill black.]

Identical with Bengal examples.

\section{Entomobia gularis (44).}

[San Mateo. a, o : iris dark brown; bill and legs coral-red; claws sepia-brown. $b, \delta^{\star}$ : iris dark brown; bill and legs coral-red; claws dark brown. $c$ : a frog in the gizzard. $d, \delta^{*}$ : iris chocolate; bill and feet coral-red.

Monte Alban. $e, \delta^{*}$ : iris dark brown ; bill bright red ; feet coralred: nails very dark brown. $f, o^{*}$ : iris dark brown; bill bright red; feet coral-red.]

The plumage of the two sexes does not differ.

\section{Sauropatis ChLORIS (47).}

[Monte Alban. $q$ : iris and feet dark brown; bill black, lower half whitish.]

\section{Actenoides lindsayi (49).}

[Monte Alban. $a, \delta$ : iris brown; bill black, the mandible and culmen yellow; legs light green. $b$, $q$ : iris brown; upper half of beak black, culmen and lower half chrome-yellow; feet light green, claws horn-yellow.]

\section{Xantholema hemacephala (50).}

[Monte Alban. $\delta$ : iris dark hazel-brown ; orbital skin crimson ; bill black; legs and feet coral-red; nails greyish black.]

18. Caprimulgus griseatus (56).

[San Mateo. $a, \delta$ : iris dark brown; tip of bill ditto ; legs light 
purple-brown; nails black. $b, \delta$ : iris dark chocolate; feet purplegrey.]

Seen from above, this Nightjar is difficult to distinguish from five examples of $C$. affinis, ex Lombock. Underneath it conspicuously differs in having the ventral plumage and the thighcoverts transversely banded with narrow brown lines, instead of being uniform pale rufo-fulvous. The two outer pairs of rectrices in $C$. affinis are throughout pure white ; in these examples of C.griseatus the inner webs of the basal third are pale ferruginous banded with brown.

ऽ. Wing 6.37 inches, tail $4 \cdot 0$, middle toe 0.75 .

19. Cacomantis merulinus (57).

[San Mateo. $a, \delta$ : iris yellow?; beak very dark brown; feet dirty ochreous; claws black. $b, \sigma^{*}$ : iris pale reddish; legs light chrome-yellow; claws black. $c$, $\delta^{0}$ : iris pale reddish; bill black; legs ochreous yellow ; nails black ; interior of gape red.]

20. Eudynamis mindanensis (61).

[Monte Alban. $\delta$ : iris crimson; bill greyish-green; legs dark lead-grey ; nails black.]

\section{Dasylophus superciliosus (62).}

[Monte Alban. $a, \delta$ : iris pure chrome-yellow; orbital skin and base of beak fiery orange; bill pale green; legs greenish chrome; claws dark grey. $b, \rho$ : iris chrome-yellow ; orbital skin orange; bill pale green, deep orange at base; legs yellow, tinged green on tarsus ; nails grey.]

Sexes alike.

\section{Lepidogrammus cumingi (63).}

[Monte Alban. $a, \sigma^{*}$ : iris crimson ; orbital patch ditto; bill horn-yellow; legs grey. $b, \delta^{*}$ : iris and orbital skin crimson; bill horn-yellow : legs and feet light grey. $c, \delta$ : iris and orbital skin crimson; bill horn-yellow; legs dark lead-grey. $d, q$ : iris and orbital skin crimson; bill horn-yellow ; legs and feet grey.]

Sexes alike.

\section{Centrococcyx viridis (64).}

[Monte Alban. $a, \delta$ : iris crimson; bill black; legs dark leadgrey. $b, \quad$ o juv. : iris crimson; bill and claws black; legs darkest shade of lead-grey.

San Mateo. $c$, $q$ : iris bright crimson; bill black; legs leadgrey; claws grey-brown. $d$, $q$ juv. : iris brown; legs dark-grey; beak lead-colour.]

Mr. Everett sends a series of seven individuals, four in adult and three in immature plumage. The dimensions of the male and female are alike; and this is the case in a larger series obtained by Dr. B. Meyer (l. c.). Count Salvadori (Ucc. Borneo, p. 70) has united the larger C. affinis (Horsf.) with the smaller C. javanensis (Dumont), on the ground that they respectively represent the two sexes of the 
same species. If this is correct, $C$. affinis is an exception to the rule of equality in size which prevails among all the other known Asiatic species of this genus. Moreover Bernstein has shown that the two Javan birds differ in their anatomical structure (conf. Walden, Trans. Zool. Soc. viii. pp. 56, 60).

\section{Buceros hydrocorax (66).}

[Monte Alban. $\delta$ : iris red; bill red; nails dull black; orbital skin yellow ; feet brownish red.]

The whole of the back and shoulders of the two examples obtained by Mr. Everett are smeared with an olive-yellow powder, seemingly taken from the oil-glands at the root of the tail. Mr. Elliot (Monogr. Bucerotidæ, pt. ii.) countenances the erroneous statement of the older authors that this Hornbill also inhabits the Moluccas.

\section{Penelopides manille (69).}

[Monte Alban. $\sigma$. iris crimson; orbital skin and base of mandible white; bill dark brown; the casque transparent horn-brown; the oblique bars on the maxilla ochre-yellow; feet and nails dull black; fruit in the gizzard.]

Mr. Sharpe (t. c. p. 309) identifies a Cataguan example of this genus in the British Museum with $P$. panini. If the identification and locality are correct, both species inhabit the island of Luzon.

\section{Lanius nasutus (70).}

[San Mateo. $a, \delta^{*}:$ iris orange-brown; bill, legs, and nails black. $b, \delta^{*}$ : iris pale orange-brown; bill, legs, claws black. $c$, $q$ : iris warm brown; bill and legs black.]

The four examples sent by Mr. Everett are in mature plumage. They are difficult to separate from the grey-backed form of India, L. nigriceps. The only apparent difference is, that in the Luzon bird the rufous of the uropygium and upper-tail coverts is not so bright, and that the grey on the back extends lower down. Dimensions about equal.

\section{2\%. Lanius Lucionensis (72).}

[San Mateo. $a, \delta^{*}$ : iris dark-brown; bill purplish leaden; legs dark bluish grey; claws black. $b$, 0 : iris dark brown; bill purplish leaden; legs bluish; claws dark brown. $c$, $q$ : iris dark brown; legs dark lead; claws black; bill purplish brown. 7

The two examples marked $q$ have the cheek-stripe brown, not black; and the pectoral feathers and upper tail-coverts are edged with brown.

\section{Artamus leucorhynus (73).}

[San Mateo. $a, \delta$ : iris dark brown; bill whitish blue, tipped black; legs darkest lead-grey. $b, \sigma^{*}$ : iris chocolate; bill pale bluish; feet and claws black. $c, \delta$ : iris dark brown; bill palebluish-grey, tipped black; legs darkest lead-grey; claws black. $d, q$ : iris dark brown; bill pale whitish blue, tip black; legs dark leaden.] 
29. Graucalus striatus (74).

black.

Monte Alban. $a, \delta^{*}$ : iris pale lemon-yellow ; bill, legs, and claws black.]

San Mateo. $\quad b, \delta^{*}$ : iris pure lemon-yellow ; bill, legs, and claws

Two examples in uniform plumbeous plumage.

30. Volvocivora? Cerulescens (75).

[Monte Alban. $\sigma^{*}$ : iris dark brown; bill, legs, and claws jet-black.]

In full jet-black plumage.

31. Lalage dominica (76).

[San Mateo. $a$, o . iris dark brown; bill black. $b$, $q$ : iris dark brown; bill and nails black; legs blackish-grey. $c$, $q$ : iris dark
brown; legs plumbeous.]

32. Dicrurus balicassius (80).

[Monte Alban. $a, \delta^{*}$ : iris crimson; bill, legs, and nails, black.

$b$, + : iris crimson; bill, legs, and claws, black.]

33. Philentoma cyaniceps (82).

[Monte Alban. $a, \delta^{*}$ : iris rich dark brown; bill black; legs purplish brown. $b, \sigma^{*}$ : iris crimson; bill black; legs and feet

34. LeuCocerca nigritorquis (83).

[San Mateo. $\delta$ : iris very dark brown; legs black; claws black.]

35. Cyornis Philippinensis.

Cyornis philippinensis, Sharpe, $t$. c. p. 325 .

Cyornis banyumas (84 partim). [Monte Alban. $\sigma^{*}$ : iris dark chocolate-brown; bill black; legs
light brown.]

Five examples of a species of the genus Cyornis obtained at Monte Alban by Mr. Everett are distinguishable from $C$, banyumas, ex Java, by having the abdomen, vent, and under tail-coverts white and not rufous, and the rufous of the breast paler. Above no difference is discernible. A Zebu bird collected by Dr. B. Meyer (t.c. no. 84) differs from the Luzon in being of a darker shager $t$. especially on the head, and in having the shade of blue above, feathers and the wing-coverts darker bu the frontal and superciliary not separable from the type of $C$. The Luzon examples are Museum.

36. НуротнYмis AZUREA (85).

[Monte Alban. a, o : iris chocolate-brown; bill blue, tip black interior of gape pale yellow-green; legs lead-blue; nails black. $b, \sigma^{*}$ : iris dark brown; bill blue, tip black; legs lead-blue; nails black. $c$, $\delta$ : iris dark brown; blackish blue; legs lead-blue. $d$, $f$ : iris dark chocolate-brown; bill and nails black; legs dark grey.] 


\section{Butalis manillensis (86)?}

[Monte Alban. $\delta$ : iris dark brown; legs and claws black; bill dark vandyke brown, nearly black.]

A single example of a species of grey Flycatcher is sent by $\mathrm{Mr}$. Everett, which, while resembling B. griseosticta, Swinh., still cannot be said to belong to that species. It is a larger bird with a wing measuring $3 \cdot 56$. 'The bill is narrower and longer, more like that of B. grisola. Above the plumage is of a paler purer grey and not grey-brown. The wing-lining and axillaries are grey rather than pale rufous. With doubt $\mathbf{I}$ refer this bird to B. manillensis, Bp.; for he states that the Manilla race is smaller than $B$. grisola, while this Luzon bird exceeds the European species in its dimensions. Mr. Sharpe (t. c. p. 326) identifies an example obtained in Panay by Dr. Steere with B. griseosticta ${ }^{1}$.

\section{Hirundo gutturalis (88).}

[San Mateo. $a, \sigma^{0}$ : iris and feet dark brown. $b$, $q$ : iris brown ; bill, feet and nails black.]

\section{BRoderipus ACRORHYNChUS (90).}

[San Mateo. a, o : iris pale purplish-brown; bill dull pale crimson; legs dark lead-grey; claws black. $b, \delta$ : iris white ; bill dull pale crimson; feet bluish-lead; claws black. $c, \sigma^{\top}$ : iris yellow; bill pale dull crimson; feet dark grey. $d, \delta^{*}$ : iris purple-grey, outer ring white; bill pale crimson; legs lead-grey. $e, q$ : iris purple grey ; bill pale dull crimson; legs lead-grey.

Monte Alban. $f$, o $o^{*}$ iris purple-grey ; bill white, tinged crimson; legs lead-grey ; claws blackish.]

Ten adult examples were obtained by Mr. Everett, seven males and three females. All the males have the middle pairs of rectrices jet-black, tipped with yellow. The same feathers in the females are washed with yellow; and the body plumage is not of so golden a tint.

\section{Megalurus palustris (96).}

[San Mateo. $\delta^{0}$ : iris orange-brown; bill black; mandible leadgrey ; legs horn-brown; claws dark ditto.]

Identical with individuals from Burma, Assam, Sylhet, Munipur \&c. ; but I have not been able to compare it with typical examples. The Bengal (Philippine?) example, described by Pucheran (Archives du Mus. vii. p. 342) as being one of the types of Gracula caudata, Cuvier, must belong to this bird and not to the Timalia chatarcea, Frankl., of India; and, judging from Pucheran's remarks, the Javan bird, Malurus marginalis, Reinw. (=Megalurus palustris, Horsf.), although very close, appears to differ from the Indian bird. There is good reason to doubt the occurrence of Timalia chatarcea, Frankl.

1 Since these remarks were in print, I have had the advantage of perusing M. Oustalet's observations on the type specimen of $B$. manillensis, Bp., in the Paris Museum (Ois. de la Chine, p. 123), whereby it appears that that gentleman is also of opinion that $B$. manillensis is distinct from $B$. griseosticta. 
(= Gracula caudata, Cuv., apud Blyth), in the Philippines. Both Jerdon and Blyth appear to have been misled into identifying Franklin's bird with the Cuvieran type by some remarks of Lafresnaye's (Mag. Zool. 1st series, Timalia). Lafresnaye gave Franklin's diagnosis (P.Z.S. 1830-31, p. 118) and wrote that T'. chatarcea "nous a paru être le même oiseau que celui intitulé au Musée, Gracula caudata (Cuvier)." Lafresnaye described a bird in his collection and identified it with the type in the Paris Museum (said to have been obtained in Bengal by Dussumier in October 1820, but having, when Pucheran examined it, "Manilla" written on its label). And Lafresnaye's description ( $l . c$.$) , and certainly Pucheran's of the type$ (already alluded to), will not apply to Franklin's bird. Blyth (Ibis, 1867$, p. 6$)$, in the belief that T. chatarca, Franklin=G. caudata, Cuvier, mentioned, on Pucheran's authority, that it was found in the Philippines; and I inadvertently gave Franklin's species a place in my list of Philippine birds (t. $c$. no. 97) although I stated that Indian anthors seemed to have been somewhat hasty in identifying $T$. chatarcea with $G$. caudata, Cuvier. T. chatarca may, for the present, be safely eliminated from our lists of the Philippine fauna.

\section{Megalurus ruficeps. (Plate LXXII.)}

Megalurus ruficeps, Tweeddale, Ann. \& Mag. N. H. ser. iv. vol. xx. p. 94 (1877).

ㅇ. Lower surface white, faintly tinged with cream-colour on the breast. Flanks pale earthy brown. Under tail-coverts pale dingy isabelline rufous; thigh-coverts of a more decided rufous. Space before the eye and supercilium, passing well behind the eye, greyish white. Forehead, head, and nape, pure bright uniform rufous. Back olive-grey, each feather broadly centred by a longitudinal stripe of brown. Uropygium and upper tail-coverts uniform olive-grey. The base of the long and lax uropygial feathers pure dark grey, the tips only being olive-grey. Rectrices above dull ruddy brown, obsoletely barred with narrow brown lines. Quills brown, externally margined with ferruginous olive. Lesser wing-coverts olive-grey; greater tinged with ferruginous.

Wing $2 \cdot 75$ inches, tail $5 \cdot 25$, tarsus $1 \cdot 0$, culmen $0 \cdot 56$.

[Monte Alban. 9 : light clay-brown; bill brown, lower half grey; legs and feet whitish.]

\section{Ixus Golavier (99).}

Monte Alban. $a, \delta^{*}$ : iris bright brown; bill black; legs dark brown. $b, \delta$ : bill, legs, and nails black. $c$, $q$ : bill and legs black; iris brown.

San Mateo. $d$, $q$ : iris dark brown; bill black; legs dark grey, almost black.]

All Mr. Everett's specimens (a series of eight) of this species have the ear-coverts dark brown, the only character apparently which separates it from $I$. analis. The plumage of the two sexes does not differ. 
43. Hysipetes phillippinensis (102).

[San Mateo. a, $\delta^{*}$ : iris burnt-sienna brown; bill black; legs dark sepia-brown. $b$, $q$ : iris burnt-sienna brown; bill black; legs dark plumbeous.

Monte Alban. $c$, $\delta^{*}$ : iris burnt-sienna brown; bill black; legs and nails blackish grey.]

44. Monticola solitarius (103).

[Monte Alban. $a$, o : iris chocolate; bill, legs, and claws black ; $b$, $\delta$ : iris dark brown; bill and nails black; legs blackish brown.]

Lower breast and abdomen almost pure dark rufous, a few of the blue and rufous feathers with albescent tips. Above with albescent tips and subterminal black marks.

45. Pratincola caprata (104).

[Monte Alban. $\quad$ : : iris dark brown; bill, legs, and claws black.]

46. Copsychus mindanensis (106).

[San Mateo. a, $\delta$ : iris chocolate; bill, legs, and claws black. $b$, $\delta$ : iris dark brown; bill black; legs and claws very dark brown.

Monte Alban. $d$, $q$ : iris chocolate-brown.]

The adult female is dark glossy bluish-grey above. The chin, cheeks, throat, and breast a purer dead grey. The white of the abdomen somewhat sullied with rufescent.

\section{Corydalla lugubris (117).}

[San Mateo. $a, \delta^{*}$ : iris dark chocolate-brown; bill vandyke brown, lower half yellowish ; legs ochreous yellow ; claws pale grey brown. $b$, 9 : ? iris dark chocolate; bill sepia-brown; mandible yellow-brown; legs and feet brownish ochre-yellow; claws pale brown.]

\section{Anthus maculatus.}

Anthus arboreus, var. japonicus, Schlegel, Faun. Jap. pp. 58, 139, t. xxiii., "Japan" (1842).

Anthus maculatus, Hodgs. Gray's Zool. Misc. p. 83 (1844); Blyth, J. A. S. B. 1847, p. 433 : conf. Brooks, Str. F. 1876, p. 278. Dendromanthus maculatus (Hodgs.), Blyth, Cat. Calc. Mus. p. 135. no. 753 .

Pipastes agilis (Sykes), Gould, B. of As. pt. xvii. t. - (April 1, 1865).

Pipastes maculatus (Hodgs.), Blyth, B. Burm. no. 224.

[Monte Alban. $\delta$, shot on the ground in the forest.]

49. Parus elegans.

Machlolophus elegans (118).

[Monte Alban. o : iris dark brown; bill black; legs grey.]

This is a true Parus and not a Machlolophus as was suggested by Mr. Blyth. 
50. Calliope camtschatkensis (107).

[Monte Alban. $\delta$ : iris dark brown; bill black, grey at base ; legs and feet purplish grey.]

\section{Phylloscopus borealis.}

Phyllopneuste borealis, Blasius, Naumannia, 1858, p. 313.

Phylloscopus magnirostris, Blyth, apud Blyth, Ibis, 1870, p. 168 ; Walden, $t$. c. no. 109.

[Monte Alban. $a, \delta^{*}$ : iris brown; maxilla dark brown ; mandible yellow ; legs and claws pale clear brown.

San Mateo. $b, c$ : iris dark brown; legs raw-sienna brown; maxilla dark horn-brown; mandible horn yellow. $c$, ㅇ : iris brown; legs yellow-brown; bill brown; lower half yellow.]

As I anticipated ( $t$. c.), the Phylloscopus from the Philippines, identitied by Mr. Blyth with $P$. magnirostris, proves to belong to $P$. borealis. Four examples were obtained by Mr. Everett, in the month of February. The first alar bar is almost obsolete; but Mr. Dresser has no doubt that they belong to $P$. borealis, and they agree well with my own series of that species.

\section{Orthotomus derbianus (112).}

[Monte Alban. $a$, $\delta$ : iris bright clay-brown; bill sepia; the mandible pale grey; legs and nails pale clear brown. $b, \sigma^{*}$ : iris bright clay-brown; bill dark brown; mandible grey; legs very pale transparent brown.]

Moore accurately described this species of Orthotomus; but in the figure the wings are coloured of too vivid a green. The wings are yellow-green.

\section{Budytes viridis (114).}

[Monte Alban in February.]

\section{Calobates melanope (115).}

[Monte Alban. $a, \sigma^{*}$ : iris brown; bill light vandyke brown; legs and feet pale transparent brown; nails vandyke brown. $b, q$ : iris brown; bill dark lead-grey; legs pale transparent brownish grey. $c$, $\uparrow$ : iris brown; bill dark brownish grey; legs very pale clear brown ; claws vandyke.]

Average length of rectrices in five examples, $3 \cdot 87$.

\section{Motacilla ocularis.}

Motacilla ocularis, Swinhoe, Ibis, 1860, p. 55 ; P. Z.S. 1870 , pp. 129, 130, woodcuts.

[Monte Alban. o , March : iris, bill, and legs dark brown.]

A single example with a grey back, a few dark feathers on the vertex, and a black pectoral plastron; forehead and a broad space over the eye white; a line passing from base of bill through the eye black. 


\section{Diceeum Rubriventer.}

Pipra papuensis, Gm. S. N. i. p. 1004. no. 21 (1788).

Dicøum rubriventer, Lesson, Tr. p. 303 (1831).

Dicaum retrocinctum, Gould, B. As. xxvii. t.-, inf.; Walden, $t . c$. no. 120. partim; conf. Salvadori, Ann. Mus. Civ. Genoa, viii. p. 509.

[Monte Alban. $\sigma^{*}$ : iris bright brown; bill glossy black; legs and nails dark brown.]

Not to be distinguished from Zebu examples.

57. Dicaum xanthopygium. (Plate LXXIII. fig. 1.)

Dicaum xanthopygium, Tweeddale, Ann. \& M. N. H. ser. iv. vol. xx. p. 96 (1877).

o. Above, cheeks and wing-coverts dark bluish slate-grey. An isolated dorsal patch crimson. Uropygium yellow. Chin, throat, and upper part of breast yellow. Remainder of breast, abdomen, and flanks orange. Ventral region, thigh-coverts, and under tailcoverts yellow tinged with green. Rectrices and quills dark brown; the primaries narrowly margined with white, the secondaries with olive-green.

Wing 1.96 inch, tail $1 \cdot 06$, tarsus 0.50 , culmen 0.38 .

[Monte Alban. $0^{*}$ : iris dark brown; legs dark greyish-brown; bill black.]

This is a second Philippine representative form of D. trigonostigma, and, as an example of progress in the variation of a species, is interesting. It, together with $D$. dorsale, Sharpe, and the Malayan species form a small subgroup, the Luzon bird being hardly distinguishable from D.trigonostrgma, as seen from above, and from the Panay species when seen from below. Is the Negros habitat of $D$. trigonostigma of Mr. Sharpe's list ( $t . c$. p. 352. no. 171) reliable?

58. Myzanthe Pygmea (121).

[Monte Alban. $a, \delta^{*}$ : iris dark brown; bill and legs black. $b, \delta^{*}$ : testes greatly enlarged.]

\section{Arachnechthra jugularis (123).}

[Monte Alban. $\delta$ : iris light brown ; bill, legs, and nails jet-black.]

60. Corvus philippinus (125).

[San Mateo. $a, \delta$ : iris dark brown; bill and legs black. $b$, $q$ : iris pale wood-brown; bill, legs, and claws black.]

Three of the four examples sent by Mr. Everett have the wing an inch and a quarter to a half shorter than that of the fourth individual. This last is in full glossy purple-black plumage, while the three with short wings are in a state of transition from brownish unglossed black to purple-black. They belong to C. brevipennis, Schlegel.

61. Acridotheres cristatellus (126).

[Monte Alban. a, $\delta^{t}$ : iris yellow; bill pale yellowish; legs dark brownish ochre-yellow; nails black.

San Mateo. $b, \delta$ : iris golden yellow; bill yellow-white; legs 
chrome; claws horn-brown. $c$, $q$ : iris Indian yellow; bill light greenish-yellow ; legs dull orange; claws brown.]

62. Sarcops calvus (129).

[Monte Alban. $a, \delta^{*}$ : iris bright brown; bill and legs black; bare skin white tinged with pink.

San Mateo. $b, \sigma^{*}$ : iris rich chocolate-brown; bill, legs, and claws black. $c$,, : iris rich warm brown; bill black; feet and claws sooty brown ; bare skin white tinged dull crimson.]

63. Munia Jagori (132).

[San Mateo. $q$ : iris red-brown; bill pale bluish-grey; legs darker grey.]

\section{OXYCERCA JAGORI (134).}

[San Mateo. $\delta$ : ?, iris Indian red; bill dull blue; legs bluegrey.]

65. Oxycerca everetti. (Plate LXXIII. fig. 2.)

Oxycerca everetti, Tweeddale, Ann. \& Mag. N. H. ser. iv. vol. xx. p. $96(187 i)$.

$\sigma$ and $q$. Chin and throat dark brown ; breast, flanks, and thighcoverts warm nutmeg-brown. Abdomen and vent pure white, some of the lower breast-feathers being marked with brown, and some of the flank-feathers being white on their inner webs, brown on their outer, and with white shafts. Under tail-coverts very dark brown or black. Above, wings and coverts brown, each feather, except the frontal and upper tail-coverts, having a conspicuous pure white central line along the shaft, very prominent on the wing-coverts; some of the upper tail-coverts tipped with ochre. Rectrices brown, the middle pair broadly margined, the laterals less so, with yellow and greyish yellow. Inner edges of the quills pale rufous seen from underneath.

Wing 1.87 inch, tail 1.75 , tarsus 0.56 , culmen 0.38 .

[Monte Alban. $a, \delta^{t}$ : iris Indian red; bill black; mandible leadgrey; legs dark grey. $b$, $q$ : iris Indian red; bill black; mandible and legs grey.]

This is a representative form of Munia leucogastra, Blyth, but quite distinct, being of a warm nutmeg-brown colour, and not dark sootybrown, and having the white striæ of the upper plumage much more boldly defined.

66. Osmotreron axillaris (136).

[Monte Alban. $a, \delta^{*}:$ iris bluish green; feet greyish green; nails grey; bill light green, base dark red. $b, q$ : iris pale seagreen ; bill green; base of maxilla red; feet whitish green; nails grey. $c, q$ : iris light bluish-green; bill green; base of maxilla red; feet greyish green; nails grey.]

67. Phabotreron leucotis (140).

[San Mateo. a, ㅇ: iris grey; bill black; feet dull crimson; 
claws brown. $b$, 우 : iris purplish-grey; bill black; orbital skin dull bluish ; feet dull crimson. $c$, + : iris purplish grey ; bill black; feet crimson ; nails horn-grey.

Monte Alban. $d, \delta$ : iris purple-grey; bill black; feet bright carmine ; claws brown. $e, \delta^{*}$ : iris brown ; bill black ; feet carmine.]

68. Turtur dussumieri $(14 \pi)$.

[Monte Alban. $a, \sigma^{*}$ juv. : iris dark ochre-yellow; bill greyish black; feet dull crimson. $b, \delta$ juv. : iris dark ochre-yellow; bill greyish-black; legs purple-brown. $c, \sigma^{*}$, pairing : iris ochreous orange; bill greyish-black; feet dull crimson. $d$, $ᄋ$ : iris brownish orange; bill black; nails brown; feet carmine; paddy and maize in the crop.]

The example marked a $q$ differs from the males, and agrees with the description given $(l . c$. $)$ of a female ex Luzon obtained by Dr. B. Meyer. Two of the males are immature, the nuchal band not being completed, and all traces of the vinous colouring of the nape being wanting.

\section{Phlogenas luzonica (149).}

[Monte Alban. $a, \delta^{*}$ : iris greyish violet; bill black; legs dull crimson; nails grey. $b, q$ : iris light greenish-brown; bill black; legs carmine. $c, q$ : iris pale greyish-violet; bill greyish black; feet dull crimson ; nails dark grey.]

The female is slightly smaller; and the pinkish-red colouring of the abdomen is much deeper in the male.

70. Chalcophaps indica (150).

[San Mateo. $a, \delta^{\text {: }}$ : iris dark brown; legs dull crimson; bill orange-red.

Monte Alban. $\quad b, q$ : iris dark brown ; bill orange-red; feet dull crimson. $c, \sigma^{*}$ : iris chocolate-brown; bill orange-red, base crimson; feet dull crimson.]

\section{Geopelia striata (152).}

[San Mateo. $a, \delta^{*}$ : iris white; bill dull bluish; orbital skin white tinged blue; legs dull crimson. $b, q$ : iris white; legs dull purple ; bill dull blue ; orbital skin ultramarine. $c$, $q$ : iris whitishyellow; bill blue, almost black; legs dull crimson; orbital skin pale ultramarine.]

These examples in no respect differ from Malaccan and Javan individuals and others from the island of Madura. Neither by their dimensions nor colouring can the sexes be distinguished.

\section{Turnix ocellata (156).}

[Monte Alban. $a, \delta^{*}$ : iris yellowish white; bill greenish; legs greenish-yellow; nails grey. $b, q$ : iris pale yellow; bill light greenish-yellow; legs the same. $c$, $q$ : iris white; bill grey tinged greenish ; legs light yellow; nails grey.]

A very fine species. The female is fairly depicted by Meyen; the 
male, besides being much smaller, differs in having the throat almost white, each feather being but slightly tipped with brown.

$\begin{array}{ccc}\text { Wing. } & \text { Tarsus. } & \text { Culmen. } \\ \text { o } 3.87 & 1.00 & 0.75 \\ \text { o } 4.25 & 1.06 & 0.81\end{array}$

73. Turnix fasciata.

Hemipodius fasciatus, Temm., Pig. \& Gallin. iii. pp. 634, 757, "Philippines" (1815); Walden, t.c. p. 225.

Monte Alban. $a, \delta^{*}$ : iris white; bill blackish, base yellow; legs light greenish-yellow. $b, \sigma^{*}$ : iris white; bill greenish yellow; culmen black; legs and feet light greenish-yellow; nails grey. $c$, $\sigma^{*}$ : iris white; bill greenish yellow; legs yellowish-green; nails brown. $d$, 오 iris ochreous yellow; bill and legs yellow tinged green, the bill clouded with blackish green. $e$, $q$ : iris white; bill greenish chrome, the culmen clouded; legs greenish chrome.]

Mr. Everett has sent six specimens of a species of Turnix which agree well with Temminck's description. They are at once distinguishable from $T$. pugnax, ex Java, by the uniform broad light rufous patch on the nape, and by being much smaller, but otherwise are nearly allied. The abdomen in both sexes is white. From T. rostrata they differ still more.

$\begin{array}{ccc}\text { Wing. } & \text { Tarsus. } & \text { Culmen. } \\ \text { o } 3.00 & 0.87 & 0.50 \\ \text { ㅇ } 3.25 & 0.93 & 0.60\end{array}$

74. Charadrius fulvus (159).

[San Mateo. $a, o^{*}:$ iris chocolate-brown; bill black; legs pale lead-grey. $\quad b, q$ : iris brown; legs light lead-grey.]

\section{Agialitis dubia (162).}

[Monte Alban. $a, \delta^{*}:$ iris warm chocolate-brown; orbital ring pure orange; bill black, base orange; legs grey; nails black. $b, \delta^{*}$ : iris brown; bill black; legs ochreous yellow; nails black. $c$, + : iris dark brown; bill black, base yellowish; legs purplish grey; breeding. $d$, o : iris dark brown; bill and nails black; legs

Seven examples, in various stages of plumage, of what is undoubtedly typical $\boldsymbol{E}$. dubia (Scop.) have been sent by Mr. Everett. A comparison made with these Luzon individuals and others of socalled $\boldsymbol{E}$. curonica $(\mathrm{Gm}$.) and $\boldsymbol{A}$. minuta (Pall.), apud Jerd., from Europe and Asia (conf. Walden, Tr. Z. S. viii. p. 89), leaves me no other conclusion than that they all belong to one species. In dimensions examples vary considerably; but intermediate links occur uniting the smaller with the larger races. In markings and colouring there is little difference, and the proportionate length of the tertiaries to the first primary is very variable in birds even from the same locality. The species described by Mr. Blyth (Ibis, 1867, p. 164, no. 849) as $\boldsymbol{E}$. philippensis, vera, is $\boldsymbol{E}$. peronii (Tem.).

Proc. Zool. Soc.-1877, No. XLVI. 
Dimensions.

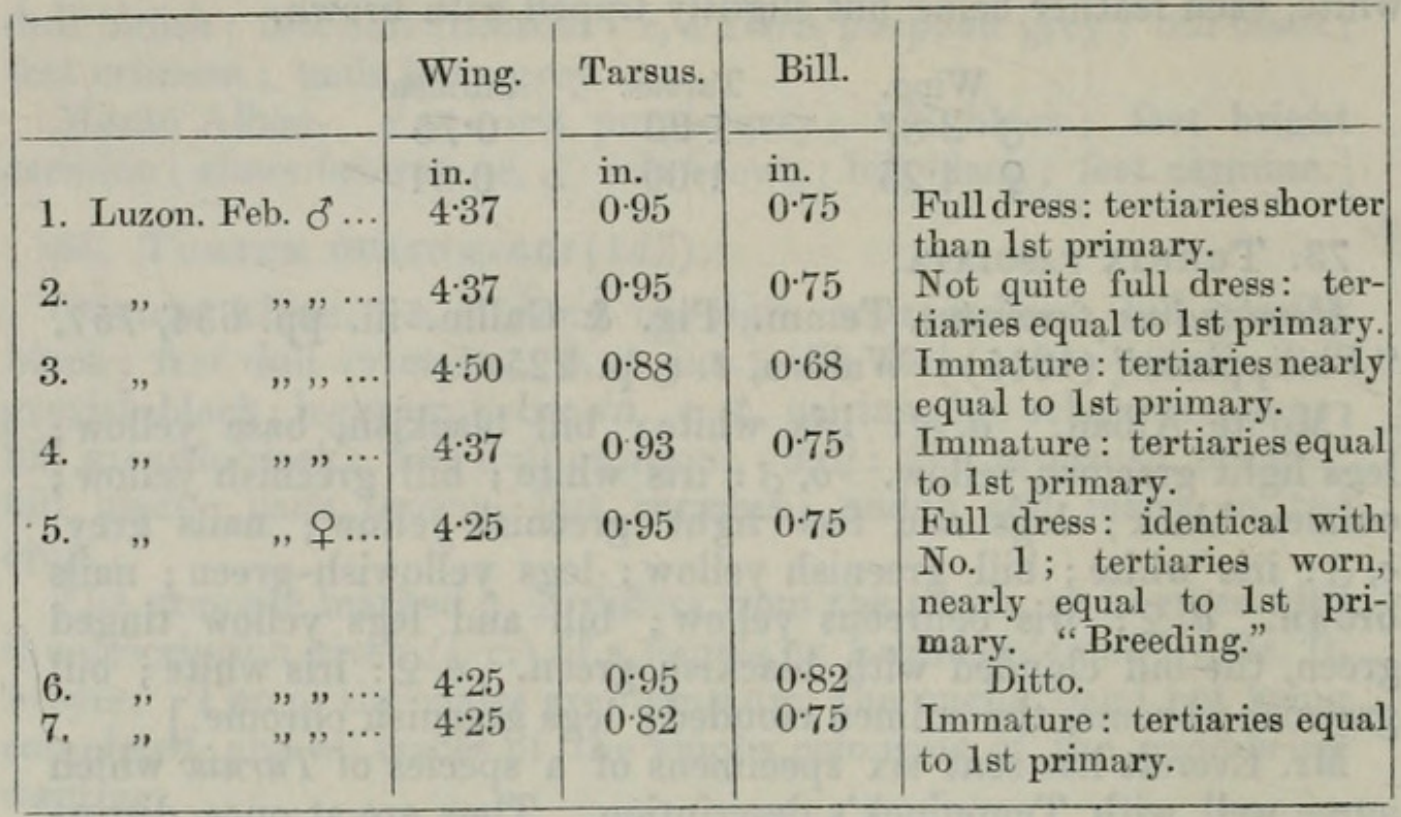

76. Gallinula chloropus (169).

[Monte Alban. $\delta$ : iris bright blood-red; bill bright greenishyellow; legs and feet grass-green.]

\section{Amaurornis olivacea (176).}

[Monte Alban. $a, \delta^{*}$ : iris bright blood-red; bill dark green ; feet and legs yellow-brown. $\quad b, q$ : iris bright blood-red; bill light green; legs and feet light brown.]

\section{Hypotenidia torquata (177).}

[Monte Alban. $a, \delta^{*}$ : iris bright blood-red ; bill black ; feet and legs brown. $b, q$ : iris bright Indian-red; bill black; legs sepiabrown. $c, q$ : iris bright red; bill black; legs very dark leadgrey.]

The sexes do not differ in their dimensions or plumage. The pectoral band appears when the bird is reaching maturity. The blackbarred pectoral feathers become first suffused with olive-green or with rufous, the black and white bands showing through. These bars then become obliterated and the feathers become uniform olivegreen, dashed with dark rufous. Ultimately the pectoral band becomes uniform chocolate-brown.

79. Hypotanidia philippensis (178).

[Monte Alban. $\delta^{*}$ : iris Indian red ; bill warm brown; legs, feet, claws, light greyish-brown. February.]

The specimens sent by $\mathrm{Mr}$. Everett, three males, are typical. In all, the black bands of the breast and abdomen are not very decidedly pronounced, though well marked on the flanks. In two the pectoral band is just indicated by the tips of some of the feathers being tinged with pale rusty-fulvous. In the third the white bands are coloured with rusty fulvous, but the black bands show through. In the ex- 
ample which has the pectoral band least developed the nape is most rufous, and this is the case in a Celebean individual without a trace of a pectoral band, the nape being pure bright rufous, and in others from Queensland. The dimensions of birds from all three localities hardly vary.

80. Rhyacophilus glareola (182).

Shot in February and March.

81. Tringoides hypoleucus (183).

[Monte Alban. $a, \delta^{*}$ : iris brown; bill dark vandyke brown; legs greenish grey; nails black. $b, \delta^{*}$ : iris brown; bill and nails black; legs greenish lead-grey.]

Shot in February and March.

82. Gallinago scolopacina (187).

[Monte Alban. $a, \delta^{\star}$, February: iris brown ; legs greenish grey ; nails black.]

83. Rhynchea capensis ( 189 ).

[Monte Alban. ơ, February.]

84. Ardetta cinnamomea(192).

[San Mateo. $a, o^{\star}$ (adult): iris bright yellow; legs and feet bright olive-green; bill yellow shaded with olive-brown on the culmen; February. $b, \sigma$ (not mature): iris bright yellow; bill greenish yellow, culmen to apex darkened with greenish brown; legs yellowgreen; soles of feet yellow; claws light brown. $c$, $q$ (immature); iris golden yellow ; legs and feet bright olive-green; bill greenishyellow at base ; culmen dark olive-brown ; February.]

85. Herodias garzetta (195).

[Monte Alban. + , March : iris bright yellow ; bill black, base yellow; legs black; feet greenish-yellow dotted with black; claws dark brown.]

Two examples are sent by $\mathrm{Mr}$. Everett shot in March, and both marked $q$. One is in full breeding-plumage with two long occipital plumes, a fully developed pectoral tuft, and a long dorsal train. In the other these appendages are absent, the bill being black in both. In dimensions they agree; and they belong strictly to the race named Ardea nigripes by Temininck.

Wing $10 \cdot 25$ inches, tarsus $3 \cdot 50$, culmen $3 \cdot 0$.

86. Butorides javanica (197).

[Monte Alban. $q$ : iris golden ; bill black; lower half, cere, and orbital skin light yellow; legs green; soles orange; nails brown. March.]

Immature. 
3. Remarks on Felis tigrina, Erxl., and its Synonymy. By D. G. Elliot, F.R.S.E. \&c.

[Received June 28, 1877.]

Erxleben, in his 'Systema Regni Animalis,' published in 1777, described a Cat from Guiana, Cayenne, \&c. as Felis tigrina, characterized as having a long tail, fulvous fur on the body spotted and striped with black, beneath white. This animal is much smaller than $F$. pardalis, and differs also in style of its marking, rather difficult to explain in words; but generally the black is more inclined to take the form of spots than lines or stripes. There is no doubt whatever that the two belong to very different and distinct species.

In 1820, in the 'Histoire Naturelle des Mammifères,' MM. Cuvier and Geoffroy St.-Hilaire described another Cat of this form as Felis mitis, from Brazil, characterized by having a tail about half the length of the body and head, with a general buff colour, and spotted irregularly with black, the centres of the spots of light buff.

In 1826 Prince Maximilian of Neu-Wied, in his 'Beiträge zur Naturgeschichte von Brasilien,' also described a species of Felis, distinguished by having the tail as long as the body. In other respects, such as the general colour of the fur, together with the shape, disposition, and hue of the spots, it does not vary more from the two animals mentioned above than do individuals of any species of Spotted Cats from each other. With the exception of Erxleben, who gives a general habitat for his animal, such as "America Australis," citing the Cayenne Cat of Pennant, and the Tiger Cat of Guiana, Bauer, as synonymous, the authors mentioned ascribe Brazil as the habitat of their respective species. For a long time the animals called by these different names, bestowed upon them by their describers, gave me a great deal of trouble, as I strove to find recognizable and permanent differences by which the species, if they really were such, could be discriminated.

The late Dr. J.'E. Gray, in his papers on the Felidæ, especially in his 'Catalogue of the Carnivorous, Pachydermatous, and Edentate Mammalia,' although he states that the three species vary greatly in the size, form, and disposition of the spots (to which he might have added colour), endeavoured to keep the three apart by the "kind" and colour of the fur and the colour and length of the tail. Thus $\boldsymbol{F}$. macroura and $\boldsymbol{F}$. mitis have soft bright fulvous fur and tail distinctly ringed; and $F$. tigrina has a harsher grizzled fur, and the tail marked with a series of dark spots, not forming distinct rings. In regard to the distinction given to the fur as it feels to the touch, I may not have the sensitiveness necessary to enable me to appreciate the character ; but the fur of all the animals belonging to this particular type of Felis appears to me to have a similar texture, and I hardly consider that the softness or harshness of the hair will be sufficient to render the animals specifically distinct or to enable them to be recognized by that character. 
F. macroura, as its name implies, has for the most part relied upon the length of its tail to establish its claim to a distinctive rank; and so far as I can discover, leaving aside some slight differences of colour, $\boldsymbol{F}$. mitis must be recognized by having a tail intermediate in length between $F$. macroura and $F$. tigrina. Although I have carefully examined and compared specimens of the alleged species in most of the large collections in Europe aud also in that of the Smithsonian Institution at Washington, I had been utterly unable to find any reliable character to distinguish them from each other. On a recent visit to London (one of the chief objects of making which was to further investigate this subject) in company with my friend Mr. E. R. Alston, who was occupied with the Felidæ inhabiting Central America, I examined anew the entire collection of these so-called three species, consisting of skins, mounted specimens, and skulls, contained in the British Museum. These are, in all, nineteen specimens, coming from various localities between Honduras on the north, and Paraguay on the south.

As the length of tail was a principal character, especially for $F$. macroura, this member was our first consideration; and it very soon proved to be, as I had always found was the case, thoroughly unreliable; for the tails were of all possible lengths, irrespective of locality, and if arranged in a series would exhibit a gradual progression from the shortest to the longest and most pretentious. The next step was the arrangement of the spots or rings, mindful of Dr. Gray's descriptions of rings distinct and rings indistinct. Both kinds were found; in fact a third style was discovered; for, while some had tails incompletely ringed, and others tails with some perfect rings, others, again, had spotted tails without any tendency at all to form any kind of ring. No two were exactly alike, even from the same place, while others from far distant localities bore a more general resemblance to each other than some that had the same habitat. As to colour, one had but to choose the shades of buff or grey that pleased him best; for apparently all were represented, and it was difficult to find the same hue on two individuals.

The tails proving to be miserable failures in every way for specific distinction, we next turned our attention to the bodies and heads, and were at once met with the same difficulties; for the animals had as great a disregard for uniformity in the colour of their fur and in the patterns of the markings on their bodies as they evidently had for that on their tails. All hues of grey and buff were exhibited, every shape and size of spots were there, some solidly black, others with light centres and black edges, scattered about separately or coalescing and forming stripes, but without regularity of pattern, and no two examples exactly alike from any or all localities. It was very evident that if there really did exist three species there must be some other means to distinguish them; for of all the characters that had been given of the colour and style of markings, it was very evident that none were of any value whatever; and as a last resort we turned to the skulls.

Here, also, our efforts met with no better success; for variations 
also existed in these, mainly, however, in size : no two were precisely alike from any locality; and there did not exist any single reliable character that could be given by which more than one species could be established and recognized. I therefore feel no hesitation in stating that there exists but one species of Spotted Cat, commonly known as the Margay, belonging to the New World, and that the animals generally known as F. macroura, Pr. Max., and F. mitis, Cuv., are identical with it, and that these names must become synonyms of Felis tigrina. I have always found it unsafe to decide upon any species of Spotted Cat from a single specimen, unless accompanied by some trenchant character exhibited in the skull which would permit it readily to be distinguished; and this, I may remark, is very rarely to be found among the Felidæ.

All the species of Felis from both the Old and New Worlds vary so greatly in different examples that one is often tempted to believe a distinct species, perhaps a new one, is before him; and it is only in a series of examples that it can be seen how the so-called species run into each other, and that what may have appeared a strong specific character becomes of no real value whatever. The same species frequently ranges over many degrees of latitude ; and the individuals of northern regions are observed to be clothed with long thick fur as a protection against the severity of the climate, and, although presenting outwardly a very different appearance from their smooth short-coated brethren of the tropics, should not, on that account, be elevated into distinct species.

The following synonymy shows the more prominent names that should be placed under the head of $F$. tigrina.

Felis tigrina, Erxl. Syst. Regn. Anim. (1777) p. 517, sp. 11 ; Gmel. Syst. Nat. (1788) vol. i. pt. 1, p. 80, sp. 13; F. Cuv. Hist. Nat. Mamm. (1826) vol. ii. pl. 144 ; Temm. Mon. Mamm. (1827) vol. i. p. 153 ; Fisch. Syn. Mamm. (1829) p. 204, sp. 16 ; J. E. Gray, Proc. Zool. Soc. (1867) pp. 27 1, 404; id. Cat. Carn. Mamm. (1869) p. 22.

Cayenne Cat, Penn. Hist. Quad. (1781) p. 271, sp. 163.

Guigña Cat, id. ibid. (1793) p. 299, sp. 198.

Felis guigña, Molina, Sagg. Stor. Nat. Chili, (1810) p. 244, sp. 6 ; Desm. Dict. Hist. Nat. (1816) p. 114 ; Philippi, Wiegm. Arch. (1873) p. 8, tab. ii. \& iii. figs. $2 \& 3$.

Felis margay, Azara, Nat. Hist. Quad. Parag. (1838) p. 237.

Felis (Noctifelis) guigña, Severtz. Rev. \& Mag. Zool. (1858) p. 386.

Felis mitis, F. Cuv. Nat. Hist. Mamm. (1820) vol. ii. pl. 137; Azara, Nat. Hist. Parag. (1838) p. 226 ; Burm. Syst. Uebers. Thier. (1854) p. 86 ; J. E. Gray, Proc. Zool. Soc. (1867) pp. 271, 404; id. Cat. Carn. Mamm. (1869) p. 22.

Felis chati, Griff. Anim. King. (1827) vol. ii. p. 479, pl.

Felis smithii, Swains. Anim. in Menag. (1838) p. 120.

Leopardus mitis, J. E. Gray, List Mamm. Brit. Mus. (1843) p. 42 .

Felis macroura, Pr. Max. Beitr. z. Naturg. Bras. Band ii. 
(1826) p. 371; Fisch. Syn. Mamm. (1829) p. 203, sp. 12; Less. Suppl. Buff. (1847) p. 113 ; Burm. Syst. Uebers. Thier. Bras. (1854) p. 87 ; J. E. Gray, Proc. Zool. Soc. (1867) p. 271 ; id. Cat. Carn. Mamm. (1869) p. 22. 139.

Felis brasiliensis, F. Cuv. Hist. Nat. Mamm. (1828) vol. ii. pl.

Felis elegans, Less. Cent. Zool. p. 69, pl. 21.

Leopardus tigrinoides, J. E. Gray, List Mamm. Brit. Mus. (1843) p. 42 .

Panthera brasiliensis, Fitz. Sitzungsb. Akad. Wiss. Wien, (1869)

Panthera macrura, id. ibid. p. 242.

Panthera venusta, id. ibid. p. 244.

Hab. Central America southwards to Paraguay.

4. On some Points in the Visceral Anatomy of the Rhinoceros of the Sunderbunds (Rhinoceros sondaicus). By A. H. Garrod, M.A., F.R.S., Prosector to the Society.

[Received October 1, 1877.]

Our present knowledge of the visceral anatomy of the Rhinocerotidæ is confined to that of the two species Rhinoceros unicornis and Ceratorhinus sumatrensis. Professor Owen has given us, in the 'Transactions' of this Society (vol. iv. pp. 31 et seq.) an exhaustive account of the former of these animals; and in the 'Proceedings' (1873, pp. 92 et seq.) it has been my endeavour to indicate most of the important features in the latter, which, as Prof. Flower has kindly pointed out to me, were briefly described by Sir E. Home in the 'Philosophical Transactions' (1821, p. 271). On the present occasion I bring before the Society my notes on a young female of the Sondaic Rhinoceros (Rhinoceros sondaicus), which died in the menagerie of Mr. C. Jamrach, after having been in this country for a little more than half a year. It was only the skinned trunk which came into my possession. It is the nature of the mucous membrane of the small intestine which was certain to be of greatest interest; and this I am able to describe in detail.

The individual under consideration measures, stuffed, six feet two inches from the tip of the nose to the base of the tail. The tail itself is a foot long, whilst the height of the animal at the shoulder is three feet. From the middle of the occipital crest, along the curve of the superior surface of the skull, to the tips of the nasal bones is thirteen and a half inches, the same measuremeut in adult animals being twenty-two inches.

The single milk-incisor on each side of each jaw is still in place, as are all the milk-molars. The first true molar has not cut the gum ; but its cap is seen within the bony alveolus. No traces of the
other molars are visible. 
Mr. E. Gerrard has kindly lent me the skull for examination. In its base it exhibits the characteristic peculiarities of the species so clearly enunciated by Prof. Flower ${ }^{1}$, the vomer being free behind and developed into a tongue-shaped process; the mesopterygoid fossa being expanded, and the free ends of the pterygoids everted at the same time that they are broad. No second combing-plate is present on the uncut first upper molar tooth.

The animal is too young to be contrasted advantageously with Prof. Peters's drawing ${ }^{2}$ of Rhinoceros inermis, Lesson. I have, however, taken the opportunity of comparing that figure with the skulls of $R$. sondaicus in the College-of-Surgeons' Museum, and fail to see

Fig. 1.

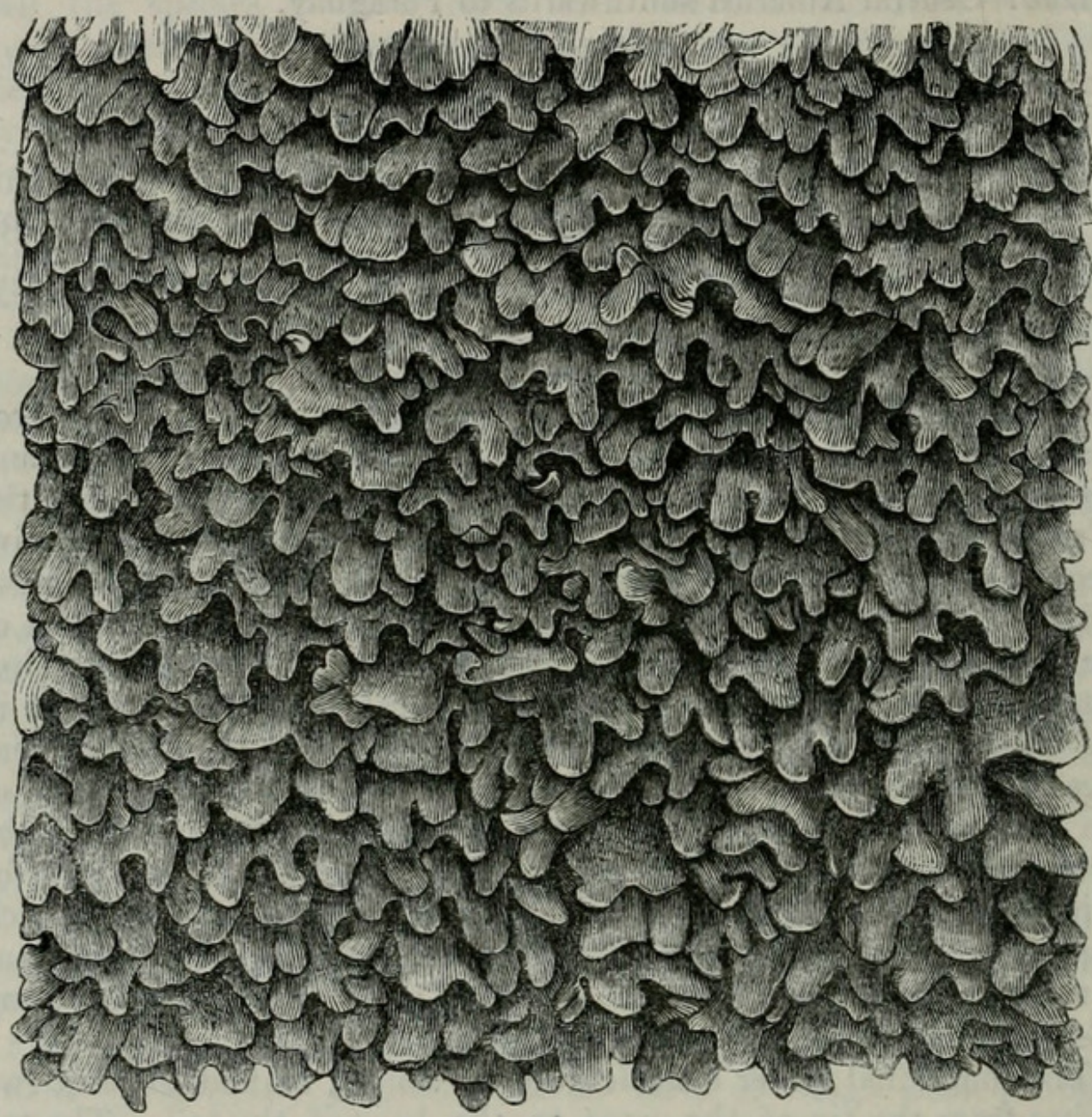

Mucous surface of duodenum of Rhinoceros sondaicus.

that there are sufficient differences to justify specific differentiation. Prof. Flower had previously done the same, and had arrived at a similar conclusion, as he found that even greater differences than those pointed out by Prof. Peters are to be detected in individuals which are all undoubtedly of Indo-Malay origin.

P.Z.S. 1876 , p. 447.

2 Monatsb. der königl. Akad, zu Berlin, 1877, p. 68, pl. ii. 
In skin-folding and surface-texture the Sunderbund and Javan specimens agree exactly; the young Sunderbund animal presenting a most striking uniformity in the size of the epidermic tuberculation, except in the gluteal region, where the boiler-bolt-shaped tubercles are somewhat larger than elsewhere. Along the back the scattered brown hairs, which spring from the yielding linear intertubercular surfaces, are also well developed.

Fig. 2.

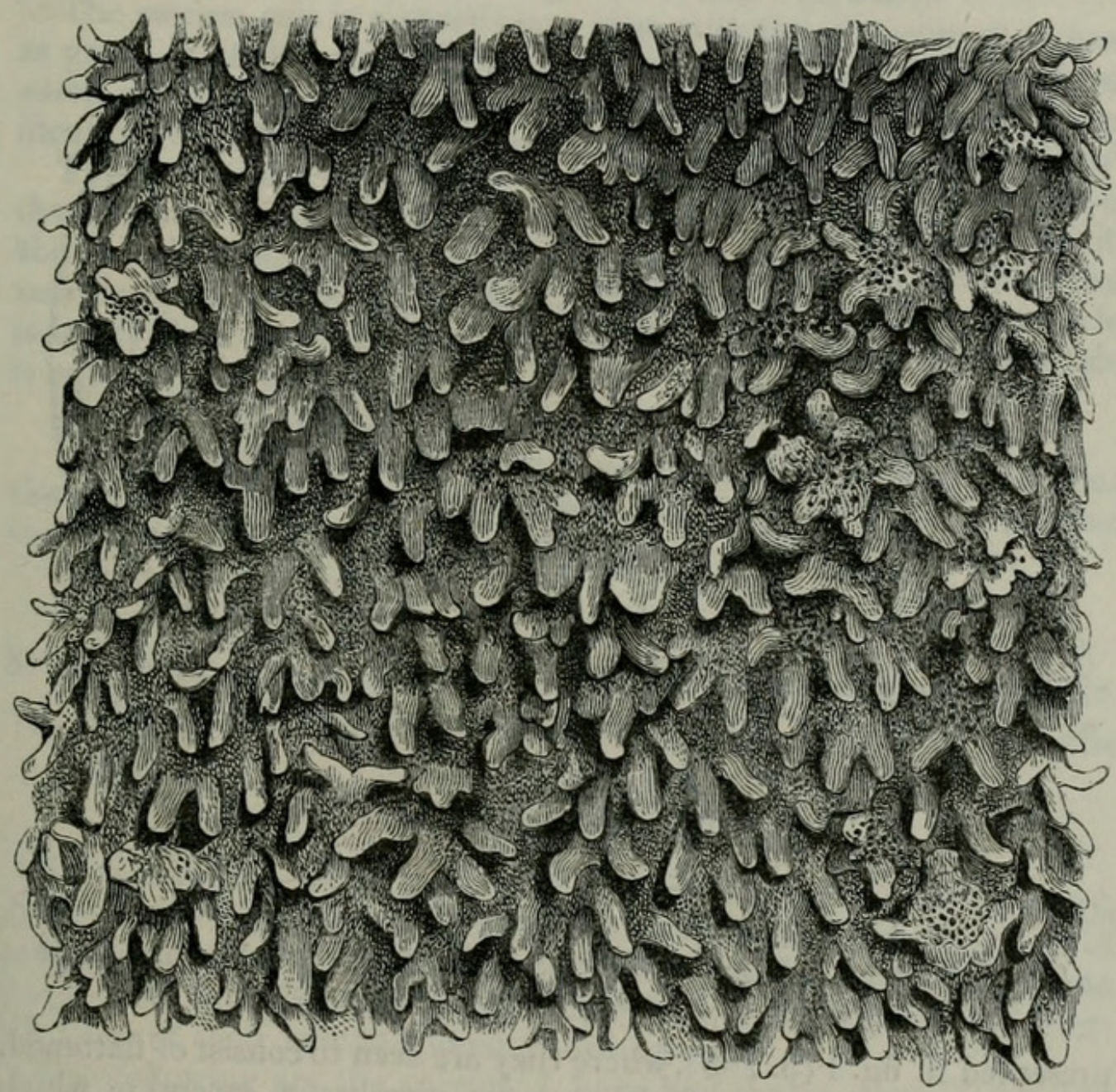

Mucous surface of ileum of Rhinoceros sondaicus.

The following are the lengths of the alimentary viscera :-

Small intestine, 26 feet 2 inches.

Large intestine, 9 feet 10 inches.

Cæcum, 1 foot 3 inches.

The stomach, in shape, is very much like that of $R$. unicornis as figured by Prof. Owen. Its cardiac surface is lined with the smooth white squamous epithelium found in all the Perissodactyla. This occupied about one third of the total gastric area, extending along most of the lesser curvature, the rest being covered with a smooth 
and thick digestive coat. There is no trace of any œsophageal valve like that found in the Horse.

The small intestine is somewhat larger in the duodenal region than elsewhere. Its first three inches are destitute of the flattened papillæ found elsewhere; but here, as all along the small intestines, minute villi are present everywhere. Three inches from the pylorus the papillæ commence, and resemble those similarly situated in Rhinoceros unicornis ${ }^{1}$, except that they are not quite so long. They are re-

Fig. 3 .

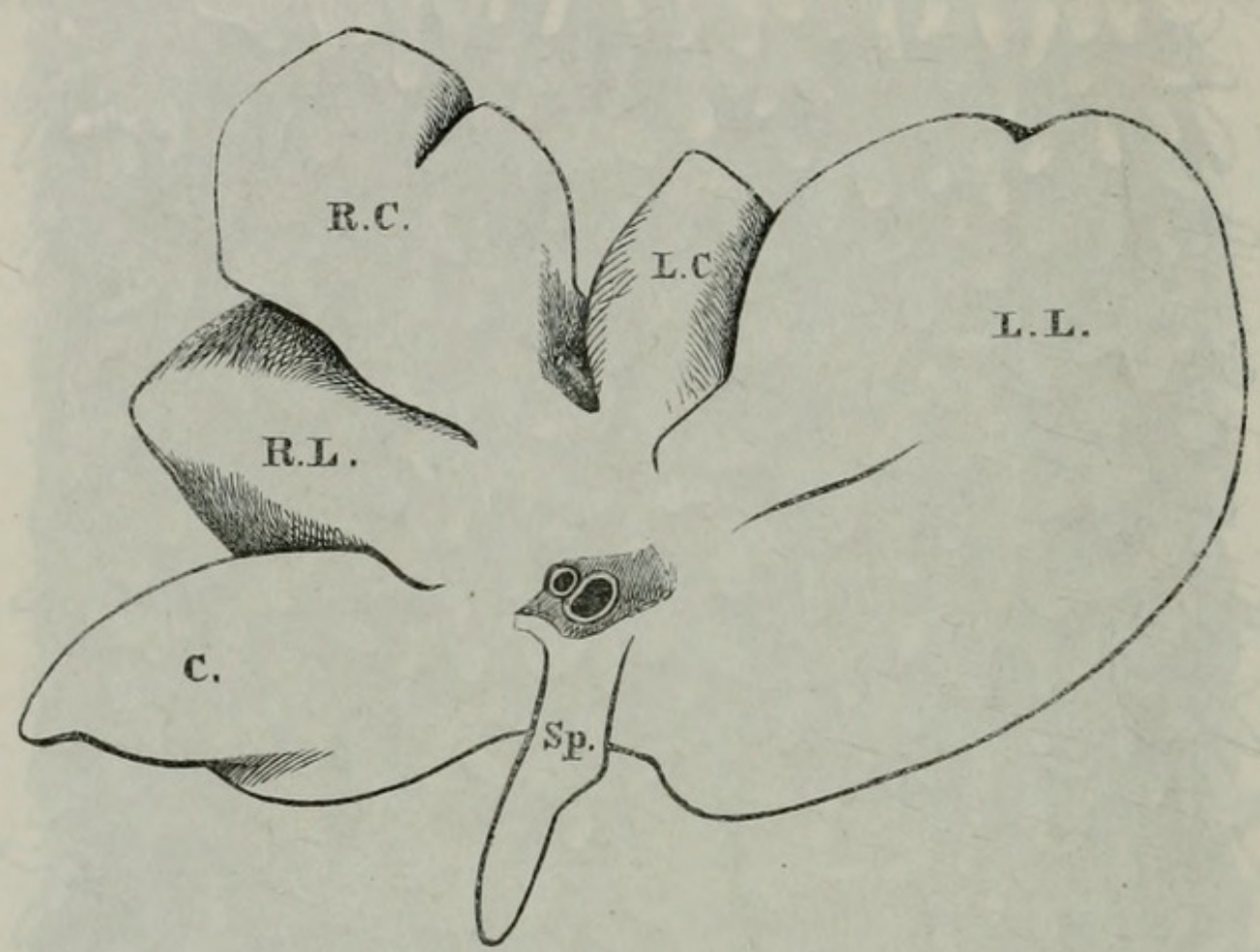

Liver of Rhinoceros sondaicus. Visceral surface.

L.L. Left lateral. L.C. Left central. R.C. Right central. R.L. Right lateral. C. Caudate. Sp. Spigelian lobe.

presented in fig. 1 (p. 708), where they are seen to consist of flattened, round-tipped processes of the mucous membrane, several of which are blended at their bases, in transverse lines. None are more than $\cdot 3$ of an inch in length, and most about $\cdot 6$ inch broad where they first become free. They give the impression of being incomplete valvulæ conniventes which have been cut and deeply jagged at their free edges. The opening of the bile-duct is 7 inches from the pylorus, being a nipple-like tubular projection, nearly an inch long, among the papillæ. From the spot where they commence, all the way to the ileo-cæcal valve, these papillæ are found-those near the last-named situation differing from those in the duodenum in being more scattered and freer from one another, many in the ileum springing independently from the mucous membrane. Nowhere,

1 Vide Prof. Owen's figure, Trans. Zool. Soc. vol. iv. pl, xii. fig. 1. 
however, are they otherwise than flattened, broad, and blunt-tipped, none anywhere being circular and slender like those in the ileum of R. unicornis ${ }^{2}$, the existence of which I have had the opportunity of verifying. They never exceed $\cdot 3$ of an inch in length. Numerous Peyer's patches exist in the ileum, as may be inferred from fig. 2 (p. 709) which is a representation of a portion of the inner surface of the small intestine quite close to the ileo-cæcal valve.

Such being the case, $R$. sondaicus differs from $R$. indicus in that the papillæ of the ileum are short, flat, and broad, instead of long, cylindrical and narrow, "like tags of worsted" (Owen).

The cæcum coli is a short blunt cone, with the diameter of its base as great as its length ( 1 foot 3 inches); and comparing the disposition of the colic flexures and proportionate diameter, I found them identical with those of the Sumatrau species as I have figured them ${ }^{2}$.

The liver wants the gall-bladder, and differs but little from that of the Sumatran species. Fig. 3 (p. 710) is an outline-sketch of its abdominal surface, which, when compared with that of Ceratorhinus sumatrensis (P.Z. S. 1873, p. 102), shows that the right central lobe is larger than the right lateral, instead of smaller. The spigelian lobe is equally long and slender.

The pancreas is of good size and fairly concentrated.

The uterus is bicorn, each cornu measuring 8 inches, at the same time that the corpus uteri is 3 inches long. Each ovary is situated in a pocket of the peritoneum.

\section{Note on an Anatomical Peculiarity in certain Storks. By A. H. GaRrod, M.A., F.R.S., Prosector to the Society.}

[Received October 1, 1877.]

The Ciconiidæ, whilst presenting great uniformity in their myology, differ among themselves in one feature which seems to me to be of sufficient interest to deserve special record, as it may aid those who study their external characters to arrive at a more satisfactory determination of their affinities among themselves.

The following are the species I have had the opportunity of dissecting :-

Ciconia nigra.

- alba.

- boyciana.

- maguari.

Abdimia sphenorhyncha.
Xenorhynchus australis. - senegalensis. Leptoptilus crumeniferus. - argala.

In all these birds, with the exception of Abdimia sphenorhyncha and Xenorhynchus senegalensis, I have found the ambiens muscle, which courses obliquely through the front of the capsule of the knee,

1 Trans. Zool. Soc. vol. iv. pl. xii. fig. 3.

${ }^{2}$ P. Z.S. 1873 , pp. 99, 100. 
present, although never large; whilst in the two last-named birds, both from Africa, it is absent on both sides of the body. Such being the case, it seems to me highly probable that the relationship between Abdimia sphenorhyncha and Xenorhynchus senegalensis is more intimate than that between $X$. senegalensis and $X$. australis; and this view is favoured by their geographical distribution.

The tendency of the ambiens muscle to vanish in certain of the birds so closely allied as the Storks under consideration, in certain Psittaci, as well as in some of the Columbæ, is one which our knowledge of their habits does not enable us to explain. It can have no relation to the habits or bulk of the species; for this muscle is present in the Ostrich as well as in the smallest Cuckoo, whilst it is absent in the Cassowaries and the Passeres. The fact that it is not found in certain Storks makes its total loss in the Ardeidæ less surprising than it would otherwise be.

6. On the Shells of Lake Nyassa, and on a few Marine Species from Mozambique. By Edgar A. Smith.

[Received September 29, 1877.]

(Plates LXXIV. \& LXXV.)

The British Museum has recently acquired a small series of shells collected by Mr. F. A. Simons at Lake Nyassa, and a few obtained by him at the mouth of the Macusi river, near Quilimane, on the east coast of Africa.

Among the former are several very interesting though small species, which, as far as I have been able to ascertain, are undescribed.

As complete lists of species from restricted localities are very useful, I have brought together all those which are known inhabitants of the lake. Fourteen, collected by Dr. Kirk, are all that have as yet been recorded; and now I am enabled to add eleven others to that number.

Of these the Melania polymorpha is very remarkable, as showing the great variation to which some Melanice are subject; and, indeed, I do not feel at all certain that the two forms, $M$. pupiformis and $M$. turritospira are not very abnormal growths of the same shell.

\section{Lake-Shells.}

1. Melania tuberculata, Müller.

Hab. Lake Nyassa (Simons and Dr. Kirk).

Four specimens of this variable species from the lake differ from the normal and usual form in having the whorls less convex. There is a narrow white zone at the top of the whorls next the suture; and beneath a pale-olive epidermis the shell is semitransparent, whitish, and ornamented with series of minute red dots. The longitudinal ribs 


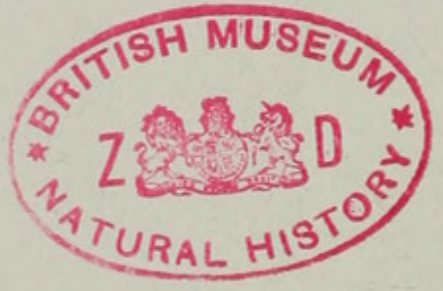



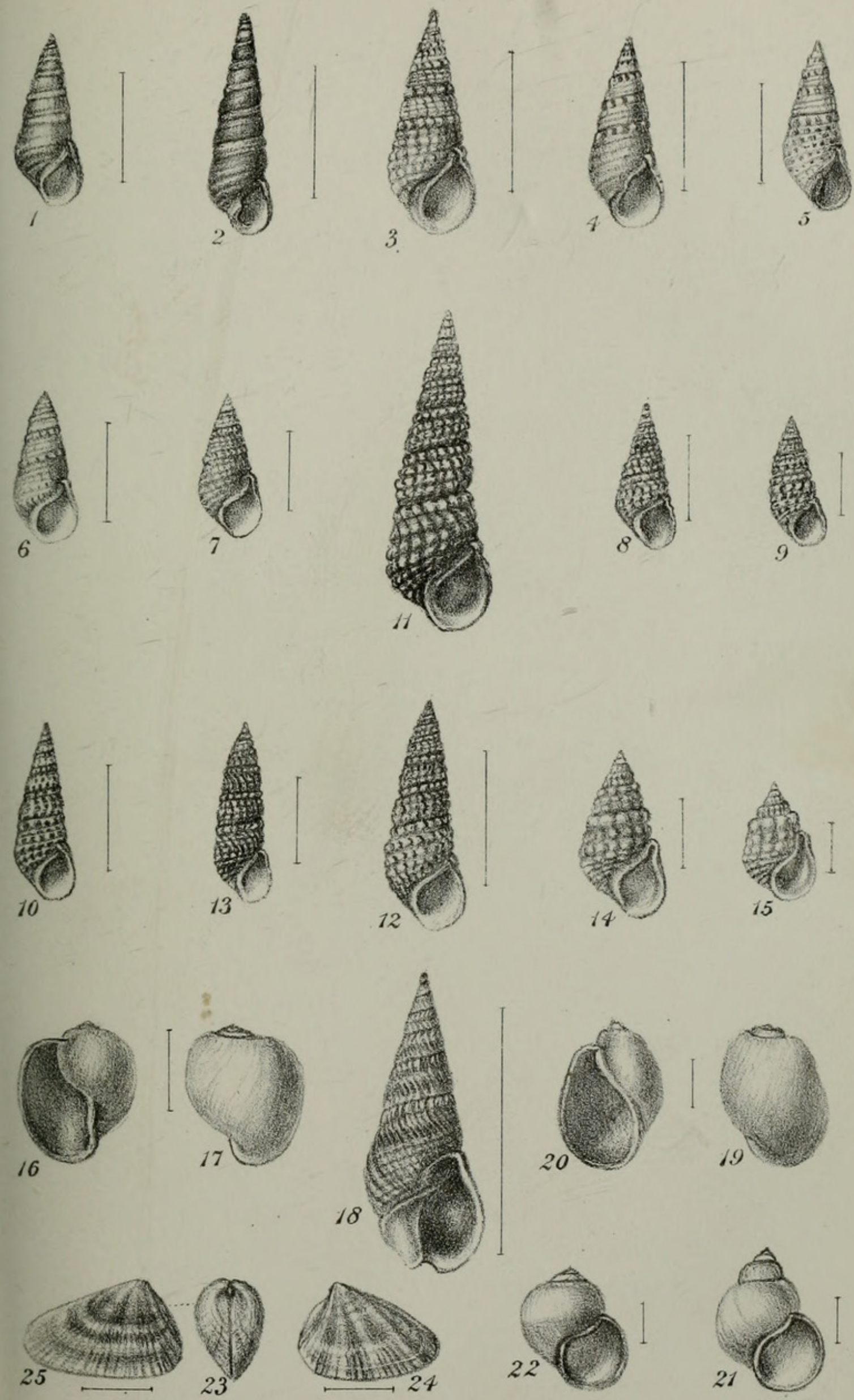

G.Sowerby lith.

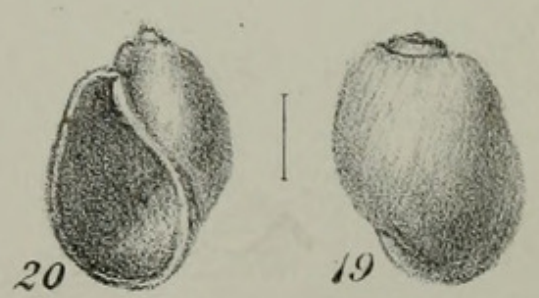
NEW SHELLS FROM LAKE NYASSA \& MOZAMBIQUE. 

are fine, and about eighteen on a whorl, those on the penultimate volution bearing about eight nodules.

\section{Melania turritispira. (Plate LXXV. figs. 14, 15.)}

Shell small, turreted, ovately fusiform, pale olive; whorls seven or eight, flat, with a raised infrasutural belt, furnished with coarse ribs, and sculptured with a few spiral striæ, nearly obsolete on the upper whorls, except the one which marks off the raised band at the suture; on the body-whorl the ribs become obsolete at the middle, where it is angulated, and the transverse striæ are about eight in number; the three or four upper ones crossing the costæ give them a somewhat nodose appearance; aperture small, subovate, acuminate above.

Length 8 millims., diam. $3 \frac{1}{2}$. Aperture 3 long.

This curiously short stunted-looking species is remarkable for its peculiar form, the turreted spire, and the strongly developed nodulous upper extremities of the longitudinal ribs forming an infrasutural belt.

Certain varieties of $M$. polymorpha approach the present species in the style of sculpture; but the very different form of the latter and the absence of spotting easily distinguish it.

The specimens now described may not be full-grown; but it is to be presumed that larger examples would still exhibit the same short stunted form.

\section{Melania púpiformis. (Plate LXXV. fig. 13.)}

Shell cylindrical, subpupiform, covered by a greyish epidermis ; whorls nine, flattish, constricted just beneath a raised belt at the suture, somewhat turreted, separated by a deep suture, furnished with coarse flexuous ribs, which are nodulous at the upper extremities through being crossed or intersected by a spiral furrow a little beneath the suture; below this there are faint indications of one or two other transverse striæ, giving the ribs a subnodose appearance. On the body-volution the ribs are almost obsolete; but around the middle two or three spiral sulci are more distinct than those on the upper portion of it. Aperture small, acutely ovate, occupying less than one third of the whole length of the shell.

Length 11 millims., diam. $3 \frac{1}{2}$. Aperture $3 \frac{1}{2}$ long.

The cylindrical pupoid form of this little species is very remarkable. The last three whorls are of about the same diameter; and above these the spire rapidly diminishes, forming a short cone at the apex. The ribbing is very strong for so small a shell.

Only two examples of this species have come under my observation; but Mr. Simons informs me that he has seen several others, and among them some which were larger than that now described.

\section{Melania simonsi. (Plate LXXV. fig. 3.)}

Shell acutely pyramidal, thinnish, whitish spotted with red; whorls $9-10$, divided by a deep, slightly oblique suture, but little convex, furnished with obliquely arcuate granulous ribs, which num- 
ber about sixteen in the last whorl; the granules are produced by transverse sulci, which cut the ribs at right angles; they are squarish and four or five in number on the ribs of the upper whorls, and the same on the body-whorl, where they terminate about its middle, beneath which the spiral ridges between the sulci are simple, and rather finer than those at the upper part of the volution; aperture acuminately ovate, occupying rather more than one third of the entire length of the shell.

Length 18 millims., diam. $6 \frac{1}{2}$.

This species must not be confounded with $M$. nodicincta, Dohrn, also found at Lake Nyassa. Although in sculpture there is certainly much resemblance, the very different form and proportion of the whorls indicate the specific distinctness of this pretty shell. The spire is produced to quite an acute apex; and its outlines are rectilinear. The nodules on the ribs are large for the size of the species, squarish, and in oblique curves. The red dots are for the most part situated in the interstices between the ribs, at the base of each nodule, thus forming both longitudinal and transverse series.

\section{Melania polymorpha. (Plate LXXV. figs. 4-10.)}

Shell elongate, pyramidal, thin, under a pale-olive epidermis, whitish, spotted with reddish brown ; whorls $8-9$, almost flat, sometimes somewhat convex, margined above at the suture, which is deep and subcanaliculate, either with or without longitudinal plicæ, nodulous through being intersected by a few transverse striæ; the plicæ are usually only on the upper whorls, but in some specimens there are traces of them on the last, or they are well developed; the bodywhorl is generally sculptured with $3-4$ spiral sulci at the periphery, and by other less distinct striæ above and below it ; aperture ovateacuminate above, varying in length, occupying either a little more or less than half the entire shell, pale horn-colour, spotted with reddish brown.

Length 16 millims., diam. $5 \frac{1}{2}$. Another specimen 14 millims. long, and $4 \frac{1}{2}$ wide.

The form of this species is subject to great variation; and the extremes, taken apart from intermediate varieties, have decidedly the aspect of distinct species. The sculpture is also very different in certain specimens, some being almost smooth, with the exception of the spiral sulci on the body-whorl, and a few less distinct striæ on this and the upper volutions. Others are distinctly ribbed, the ribs being cut across by two spiral striæ in the upper whorls, thus producing three granules on each rib, the uppermost situated at the suture on the thickened margin. This incrassation is constant in all specimens; and so is the deep suture, which gives the spire a turreted aspect. Six small examples have the thickened margin very strongly developed, the longitudinal ribs particularly granulous, and present on the body-whorl, terminating at the periphery, where they are limited by a few distinct spiral sulci.

The disposition of the reddish-brown spotting and markings is not constantly the same. Generally a series of dots, short, rounded, 
or elongate, becoming a short line, is situated on the raised infrasutural thickening, and beneath this two transverse series, sometimes coalescing and forming a short line. On the body-whorl there are other series below the middle, which also in some shells unite and form short flames.

\section{Melania nyassana. (Plate LXXV. figs. 1, 2.)}

Shell acutely pyramidal, dark madder-brown, thin, somewhat shining; whorls nine, margined beneath the suture by a distinct raised band, which is marked off by a spiral striation, convex infeferiorly, and somewhat constricted above; the few upper whorls with faint longitudinal ribbing, the rest smooth, with a few distant impressed spiral lines, only faintly visible on most of the whorls, but well defined around the base of the last; aperture rather small, madder-brown, oval, acuminate above, occupying about one third the entire length of the shell; columella arcuate, joined to the outer lip by a thin callosity overspreading the body-whorl.

Length 14 millims., diam. $4 \frac{1}{2}$.

Var. Shell narrower, more cylindrical and elongated, the mouth occupying about one fourth of the entire length. Length 20 millims., diam. $5 \frac{1}{3}$ (fig. 2).

This species is very distinct, on account of its dark madderbrown colour, which is almost uniform, except that the raised band beneath the suture is generally paler brown. The spiral striæ are very indistinct on the upper whorls, especially near the middle ; but just below the periphery, and at the base of the ultimate whorl, they
become well defined.

The variety is represented by a single shell, and in all probability is an abnormal growth; for in all respects, with the exception of its
greater length and more cylindrical form, it is identical.

7. Melania nodicincta, Dohrn. (Plate LXXV. figs. 11, 12.)

Melania nodicincta, Dohrn, P.Z. S. 1865, p. 234.

Hab. Lake Nyassa (Dr. Kirk).

8. Lanistes ovum, Peters.

“Lanistes ovum, Peters," Troschel, Wiegmann's Archiv, Jahrg. xi. Bd. i. (1845) p. 215 ; Philippi, in Kuster's Con. Cat. p. 22, pl. 6. f. 2 , pl. 7 . f. 7 ; Martens, in Pfeiffer's Novitates Conchol. (not seen Hab. Mozambique (Peters), Lake Nyassa (Kirk), teste Dohrn.

9. Lanistes nyassanus, Dohrn. (Plate LXXIV. figs. 8, 9.)

Lanistes nyassanus, Dohrn, P. Z. S. 1865, p. 233.

Two young shells, one about an inch in length, and the other half that size, were the only ones collected by Mr. Simons. Both have the spire completely flattened, and a distinct though rather narrow umbilicus, which, in the adult state, becomes closed by the reflexion
of the columellar callosity. 
10. Lanistes solidus, sp. nov. (Plate LXXIV. figs. 10, 11.)

Shell thick, solid, imperforate when adult, globosely ovate, yellowish olive, with the faintest indication of spiral linear bands, smooth with the exception of roughish lines of growth and most minute (almost obsolete) spiral striæ not visible to the naked eye ; whorls $4 \frac{1}{2}$, with a broad shallow depression or excavation above, then very convex ; last whorl large, ventricose, rapidly enlarging towards the aperture, the latter pyriformly ovate, purplish, or golden and iridescent within, golden towards the lip and on the columella, which is thickened and reflexed over the umbilical fissure; operculum horn-colour, concave exteriorly, with the internal scar roughly corrugated.

Length 42 millims. ; diam. of last whorl, above the aperture, 30 . Length of aperture 30 , diam. 20.

Another specimen is 39 millims. long, 28 wide, and its aperture 30 in length and $18 \frac{1}{2}$ in width.

L. nyassanus of Dohrn is very like the present species in some respects. In solidity, in the absence of an open umbilicus, and in texture it is similar. But the vast difference of form is of itself quite sufficient to separate the two varieties. Neither can $L$. solida be the young state of Dohrn's shell, because the specimens before me have all the appearance of being mature, being solid and very heavy for their size; and on comparison with young examples of that species also obtained by Mr. Simons, the specific distinctness is at once observable.

\section{Lanistes Affinis, sp. nov. (Plate LXXIV. fig. 7.)}

Shell ovate, thin, widely umbilicated, greenish olive, with a narrow yellow line winding around the top of the whorls at the suture, smooth, shining, sculptured with oblique lines of increase and most minute spiral striæ, which are only visible under a lens ; whorls five, convex ; aperture ovately pyriform, purplish, and iridescent within, becoming yellow at the lips and columella, which is very slightly reflexed. $16 \frac{1}{2}$.

Length 38 millims., diam. $27 \frac{1}{2}$. Length of aperture 26, width

This species may be known from $L$. solida by its more prolonged spire, which consists of half a whorl more than in that species, and by its open umbilicus, which gives the last whorl a very different form.

L. ovum, Peters, is another closely allied form, and at first sight might easily be confused with this species. The latter has a shorter and less conical spire, consists of half a whorl less, and its bodywhorl and aperture are longer.

12. Paludina Jefrereys, Frauenfeld. (Plate LXXIV. figs. 1, 2.)

Vivipara jeffreysii, Frfld. P.Z.S. 1865, p. 659.

This species was first found at Lake Nyassa by Dr. Kirk. The specimens collected by Mr. Simons do not quite accord with Frauenfeld's diagnosis. This author has omitted to mention that the en- 
tire surface is covered with faint spiral striæ, which are distinctly visible to the naked eye. The very shallow depression around the middle of the body-whorl in the type specimen I am inclined to regard as an individual pecularity, and not a specific character : for there is no trace of such a furrow in any of the shells just received. These, for the most part, have the spire rather more elongated than the type, and the umbilicus a trifle narrower. 3, 4.)

13. Paludina capillata, Frauenfeld. (Plate LXXIV. figs.

Vivipara capillata, Frfld. P. Z. S. 1865, p. 659.

Hab. Lake Nyassa (Dr. Kirk).

14. Paludina robertsoni, Frauenfeld. (Plate LXXIV. figs. $5,6$.

Vivipara capillata, Frfld. $l$. $c$.

$H a b$. Same as preceding species.

15. Paludina polita, Frauenfeld.

Paludina polita, Frfld. ; Reeve, Conch. Icon. xiv. sp. 73, fig. 73 ;

Dohrn, P. Z.S. 1865, p. 233.

Hab. South Africa (?). Lake Nyassa (Dr. Kirk).

16. Bythinia stanleyi, sp. nov. (Plate LXXV. figs. 21, 22.)

Shell small, ovate, rather solid, subrimate, dirty white or yellowish, obliquely striated by the lines of growth; whorls four, slowly increasing, very convex; suture simple, rather deep; mouth subcircular, occupying about half the whole length of the shell; peristome stout, thickened.

Length 5 millims., diam. $3 \frac{1}{3}$.

Hab. Lake Nyassa.

The solidity, very convex whorls, and subcircular aperture, are the chief distinguishing characteristics of this little shell. The operculum, of course, takes the form of the mouth, and has the lines of increment rather coarse near the margins.

I dedicate this little shell to Mr. Henry M. Stanley, as a mark of admiration of his undaunted perseverance and achievements in African exploration.

17. Physa nyassana, sp. nov. (Plate LXXV. figs. 16, 17.)

Shell solid, pale olive-brown, narrowly perforate, somewhat triangular, roundly angulated above, and with a very short depressed spire; whorls five, convex, separated by a deep channelled suture, and sculptured by fine lines of growth ; last whorl very large, occupying almost the entire length of the shell, since the spire is very shortly conical and only slightly elevated; aperture large, only a trifle shorter than the whorl, subauriform; columella thickened and a little reflexed, subtortuous, and connected with the upper extremity of the outer lip by a thin callous deposit upon the whorl.

Proc. Zool. Soc.-1877, No. XLVII. 
Length 10 millims.; diam., with aperture, $8 \frac{1}{2}$; length of aperture 9 , diam. 4.

Hab. Lake Nyassa.

This species is remarkable on account of its solidity, the short subtriangular form, and the small spire, which rises but very little above the rounded angle or shoulder of the last whorl.

The columella is nearly perpendicular, with a slight sinuosity inferiorly.

18. Physa succinoides, sp. nov. (Plate LXXV. figs. 19, 20.)

Shell small, ovate, moderately solid, imperforate, pale greyish brown; whorls three, convex; suture deep; spire very small, scarcely exserted above the body-whorl; the latter very large, rather strongly striated by the oblique lines of growth; aperture ovately auriform, occupying about $\frac{8}{11}$ of the entire length of the shell; columella oblique, sinuated in the middle.

Length $5 \frac{1}{2}$ millims.; diam., with aperture, 4 .

Hab. Lake Nyassa.

This little species is peculiar in its form, which reminds one of a small sinistral Succinea. The shortness of the spire, and the fewness of the volutions are the most prominent features.

19. Physopsis africana, Krauss.

Physopsis africaua, Krauss, Südafrik. Moll. p. 85, pl. v. f. 14 ; Küster, Conch. Cab. p. 72, pl. 12. f. 29, 30 ; Adams, Gen. Rec. Moll. iii. pl. 83. f. 10.

Physa africana, Krauss, Sowerby, Con. Icon. xix. pl. 1. f. $2 a-b$.

Hab. Port Natal (Krauss). Lake Nyassa (Kirk), teste Dohrn, P. Z. S. 1865 , p. 233.

20. Limnea natalensis, Krauss.

Limncea natalensis, Krauss, Südafrik. Moll. p. 85, pl. v. f. 15 ; Kuster's Con. Cat., No. 42, pl. 6, f. 1, 2, 3; Sowerby, Conch. Icon. xviii. pl. 7 , f. $46 a-b$.

Hab. Natal (Krauss). Lake Nyassa (Kirk). Dohrn, l. c.

21. Cyrena astartina, Martens.

Cyrena astartina, Martens, Malak. Blätt. vi. (1859) p. 219, pl. 3 . f. 6, 7 ; Prime, Cat. Corbiculidæ, American Journ. Conchol. v. no. 7 (Corbicula) ; Dohrn, P. Z. S. 1865, p. 234.

Hab. Tette, Zambezi River (Martens); Lake Nyassa (Dohrn and Prime).

22. Cyrena (Corbicula) radiata, Parreyss.

Cyrena radiata, Parr. Philippi, Abbild. ii. p. 4, pl. i. f. 8.

C. africana, Krauss, part, Südafrik. Moll. p. 8.

Three specimens of this Nilotic species were obtained by $\mathrm{Mr}$. Simons in the Lake. One of them is rather more inequilateral than normal examples, having the posterior end somewhat the longer. The concentric sulcation, too, in all three shells, is a little finer, and the violet rays somewhat obscure. 
23. UnIo NYASSAËnsis, Lea.

Unio nyassaënsis, Lea, Proc. Acad. Nat. Sci. Philad. 1864, p. 108 ; Journ. Acad. Nat. Sci. Philad. (1866), vol. vi. p. 33, pl. 12. f. 32.

U. nyassa, Sowerby, Conch. Icon. sp. 224, f. 224, $a, b$.

U. nyassensis, Lea, Sowerb. op. cit. Errata and Index.

Var. $=U$. kirkii, Lea, l. c. p. 108 ; Journal, p. 32, pl. 12. f. 30.

Var. $=U$. aferula, Lea, l. c. p. 109 ; Journal, p. 34, pl. 13. f. 34 .

Hab. Lake Nyassa (Dr. Kirk).

This species, like many others of this genus, is subject to considerable variation in form and sculpture. The three forms described by Lea are evidently nothing more than mere varieties of one and the same shell.

\section{Spatha alata, Lea.}

Spatha alata, Lea, Proc. Acad. Nat. Sci. Philad. 1864, p. 109 ; Journ. Acad. Nat. Sci. (1866) vol. vi. p. 35, pl. 12. f. 31.

$H a b$. Lake Nyassa (Dr. Kirk).

25. Spatha nyassaënsis, Lea.

Spatha nyassaënsis, Lea, l.c.p. 109 ; Journal Acad. Nat. Sci. Philad. p. 36, pl. 13. f. 33 .

$H a b$. Same as the preceding.

\section{Marine Species.}

1. Bullia mozambicensis, sp. nov. (Plate LXXV. fig. 18.)

Shell elongate, acuminately spired, more or less livid in colour ; whorls nine, the two apical ones smooth and shining, the rest but slightly convex, separated by an oblique suture, sculptured with oblique, somewhat flexuous, fine and close-set plicæ, which extend from suture to suture in the upper whorls, and gradually become obsolete about the middle of the last volution; these riblets or plications, which are about equal in thickness to the spaces between them, give the upper margins of the whorls a finely crenulated appearance, and are subgranulous, through being intersected by spiral striæ, which gradually become wider apart as the shell increases; they are about nine in number on the penultimate whorl; the last is encircled by about 13 ; and the keel which winds around its base is of a brown colour, and the portion of the whorl below it whitish; mouth ovate-acuminate above, occupying a little more than $\frac{3}{8}$ of the entire length of the shell, olive-brown or purplish-brown margined with white within the labrum and at the base; labrum thickened, acute at the edge, and inconspicuously sinuated above; columella arcuate in the middle, thinly coated with a white enamel, which, extending above the lip and winding along the suture, gradually vanishes as it proceeds up the spire.

Length 32 millims.; diam. of last whorl 11 ; length of mouth $12 \frac{1}{2}$, width nearly 6 . Operculum unguiculate, concentrically and transversely striated.

Hab. Mouth of the Macusi River, Quilimane, E. Africa. 
This species is remarkable for the subgranose plications on the whorls, and the brown carina of the body-whorl. It is difficult to describe in a few words the colour of this interesting form. The general appearance is livid, inclining to yellow or very pale olive ; one shell is livid, with the upper margin of the whorls reddish. The callous band is quite conspicuous only about halfway around the body-whorl, and then gradually fades away, and is only noticeable further up the spire by slightly obliterating the lower extremities of the longitudinal ribs.

Two not quite adult specimens were collected by Dr. Kirk at the delta of the Zambesi River, and were placed in the British Museum by Earl Russell.

2. Natica antoni, Philippi.

Natica antoni, Philippi, Zeitschrift für Malakozool. 1851, p. 48 ; Küster's Conch. Cab. p. 144, pl. 19. f. 18.

$H a b$. Mouth of the Macusi River, near Quilimane, E. Africa.

Nothing can be added to Philippi's excellent description of this interesting species; but I may mention that a young specimen has a distinct pale zone around the middle of the last whorl, between the two series of brown spots, which are more or less obsolete in the adult shell, and that its umbilicus is quite filled up with the callosity, even in the immature condition. The operculum is shelly, white exteriorly, except near the nucleus, where there is a small pale brownish callous deposit. The surface is smooth and shining, sculptured with the lines of growth, and a single distinct striation parallel with the outer edge, thus marking off a separate margin. From the nucleus a short ridge or rib extends itself towards the centre. The inner or under surface is clothed with a thin, pale yellow epidermis.

\section{Tellina opalina, Chemnitz.}

Tellina opalina, Chemnitz, Küster's Conch. Cab. p.172, pl.35. f. 8. Tellinides rosea, Sowerby, Gen. Rec. and Foss. Shells, f. 1.

Tellina planissima, Anton; Philippi, Abbild. i. pl. 2. f. 2 ; Thesaurus Conch. f. 197; Conchol. Icon. pl. 13. f. $58 a, b$.

(Non T. opalina, Sowerby, Conch. Icon. sp. 258, f. 258 a, b.)

$\mathrm{Hab}$. Mouth of the Macusi River, near Quilimane, E. Africa.

Only a single specimen, which apparently belongs to this species, was collected. It differs from the normal form in being rather more equilateral. It is pale rose-colour, almost white at the umbones, and at the ligamental area; and the internal raised radiating ribs are well defined. The name opalina, proposed by Sowerby for a species in the collection of $\mathrm{Mr}$. Hanley, must be changed should it prove to be a well-defined species.

4. Tivela dolabella, Sowerby.

Cytherca dolabella, Sowerby, Thesaurus Conch. iii. p. 619, pl. 127. f. 15 ; Reeve, Conch. Icon. xiv. sp. 2.

Hab. Mouth of the Macusi River, Quilimane, East A frica.

This species was originally described from a specimen in Cum- 
ing's collection, said to have been from the Red Sea. The shell from Mozambique agrees perfectly with the type, except that the posterior end is rather less produced. I should add that the figure in the 'Conch. Icon.' considerably exaggerates the beaked appearance of this portion of the type shell. The lunule is elongate, narrow, and defined by a simple striation on each valve.

\section{Donax madagascariensis, Wood.}

Donax madagascariensis, Wood, Index Testaceolog. Suppl. p. 5, pl. 2. f. 3 ; Sowerby, Thesaurus, iii. pl. 280 . f. 16 ; Reeve, Conch. Icon. viii. sp. 50.

D. Keyii, A. Adams, P. Z. S. 1854 , p. 87.

Hab. Macusi River, near Quilimane, East Africa.

The radiating striæ and the ridges between them are much more strongly developed on the posterior cordiform area than on the anterior surface. On the other hand the oblique ridges on the latter portion of the shell are much stronger than on the former, where they become thin lamellæ. The lines of growth are curiously present on the oblique costæ, near the anterior ventral margin of the valves, but not visible in the interstices between them.

\section{Donax amulus. (Plate LXXV. figs. 23-25.)}

Shell small, triangular, somewhat elongate, very inequilateral, produced anteriorly, compressed and narrowly rounded, posterior area cordiform, not very acute at the margins, slightly sinuated at the middle; radiately striate, except for a narrow space at the anterior dorsal slope; the striæ are very fine, equidistant, those on the posterior area deeper and wider, with distinct intermediate lirulæ, which are decussated by still more prominent obliquely ascending ones, which do not pass beyond the rounded carina; umbones acute, but little incurved ; interior dorsal slope rectilinearly sloping, posterior very suddenly inclined; ventral margin straightish; lunule linear ; ligament small, prominent.

Colour yellow, purplish, or cinereous, generally varied with darker concentric bands and purplish radiating rays, most distinct within the valves, which are more or less purple, generally white at the crenulated margins.

Length $9 \frac{1}{2}$ millims., height 6 , thickness 4 .

$H a b$. Mouth of the Macusi River, near Quilimane.

This pretty species reminds one very much of the West-African D. elongatus. However, it is a trifle shorter, has not the rugose line on the posterior area, nor the flatness in the centre of that part.

\section{EXPLANATION OF PLATES LXXIV. \& LXXV.}

\section{Plate LXXIV.}

Fig. 1, 2. Paludina jeffreysi, p. 716 .

3, 4. - capillata, p. 717 .

5, 6. - robertsoni, p. 717 .
Fig. 7. Lanistes affinis, p. 716.

8, 9. - nyassanus, p. 715 .

10, 11. - solidus, p. 716 . 


\section{Plate LXXV.}

Figs. 1, 2. Melania nyassana, p. 715 .

3. - simonsi, p. 713.

4-10. - polymorpha, p. 714 .

11, 12. - nodicincta, p. 715 .

13. — pupiformis, p. 713.

14, 15. — turritispira, p. 713 .
Fig. 16, 17. Physa nyassana, p. 717.

18. Bullia mozambicensis, p. 719.

19, 20. Physa succinoides, p. 718. 21, 22. Bythinia stanleyi, p. 717. 23-25. Donax cemulus, p. 721.

7. On a new Species of Petrel from the Feejee Islands. By Dr. Отто Finsch, C.M.Z.S., Director of the Bremen Museum.

[Received July 2, 1877.]

\section{Procellaria albigularis, sp. nov.}

Head, quills, and tail sooty black; back, shoulders, and wingcoverts lighter, more of a sooty brown; the largest row of the upper wing-coverts at the tips washed with light brown, forming an illdefined narrow cross band; the black of the head covers the sides and the chin-margin; below the latter is a semilunar white space, extending lateraliy to below the ear-region and bounded below by a very broad sooty black cross band, which commences at the junction of the wing; below this the remaining undersurface is white, as is the hind portion of the rump and upper tail-coverts; the longest under tail-coverts are sooty blaek, as are the under wing-coverts along the carpal and hind margins; the middle row of under wingcoverts white, as the axillaries; the greater under wing-coverts ashy, with white tips; the feathers of the sides of the vent and flanks with black shafts, forming very narrow dark striæ; tail-feathers on base of inner web white, passing into brown. Bill and feet black. Tail forked, its feathers very broad and truncated at the apex; the wings reach a little beyond the tail.

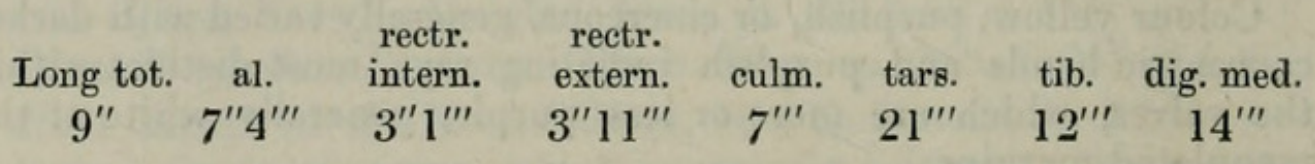

Hab. Feejee Islands, South Pacific.

The above description is taken from a female specimen from Kandavu, Feejee Islands, taken on the nest on the 10th of September, 1876 , and sent over by Mr. Theodor Kleinschmidt to the Museum Godeffroy.

The large size, the deeply forked tail, and the singular coloration distinguish this species at once from any other member of this group. 
8. Reports on the Collection of Birds made during the Voyage of H.M.S. 'Challenger.' No. IV. On the Birds of Tongatabu, the Fiji Islands, Api (New Hebrides), and Tahiti. By Dr. O. Finsch, C.M.Z.S.

[Received October 3, 1877.]

\section{A. Birds of Tongatabu, Friendly Group.}

These are 30 in number. They were collected on July 20, 21, and 22,1874 . Only nine species are represented in the series.

\section{Collocalia spodiopygia, Peale.}

Collocalia spodiopygia, F. \& H. Ornith. Central-Polyn. p. 48 ; Layard, P. Z. S. 1876, p. 501 (Tonga); Finsch, Journ. Mus. Godeffr. Heft xii. 1876 , p. 26. Tonga).

Collocalia, sp. ? F. \& H. Journ. f. Orn. 1870, p. 125 (nest,

No. 11. Tongatabu.

"These little Swallows were seen flying about in numbers on every part of the island at which we were. Shot July $20 . "-J . M$.

Judging from the difference in the structure of the nests obtained by Dr. Gräffe from Tongatabu $(l . s . c$.) and those from the Fijis (Orn. Central-Polyn. p. 276, t. xiv.), I expected to find a different species of Collocalia inhabiting the Friendly group; but on examining the specimens before me, I find them exactly like those from the Fijis and Navigators'. The structure of the nests seems to vary individually. (Cf. Finsch, Journ. f. Ornith. 1872, p. 35, Upolu.)

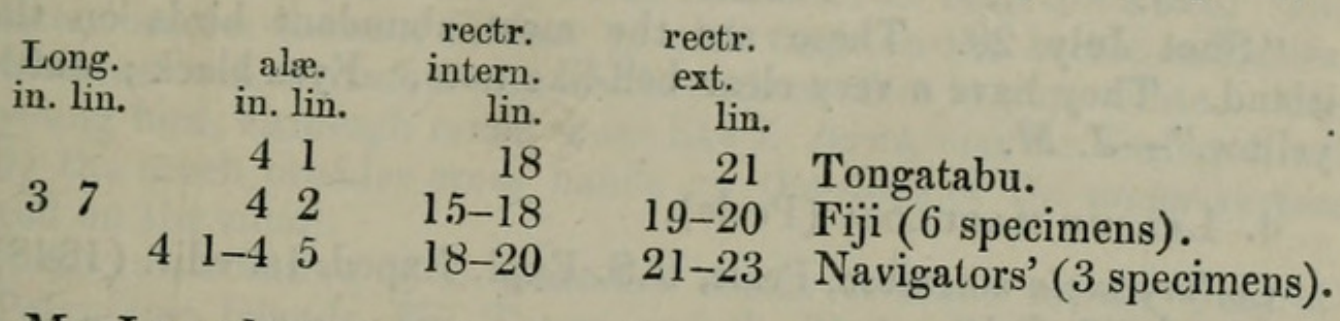

Mr. Layard enumerates also C. vanicorensis among the birds of Tonga, although it was not detected by him. On this latter species compare Finsch, Journ. Mus. Godeff. Heft xii. 1876, p. 23. Its occurrence in the Fijis, which has been alleged by us (Orn. CentralPolyn. p. 47) upon the faith of a specimen sent us by Dr. Gräffe, the only one we saw said to be from thence, is very doubtful.

\section{Halcyon sacra (Gm.).}

Halcyon sacra, F. \& H. Ornith. Central-Polyn. p. 32 ; P. Z. S. 1869, p. 545 (Tonga); Journ. f. Orn. 1870 , p. 1241 (Tonga);
Layard, P. Z. S. 1876, p. 501 .

No. 2. Tongatabu. Male.

3. " Male.

4. " " Female.

5.,$\quad$ Female. 
"Shot July 20; eyes black. These birds were in considerable numbers near the houses of the natives." $-J . M$.

No. 23. Tongatabu. Female.

24. „, Male.

27.,$\quad$ Female.

" Shot July 21.",

Male.

No. 27 (female) has a pure white superciliary stripe; in the other specimens this is washed more or less with cinnamon-rusty, very strongly and broadly in No. 4 (female). Nos. 2, 3, and 4 sbow narrow rusty margins to the upper wing-coverts, which seem not peculiar to the young birds. That both sexes are precisely alike, I can state from dissection of specimens in alcohol. Generally Tonga specimens show a more greenish tinge on the back; but in some specimens (as 5, male, 23, female, and 24, male) the blue is as dark and pronounced as in Fiji specimens, and in some of the latter (as 95 , male and 61 , male) as greenish as in Tonga specimens. The under wing-coverts and sides in the Tonga bird are mostly pure white; but Nos. 3 and 4 show a rusty tinge.

3. Ptilotis carunculata (Gm.).

Ptilotis carunculata, F. \& H. Ornith. Central-Polyn. p. 58; P.Z.S. 1869, p. 545 (Tonga); Journ. f. Orn. 1870, p. 125 (Tonga); Gräffe, ib. p. 404 (habits); Layard, P.Z.S. 1876, p. 501 (Tonga).

No. 12. Tongatabu. Male.

13. " Male.

14.,$\quad$ Female.

15.,$\quad$ Female.

"Shot July 20. These are the most abundant birds on the island. They have a very clear bell-like note. Eyes black; wattle yellow." $-J . M$.

\section{Lalage maculosa (Peale).}

Colluricincla maculosa, Peale, U.S. Expl. Exped. 1st edit. (1848), p. 81, pl. 23. f. 10 .

Lalage terat, Cass. (nec Bodd.), ibid. 2nd edit. (1858), p. 143 ; F. \& H. Ornith. Central-Polyn. p. 80 ; P. Z. S. 1869, p. 546 (Tonga); Journ. f. Orn. 1870, p. 149 (Tonga); Finsch, ibid. 1872, p. 41 (Samoa); Layard, P. Z. S. 1875, p. 433 (Fiji), 1876, p. 494 (Navigators') and p. 502 (Tonga).

Campephaga maculosa, Gray, Hand-l. i. p. 339. no. 5124.

No. 16. Tongatabu. Male.

17. ", Male.

"Eyes white. Common on the island; shot July 20."

No. 29. Tongatabu. Female. "Shot July 21."

32. „, Male. 


$$
\begin{aligned}
& \text { Long. } \\
& \text { alæ. caudr. latit. a front. rostr. tars. }
\end{aligned}
$$

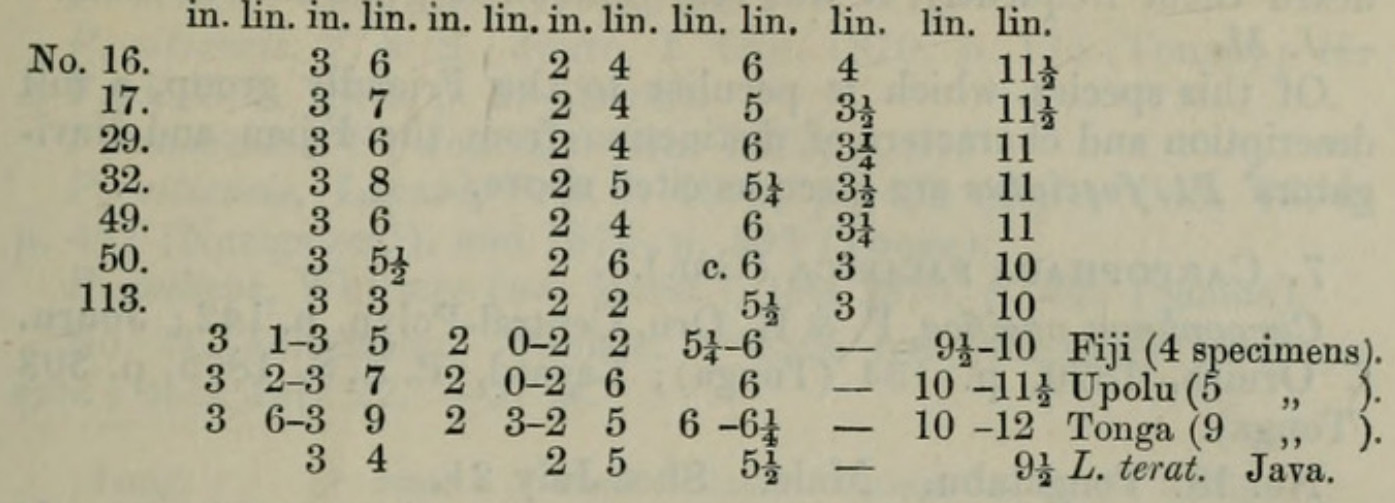

Among the specimens before me Nos. 17, 32, and 49 (Fiji) are adult and fully coloured, which are very rare in collections, and give me a good opportunity of making a close comparison of them with Javan specimens of the true Lalage terat (Bodd.), with which the Central-Polynesian bird has hitherto been confounded. I have myself stated (J. f. Orn. 1872, p. 130) their undoubted identity; but having then seen only young and a few old specimens in bad condition, I was misled. The series before me seems to confirm the views of Mr. G. R. Gray, who keeps the Polynesian bird separate.

The latter may be distinguished from $L$. terat by the grey or brownish-grey rump and upper tail-coverts being always barred by irregular but distinct cross lines, the rump being of a uniform grey with faint darker traces in $\boldsymbol{L}$. terat-by the black shaft-stripe on the white middle row of the upper wing-coverts, which is wanting in $L$. terat-and by the narrow brownish external margin of the primaries and first secondaries, which in the old $L$. terat are white. The latter besides shows a distinct greyish tinge on the breast and sides, whereas in $\boldsymbol{L}$. maculosa the whole undersurface is pure white. The young bird, although much more like $L$. terat, may be distinguished by the much broader cross bands on the sides of the under-surface and on the rump.

The distribution of L. maculosa seems confined to the CentralPolynesian Islands, Fiji, Tonga, and the Navigators'.

5. Aplonis tabuensis ( $\mathrm{Gm}$.).

A. marginata, Gould, P. Z. S. 1836, p. 73.

No. 8. Tongatabu. Male.

9. $\quad " \quad$ Female.

"Shot July 20 and 21. Eyes dark red."-J. M.

6. Ptilinopus porphyraceus (Forst.).

Ptilinopus porphyraceus, F. \& H. Orn. Central-Polyn. p. 119 ; P. Z. S. 1869, p. 547 (Tonga); Journ. f. Orn. 1870, p. 131 ('Tonga); Layard, P. Z. S. 1876, p. 502 (Tonga).

No. 6. Tongatabu. Male. "Eyes yellow."

7. " Male. 
"Shot July 21 and 22 . These birds were very shy; though we heard them frequently, it was very difficult to get a shot at them." $-J . M$.

Of this species, which is peculiar to the Friendly group, a full description and characters of distinction from the Fijian and Navigators' $P t$. fasciatus are given as cited above.

7. Carpophaga pacifica $(\mathrm{Gm}$.).

Carpophaga pacifica, F. \& H. Orn. Central-Polyn. p. 142 ; Journ. f. Ornith. 1870, p. 134 (Tonga); Layard, P. Z.S. 1875, p. 503 (Tonga).

No. 18. Tongatabu. Male. Shot July 21.

"This large pigeon 'coos' very like our pigeon at home. It appears to be common but shy. Eyes red."-J. $M$.

No. 26. Tongatabu. Male. "Eyes red."

31. „, Female.

79. Samoa. Female.

"Eyes and legs red. Presented alive by the Rev. George Brown."

The sexes are alike in plumage; but the female is without the knob on the base of the bill, and exactly agrees with specimens from the Navigators' and the Fijis; the vinaceous tinge in the male birds seems to be more strongly developed during time of incubation.

In our 'Ornithology of Central Polynesia,' Dr. Hartlaub and I erroneously united C.oceanica, Less., with this species; but since then we have shown (P. Z. S. 1872, p. 101, and Journ. Mus. Godeffr. Heft viii. 1875 , p. 26) that the latter is a distinct species, occurring in the islands of the Western Pacific. C. pacifica is confined to the Central-Polynesian Islands.

\section{Ardea sacra, Gm.}

Ardea sacra, F. \& H. Ornith. Central-Polyn. p. 201, Journ. f. Orn. 1870, p. 136 (Tonga); Layard, P. Z. S. 1875, p. 503 (Tonga).

No. 19. Tongatabu. Female. "Eyes yellow."

20. $" \quad$ Female, young.

"Common on the reefs at low water; also met with in the woods through the island. Shot July 21."- $J$. $M$.

No. 22. Tongatabu. Male. Shot July 22.

No. 19 is white, assuming the slate-coloured dress from below and on the back; slate-blue appanage in full development.

No. 20. Slate-blue, with white chin-stripe; the scapular appanage in beginning of development.

No. 22. White, sprinkled on the neck, back, and below with single slate-blue feathers; no development of scapular appanage visible.

On several occasions I have shown that the white dress in this Heron is not dependent upon age or sex, and that at present we are not able to explain the causes of these interesting differences in coloration satisfactorily.

9. Porphyrio samoënsis, Peale.

$P$. samoënsis et $P$. vitiensis, Peale. 
P. vitiensis, F. \& H. Ornith. Central-Polyn. p. 172, t. xii. f. 3.

$P$. indicus, Cass. (nec. Hors., nec F. \& H.).

P. vitiensis, F. \& H., Journ. f. Orn. 1870, p. 135 (Tonga); H. \& F., P.Z.S. 1871, p. 27 (Savai).

P. samoënsis, F., Journ. f. Orn. 1872, p. 55.

P. vitiensis, Layard, P. Z.S. 1875, p. 439 (Fiji); ibid. 1876, p. 497 (Navigators'), and 1876, p. 503 ('Tonga).

P. indicus, Whitmee (nec Horsf.), Ibis 1875, p. 446 (Samoa).

No. 21. Tongatabu. Female. "Eyes red; the only specimen seen ; shot July 22."-J. M.

$\begin{array}{cccccccc}\begin{array}{c}\text { Long. } \\ \text { alæ. }\end{array} & \text { caud. } & \begin{array}{c}\text { rostr. a } \\ \text { rict. }\end{array} & \begin{array}{c}\text { rostr. } \\ \text { scut. incl. }\end{array} & \begin{array}{c}\text { latit. } \\ \text { scut. }\end{array} & \begin{array}{c}\text { long. } \\ \text { tars. }\end{array} & \text { tib. } & \begin{array}{c}\text { dig. } \\ \text { med. }\end{array} \\ \begin{array}{cccc}\text { in. lin. } \\ \text { in. }\end{array} & \begin{array}{c}\text { lin. } \\ \text { in. lin. }\end{array} & \begin{array}{l}\text { lin. } \\ \text { in. lin. }\end{array} & \text { lin. } & \text { in.lin. } \\ & 3 & 16 \frac{1}{2} & 23 & 9 & 210 & 15 & 29\end{array}$

I have already explained (P.Z.S. 1871, p. 27) that P. indicus, Horsf., does not occur in Polynesia, as has been stated by Mr. Cassin, but that the Central-Polynesian Islands (Fiji, Navigators' and Friendly group) possess only one species; P. samoënsis, Peale. The description in the 'Ornithology of Central Polynesia' (p. 170) taken from a Javan specimen of the true $P$. indicus, Horsf., must therefore be cancelled altogether.

Specimens from the Fijis and Tonga group look apparently somewhat larger than those from the Navigators'; but on comparing the series of measurements given, it will be easy to see that in respect to size no specific distinction can be made out. In coloration there is also no difference.

\section{B. Birds of the Fiji Islands.}

These birds were shot on the island of Matuka on July 24, 1874, on the island of Kandavu on July 25 and from August 3 to 6, 1874, and on the island of Levuka from July 28 to August 1, 1874. They are 82 in number and represent 25 species.

\section{Astur rufitorques, Peale.}

Nisus cruentus, Schleg. (nec Gould), Mus. P.-B. Astures, p. 40. Astur cruentus, F. \& H. (nec Gould), Ornith. Central-Polyn. pp. 3 and 273 ; Layard, P. Z. S. 1875 , p. 424.

A. rufitorques, Sharpe, Cat. Brit. Mus. i. p. 121.

Nisus rufitorques, Schleg. Mus. P.-B. Accip., Revue, p. 80 (1873).

No. 34. Matuka. Female. "Eyes brown; several of these were seen, only two shot."'

No. 35. Matuka. Female.

36. " Male. "Eyes yellow."

62. Kandavu. Female. "Eyes yellow ; shot July 27."

80. " Female. "Eyes yellow, cere yellow, legs yellow ; the stomach contained a portion of a lizard. Shot Aug. 5.", 


\begin{tabular}{|c|c|c|c|c|c|c|}
\hline \multirow{11}{*}{$\begin{array}{r}\text { No. } 34 . \\
35 . \\
36 . \\
62 . \\
80 . \\
\end{array}$} & $\begin{array}{l}\text { Long. } \\
\text { alæ. } \\
\text { in. lin. }\end{array}$ & $\begin{array}{l}\text { caud. } \\
\text { in. liñ. }\end{array}$ & $\begin{array}{c}\text { rostr. } \\
\text { a cer. } \\
\text { lin. }\end{array}$ & $\begin{array}{l}\text { tars. } \\
\text { in. lin. }\end{array}$ & $\begin{array}{l}\text { dig. } \\
\text { med. } \\
\text { lin. }\end{array}$ & \\
\hline & 89 & 60 & 8 & & 17 & \\
\hline & 8 & 2 & 8 & 23 & 17 & \\
\hline & 3 & 2 & 7 & 111 & 13 & \\
\hline & 810 & 4 & $8 \frac{1}{2}$ & 21 & 16 & \\
\hline & 89 & 510 & 9 & $\begin{array}{ll}2 & 1\end{array}$ & 16 & \\
\hline & 8 & 62 & & $\begin{array}{ll}2 & 1\end{array}$ & 16 & Ovalau. \\
\hline & 7 & 5 & 7 & 20 & $13 \frac{1}{2}$ & Viti Levu. \\
\hline & 8 & 6 & 8 & 21 & 15 & Ternate. \\
\hline & 10 & 8 & & & & \\
\hline & 8 & 9 & $8 \frac{1}{2}$ & 23 & 16 & Halmahera. \\
\hline
\end{tabular}

In our 'Ornithology of Central Polynesia' we followed Professor Schlegel in uniting the Hawk of the Fijis with Astur cruentus of Australia ; but, as on some other occasions, we depended too much on Prof. Schlegel's authority, and Prof. Schlegel has since declared himself to have been in error. Not having access to specimens, I cannot myself judge of the correctness of Prof. Schlegel's new view; but the fine series now before me inclines me to believe that A. rufitorques is most probably peculiar to the Fiji group, and not the same species as is distributed widely in the Malay archipelago and usually known as $A$. griseigularis and $A$. henicogrammus, Gray ( = A. aquatorialis, Wall.).

In coloration the Fiji specimens are pretty constant, all showing above a beautiful ashy-blue, beneath a fine vinaceous rufous, which latter forms also a broad neck-collar. This is less developed in No. 35, and looks rather imperfect. The under-surface in No. 62 shows a nearly obsolete undulation of narrow darker lines on the ventral region; the under wing-coverts in all the specimens before me are not "uniform white" as noted in his specific diagnosis by Mr. Sharpe (l. $c$. p. 95$)$; but the white is washed with delicate pale vinaceous, which shows in Nos. 34 and 80 faint darker undulations. An old specimen of A. griseigularis is generally conspicuously darker, slaty-brownish on the back, wings, and tail, the underparts also dark vinaceous-rufous with perceptible narrow light cross bands (agreeing exactly with figs. 3, 4, taf. 14, in Schleg. 'Vog. van Nederl. Indië'). A young bird of $A$. griseigularis hardly shows any difference from our young male (No. 36), except that the lores, cheeks, and a median stripe on the chin are decidedly ashy.

\section{Platycercus splendens, Peale.}

Platycercus splendens, Finsch, Mon. Papag. ii. p. 237 ; Layard, P. Z.S. 1875 , p. 425 ; Ibis, 1876 , p. 143 (first race only).

No. 52. Kandavu. Male. "Eyes red."

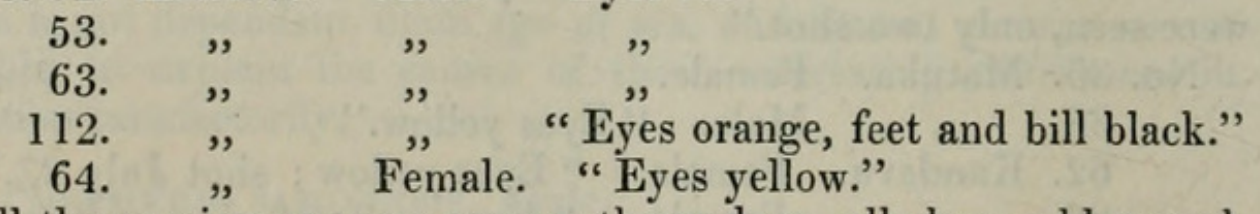

All the specimens agree among themselves; all show a blue neckcollar, but which differs in extent, in one (No.112) being interrupted 
by green; none of them have red spots on the rump, such as are sometimes shown in $P$. tabuensis. The size varies a good deal;
wings $8^{\prime \prime}$ to $8^{\prime \prime} 8^{\prime \prime \prime}$.

Mr. Layard (Ibis, 1876, p. 141) points out the characters of four different races of this Parrot occurring in the Fijis :-

(1) the bright crimson-bellied race, with broad blue collar, from

Viti-Levu and Kandavu, being the true Platycercus splendens, Peale;
(2) the Mathuata race, " maroon-bellied," with broad blue nuchal
collar ; collar;

(3) the Koro race, maroon-bellied with the faintest trace of the blue collar ; and

(4) the Taviuni race (P. taviunensis, Layard), "maroon-coloured and without a trace of the blue collar.'

Of these I have before me only one specimen from Taviuni, which, indeed, differs strongly from $P$. splendens. It has the same dark maroon-purplish coloration as $P$. tabuensis, and wants the blue neck-collar; besides it is considerably smaller (wings $7^{\prime \prime} 8^{\prime \prime \prime}$ ). As I have become convinced by a large series of $A$. tabuensis that in this species the blue collar is also sometimes almost wanting, I think this cannot form a specific character, even less than the purplish-red spots on the rump, which vary individually. If the smaller size should turn out to be constant, this dark form ought to be separated from the nearest-allied $\boldsymbol{A}$. tabuensis under the name of A. anne, Bourj. (P. taviunensis, Layard).

3. Platycercus personatus, G. R. Gray.

Platycercus personatus, Finsch, Mon. Pap. ii. p. 239; Layard, P. Z. S. 1875 , p. 425 .

No. 78. Levuka. Female. "Eyes orange, with streaks of red; bill and legs black. This bird was purchased alive."

4. Domicella solitaria (Gm.).

Domicella solitaria, Finsch, Mon. Papag. ii. p. 760.

Lorius solitarius, F. \& H. Orn. Central-Polyn. p. 23 ; Layard, P. Z.S. 1875 , p. 426 .

No. 37. Matuka. Female.

38.,$\quad$ Female.

39.,$\quad$ Female.

40. " Male.

"These birds were not common, although when they were seen a good number were in company. Eyes red and yellow."

No. 89. Kandavu. Male. "Eyes red; bill and legs yellow; stomach contained fruit.'

No. 99. Kandavu. Female. "Shot August 6."

100. " Male

5. Cuculus simus, Peale. Cuculus simus, F. \& H. Ornith. Central-Polyn. p. 28 ; Layard,
P.Z. S. 1875 , p. 426 .

No. 90. Kandavu. "Upper mandible and margin of lower black, 
base of the under flesh-colour or reddish; eyes dull orange; feet yellow; stomach contained parts of beetles and caterpillars. Shot August $6 . "-J . M$.

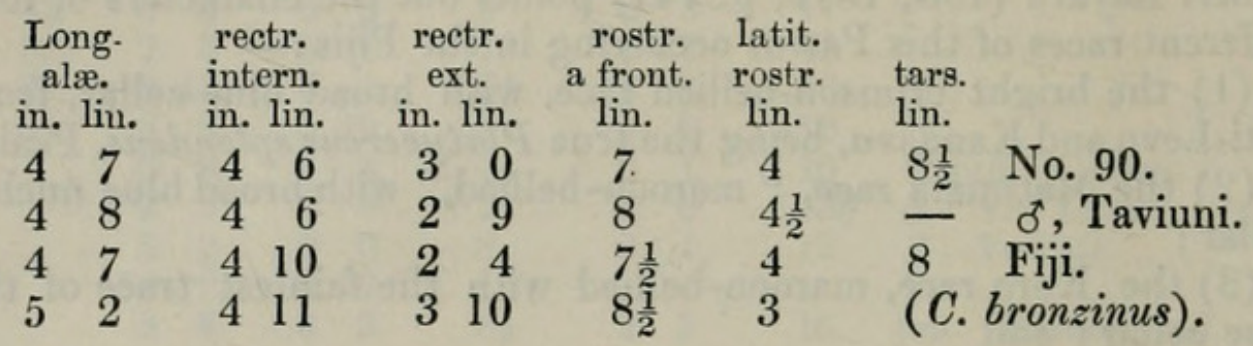

As this Cuckoo is only a migratory visitor to the Fiji group, it would be of interest to ascertain whither it resorts after leaving the islands, which at present are the only locality known for the species. Prof. Schlegel seems wrong in uniting it with the Australian $C$. $f l a-$ belliformis, Lath., which seems to be a rather larger bird, as is also C. bronzinus, Gray, of New Caledonia, which otherwise agrees nearly in coloration. Mr. Gould has since described a Cuckoo (Cacomantis castaneiventris, B. of Austr. Suppl. Part iv. 1867) from Queensland, which, judging from the plate (apparently a little exaggerated in colour), comes very near to $C$. simus, but is smaller (wings $\left.4^{\prime \prime} 2^{\prime \prime \prime}\right)$.

Our C. infuscatus (Orn. Central-Polyn. p. 31, t. v. f. 1), corresponding in size exactly with $C$. simus, will probably turn out to be a melanistic phase of the latter.

6. Hirundo tahitica, $\mathrm{Gm}$.

Hirundo tahitica, F. \& H. Ornith. Central-Polyn. p. 51 ; Layard, P.Z. S. 1875 , p. 430.

H. subfusca, Gould.

No. 45. Matuka. Female.

46. ", Female.

" Eyes black.",

No. 104. Kandavu. Female. "Eyes, bill, and legs black; stomach contained insects." $-J . M$.

This short-tailed Swallow comes nearest to H. javanica, Sparrm. ( $H$. domicola, Jerd.), but has a rather broader bill; the underparts below the ferruginous throat-portion are darker brownish; and the tail-feathers want the white spot on the inner web. I must mention, however, that in No. 45 the second right-hand tail-feather shows a very small pale spot on the inner web. The sexes are alike.

7. Collocalia spodiopygia, Peale.

Collocalia spodiopygia, Layard, P.Z.S. 1875, p. 428 (Fiji; habits).

No. 93. Kandavu. Female.

94. ," Male.

" Eyes, feet, and bill black; stomach contained parts of insects. Shot August 6." 
The Fiji specimens look a little lighter from below than those from Tonga and the Navigators'.

\section{Halcyon sacra (Gm.).}

Todirhamphus vitiensis, Cass.

Halcyon cassini, F. \& H. Orn. Central-Polyn. p. 40.

H. sacra and H. cassini, Layard, P. Z. S. 1875 , p. 427.

No. 61. Kandavu. Male. "Eyes and bill black."

95. " Male. "Eyes black, feet greyish; upper mandible black and margin of the under, rest of lower mandible pale red. Stomach contained a wasp and parts of other insects. Shot August 6." - J. $M$.

\section{No. 109. Kandavu. Male.}

110.

Male.

The Fiji specimens are generally darker and of a more brilliant blue, the neck-collar is washed with rufous, as are the sides of the vent and flanks, which in the Tonga birds are, like the neck-collar, almost pure white. But these differences are in certain specimens so indistinct that thereupon no specific characters can be based. H. cassini, Finsch \& Hartl., with an ill-defined superciliary stripe, rests on individual differences which are of no specific value. But I may remark that among a very large number of specimens examined by me from the Friendly and Fiji Islands, I never met with one having a white head showing only a blue vertical spot, as is represented in the right-hand figure of Sharpe's plate of $H$. sacra, which I think must still be kept separate as $H$. peali, F. \& H., from the Navigators'. In size the Fiji specimens are exactly the same as those from Tonga, and have not a longer bill, as has been stated by $\mathrm{Mr}$. Layard (P.Z.S. 1876, p. 501).

\section{Myzomela jugularis, Peale.}

Myzomela jugularis, F. \& H. Orn. Central-Polyn. p. 54, t. vii. f. 1, 2 ; Layard, P. Z.S. 1875, p. 431.

No. 43. Matuka. Male.

Female.

"Eyes black. These little birds were flying in considerable numbers about a large tree covered with red blossom; only a few, however, were brought on board."- $J$. $M$.

No. 59. Kandavu. Male. "Eyes and legs black."

$\begin{array}{lll}60 . & \quad & \text { Female. } \\ 85 . & \text { Male. } \\ 86 . & \Rightarrow & \text { Female. }\end{array}$

"Eyes and bill black; legs a bluish tinge with soles yellow. Stomach contained portions of insects. Shot August 5."

No. 70. Kandavu. Male.

In the female (No. 60) the red on the vertex or chin is more restricted; on the rump it is wanting in all; in No. 60 also on the vertex. No. 86 shows some red feathers on the rump but none on the vertex. 
10. Ptilotis carunculata (Gm.).

Ptilotis carunculata, Layard, P.Z. S. 1875, p. 432.

No. 47. Matuka. Male.

48. ", Female.

"These birds (the same as Nos. 12, 13, 14 and 15 from Tongatabu) did not appear so common as in Tongatabu, and seem to be rather smaller."- $J$. $M$.

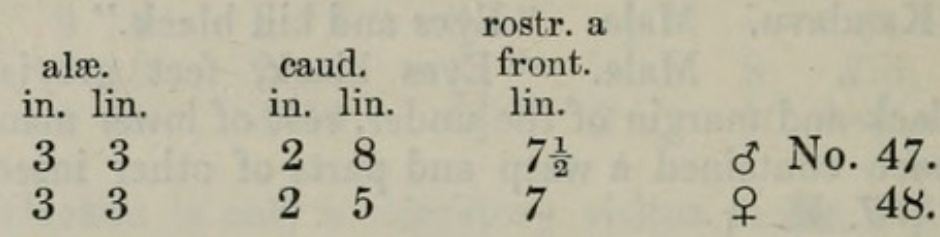

On comparing the measurements above given with those of the Tongatabu specimens, Mr. Murray's opinion as to the smaller size of the Fiji birds seems to be confirmed; but a reference to the table of measurements published by me (Journ. f. Orn. 1870, p. 126), taken from 29 specimens from the Navigators' and Tonga groups (those of the latter series having been sent over in spirits and mostly dissected by myself), will show all gradations of size, and the impossibility of separating the Fiji bird on account of its smaller size. In coloration specimens from the Fijis, Tonga, and Navigators' are precisely alike.

The occurrence of the true Pt. carunculata on the Fijis (doubted by me, Journ. f. Orn. 1872 , p. 36) has been already established by Mr. Layard. According to this gentleman the species is confined to the island of Loma Loma. He endeavours also to introduce a new species (Pt. similis), said to be peculiar to the island of Vanua Levu; but the short diagnosis (Ibis, 1876, p. 148), " having pale yellowish grey ear-tufts instead of bright golden yellow," seems to me insufficient to distinguish it. Perhaps it will turn out to be $P$. procerior.

Mr. Layard also remarks that in our 'Ornithology of Central Polynesia' we wrongly describe the iris to be white, as it is in fact brown or ashy-brown. As we never had an opportuity of seeing the bird alive, we could follow only the notice of Dr. Gräffe, who gave the iris as "white ;" but we also noticed "brown" (Peale), " ashygrey" (Latham), and "blue-black" (Forster).

\section{Ptilotis procerior, F. \& H.}

Ptilotis procerior, Orn. Central-Polyn. p. 62, t. v. f. 3 ; Layard, P. Z. S. 1875 , p. 431.

Nos. 73 and 74. Male. Levuka.

This species is well distinguished from the former ( $P$. carunculata) by having no true wattle, but a naked space below the earregion, surrounded by a blackish line, and by the absence of the yellow moustache, which is always visible in $P$. carunculata.

Through the Museum Godeffroy I have received many specimens for inspection from the following localities:-Ovalau, Vatu Lele, Vanua Levu, and Lavu-savu.

Young birds are of a sombre olive, without the yellowish tinge on 
the throat and breast. The size is also very variable, as is shown by the following table of measurements :-

\begin{tabular}{|c|c|c|c|c|c|}
\hline $\begin{array}{l}\text { Long. al. } \\
\text { in. lin. }\end{array}$ & $\begin{array}{l}\text { caud. } \\
\text { in. lin. }\end{array}$ & $\begin{array}{l}\text { rostr. a f } \\
\text { lin. }\end{array}$ & & & \\
\hline 39 & $\begin{array}{ll}3 & 0\end{array}$ & $10 \frac{1}{2}$ & & Type of & f $P \cdot$ procerior \\
\hline 310 & 211 & $9 \frac{1}{2}$ & & & \\
\hline 35 & 28 & $10^{\circ}$ & o & ", (Levuka). & 'Challenger, \\
\hline 36 & 211 & 9 & o & " , & \\
\hline 310 & - & 10 & 0 I & Vatu Lele. & sodeffr. \\
\hline 34 & 27 & $8 \frac{1}{4}$ & $0^{*}$ & $"$ & , \\
\hline 3 & 211 & $8 \frac{3}{4}$ & $0 \mathrm{I}$ & Vanua Levu. & ", \\
\hline 3 & 27 & $8 \frac{1}{4}$ & & Viti. & ", \\
\hline 31 & 26 & $7 \frac{3}{4}$ & q 1 & Vanua Levu. & $"$ \\
\hline $\begin{array}{ll}2 & 10 \\
2 & 11\end{array}$ & - & c. 8 & $\begin{array}{l}9 \\
9\end{array}$ & $\begin{array}{l}\text { Savu-sa } \\
\text { Viti. }\end{array}$ & ," \\
\hline & & & & & \\
\hline
\end{tabular}

Valuable notices on the habits of this species as observed by Mr. Th. Kleinschmidt, are published in the Journ. Mus. Godeffi. Heft xii. 1876, p. 13.

12. Ptilotis Provocator, Layard.

Ptilotis provocator, Layard, P. Z. S. 1875, p. 28.

P. xanthophrys, Finsch, Journ. Mus. Godeffr. Heft xii. 1876, p. 5.

No. 65. Kandavu. Male. “Eyes brown.” July 25.

66. " Female.

67.,$\quad$ Male.

$68 . \quad$ Male.

83.,$\quad$ Male.

84.,$\quad$ Female.

“ Eyes brown; legs a greenish tinge ; bill black. Stomach contained ants, spiders, grasshoppers."

No. 106. Kandavu. Female. Shot August 6.

111 .

Male. "Eyes brown; bill black; legs a greenish tinge.",

The specimen I described as $P$. xanthophrys was labelled " Navigators';" but this was a mistake, as this bird, which must bear Mr. Layard's previous name, is confined to the Fijis.

This is a well-marked, excellent species, always characterized by the yellow patch surrounding the eye, extending to the ear-region. Even the young bird (No. 84) shows this character, but differs otherwise in being underneath strongly tinged with olive-yellow, showing no whitish shafts, which form such conspicuous striæ even on the back of the old birds. The sexes are alike. The size, as usual in this genus, varies considerably individually.

13. Zosterops flaviceps, Peale.

Zosterops flaviceps, F. \& H. Orn. Central-Polyn. p. 52, t. vi. ; Layard, P. Z. S. 1875 , p. 430.

No. 71. Levuka. Female.

72. ", Male. “ Eyes black."

Proc. Zool. Soc.-1877, No. XLVIII. 
In coloration this species is so like $\boldsymbol{Z}$. westernensis (Quoy \& Gaim.) of Australia, that Dr. Hartlaub and Mr. Gould could find only in the somewhat stronger bill a ground of distinction ; but as the specimens now before me show only a difference of half a millimetre, this character can no longer stand. However, I now observe that the Fiji bird has the under tail-coverts of a deeper yellowish; so that I think $\boldsymbol{Z}$. flaviceps may be kept separate until more specimens show this difference also to be of no constant value.

\section{Zosterops explorator, Layard.}

Zosterops explorator, Layard, P. Z. S. 1875, p. 431.

No. 57. Kandavu. Female.

58. " " "Eyes black."

The discovery of this species is due to Mr. John Murray, of the 'Challenger' Expedition. As Mr. Layard has published only a short diagnosis, I think a full description will be necessary-the more so as the specimens now before me are the types.

Upper surface yellow olive-green, more yellow on the top and sides of the head and neck, changing into pure citron-yellow on the lores; chin, throat, and breast the same as the under tail-coverts; lower part of breast and remaining under surface yellowish white; flanks distinctly washed with pale brownish grey; under wing-coverts white; wing- and tail-feathers brown-black, narrowly margined externally with olive-green; remiges margined on their inner webs with white; there seems to be a narrow white eye-ring, surrounded by a narrower blackish one; bill blackish, lower mandible pale at base; legs plumbeous.

$\begin{array}{cccccc}\text { Long. tot. } & \text { al. } & \text { caud. } & \text { rostr. } & \text { tars. } \\ \text { in. } & \text { in. } \operatorname{lin} . & \text { lin. } & \text { lin. } & \text { lin. } \\ \text { c. } 4 & 2 & 2 \frac{1}{2} & 16 & 5 & 7 \frac{1}{2}\end{array}$

Both specimens are precisely alike.

This species comes nearest to $\boldsymbol{Z}$. xanthochroa, Gray, from New Caledonia ; but the olive-green of the upper parts inclines decidedly to yellow, and the yellow on the throat and breast is purer and brighter.

\section{Monarcha Lessoni (Quoy \& Gaim.).}

Monarcha lessoni, F. \& H. Orn. Central-Polyn. p. 88, t. vii. f. 5 ; Layard, P. Z. S. 1875, p. 434.

No. 87. Kandavu. Male. "Bill light blue, darker at the base; legs bluish ; eyes black. Stomach was crammed with broken parts of insects." - J. $M$.

No. 103. Kandavu. Male. Shot August 6. 116.

16. Myiagra Castaneiventris (J. Verr.)

Myiagra castaneiventris, F. \& H. Orn. Central-Polyn. p. 95, taf. ix. f. 2, 3; Layard, P. Z.S. 1875, p. 435.

No. 51. Matuka. Male. "Eyes black. Frequents chiefly the mangrove trees." 
No. 75. Levuka. Male. "Eyes black." Shot July 30.

101. Kandavu. Male. Shot Angust 6.

102. " Female.

114. ,

115. " Male.

I am surprised to find the specimen No. 101 marked " male ;" for it agrees with No. 114, marked "female," whereas the female, No. 102, shows the very different plumage of the black-throated males. If these statements are based on dissection, they would tend to prove a uniformity of both sexes-a fact very strange, and opposite to all we know at present of the members of this genus.

This species is confined to the Fijis, and does not occur on the Navigators', as stated wrongly in our 'Polynesian Ornithology.' The specimens described by us from Samoa were wrongly labelled. The representative species in the latter islands is M. albiventris, Peale ( $=M$. rufiventris, Elliot, Ibis, 1859, p. 393).

17. Pachycephala vitiensis, Gray.

Pachycephala vitiensis, Layard, P. Z. S. 1875, p. 433, et Ibis, 1876 , p. 154.

No. 69. Kandavu. Female. "Eses red." July 24.

bill brown. Shot August 5.",

" Eyes hazel ; legs a bluish tinge ;

Without having male specimens also on hand it is not possible to determine these specimens satisfactorily, as there has arisen a great confusion since Mr. Layard pointed out the existence of 5 or 6 species in the Fijis. As the specimens are collected in Kandavu they ought to be "P. vitiensis," which, according to Mr. Layard, is confined to this island; and, judging from Mr. Gray's short description, they would belong to this species. But I may mention that the female specimen described and figured by us s. n. P. vitiensis (Orn. Central-Polyn. p. 73, t. viii. f. 3), apparently belongs to the species described since as P. torquata, Layard (P. Z. S. 1875, p. 433).

18. Lalage maculosa (Peale).

No. 49. Matuka. Female. 50 .

113. Kandavu. M̈ale. “Eyes hazel; bill blackish ; legs a greenish tinge."

On this species see above, p. 724 .

19. Aplonis vitiensis, Layard.

Aplonis vitiensis, Layard, P. Z. S. 1876. p. 502.

A.tabuensis, F. \& Hartl. (nec Gm.), Ornithol. Central-Polyn. p. 103 , t. x. f. 2 .

No. 41. Matuka. Male.

42. ", Female.

" Eyes dark red or brown. This is the same bird as Nos. 8, 9, 
25 (i. e. A.tabuensis), from Tongatabu, and appeared to be not at all common: only two specimens were obtained. These seem smaller, and altogether a variety when compared with those from Tongatabu."-J.M.

The distinctive characters of this species (which, following Peale, we formerly erroneously described as the true $A$. tabuensis) I have explained in my paper on the birds of Eua (see below).

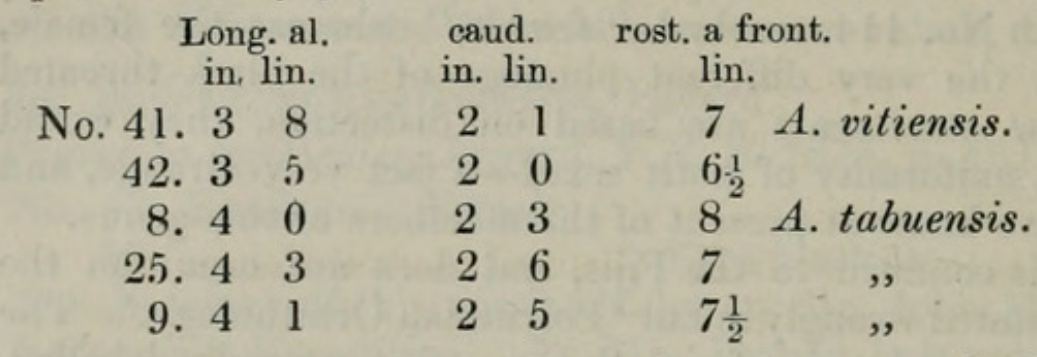

The comparison of the dimensions between the Fiji and Tonga specimens, given above, will show a considerable difference : but I must remark that they cancot stand as of specific value; for I have measured specimens from Tonga as small as those from Fiji, and also large specimens from Fiji.

\section{Chrysenna victor, Gould.}

Chrysoena victor, Finsch, P. Z. S. 1873, p. 733, et 1875, 557; id. Juurn. Museum Godeffroy, Heft xii. (1876) p. 10; Layard, P. Z. S. 1875 , p. 437 .

An old specimen in full plumage from Taviuni.

21. Chrysena viridis, Layard.

Chrysæena viridis, P. Z.S. 1875 , pp. 151 et 437.

No. 55. Kandavu. "Sex not certain. Eyes yellow; legs violet; bill green."

No. 56 . Kandavu.

No. 81. Kandavu. "Male. Bill green; legs violet; eyes white. Stomach contained green fruit with stones."

No. 9l. Kandavu. "Male. Eyes white; bill green; legs violet."

No. 92. Kandavu. "Male. Stomach contained a fruit about the size of a cherry, with a large hard stone. Shot August 6." $-J . M$.

This well-marked species, distinguished by the yellow head and under tail-coverts, is not the young of $C$. luteovirens, as erroneously supposed by me (Journ. Mus. Godeffr. Heft xii. p. 10). It seems to be confined to the island of Kandavu, and was first discovered, as Mr. Layard notices, by the 'Challenger' Expedition.

22. Columba vitiensis, Quoy \& Gaimard.

Columba vitiensis, F. \& H. Ornith. Central-Polyn. p. 137, t. xi. f. 2 ; Layard, P.Z. S. 1875 , p. 437 , et 1876 , p. 496.

No. 54. Male. Kandavu. "Eyes yellow; legs and upper part reddish, and beak, except tip, red."

No. 97. Male. Kandavu. "Legs and eyes red, eyelid red; bill, base red, tip green. The stomach contained the seeds of the 
little red pepper so common on shore (chili). The gizzard was quite ordinary, and contained nothing of the nature of that in Nos. 88, 96 (Carpophaga latrans). The first specimen we have taken of this pigeon. Shot August 6."

No. 107. Male. Kandavu.

This pigeon seems also peculiar to the Viti group, slthough assigned in our book and by Mr. Layard also to the Navigators' Islands. On the specific distinctness of the representative form in the latter group (C. castaneiceps, Peale), conf. Finsch, Journ. f. Ornith. 1872, p. 47.

\section{Carpophaga latrans, Peale.}

Carpophaga latrans, F. \& H. Ornith. Central-Polyn. p. 140 ; Layard, P.Z. S. 1875, p. 438.

No. 88. Kandavu. Female. "Cere and eyes red; legs red or purplish; bill black. The stomach contained the fruit of some tree unknown to $\mathrm{me}^{\mathrm{l}}$. The coat of the stomach had hard pupilla-like ossifications of a circular form, in two or three rows. These indurations are composed of a horny substance. Shot August 5."

No. 96. Kandavu. Female. " Eyes red; bill black; cere red; legs purple. Stomach contained a large green fruit. Same as No. 88. Shot August 6." - J. M.

These examples agree with specimens from Viti-Levu. The species is peculiar to the Fiji group, and, according to Mr. Layard, is found on nearly all of the islands.

\section{Ardea sacra, Gm.}

Ardea sacra, Layard, P. Z. S. 1875, p. 440 (Fiji).

No. 33. Matuka. Female. July 24.

A uniform slate-coloured specimen, with white chin-stripe.

25. Anas superciliosa, Gm.

Anas superciliosa, F. \& H. Orn. Central-Polyn. p. 213 ; Layard, P. Z.S. 1875 , p. 440.

A. pelewensis, H. \& F. Journ. Mus. Godeffr. Heft viii. 1875, p. 40.

No. 98. Kandavu. Male. "Eyes dull pink; bill black; legs flesh-colour with a salmon tinge. Stomach contained worms and mud. Shot August 6."-J. M.

No. 108. Kandavu. Male.

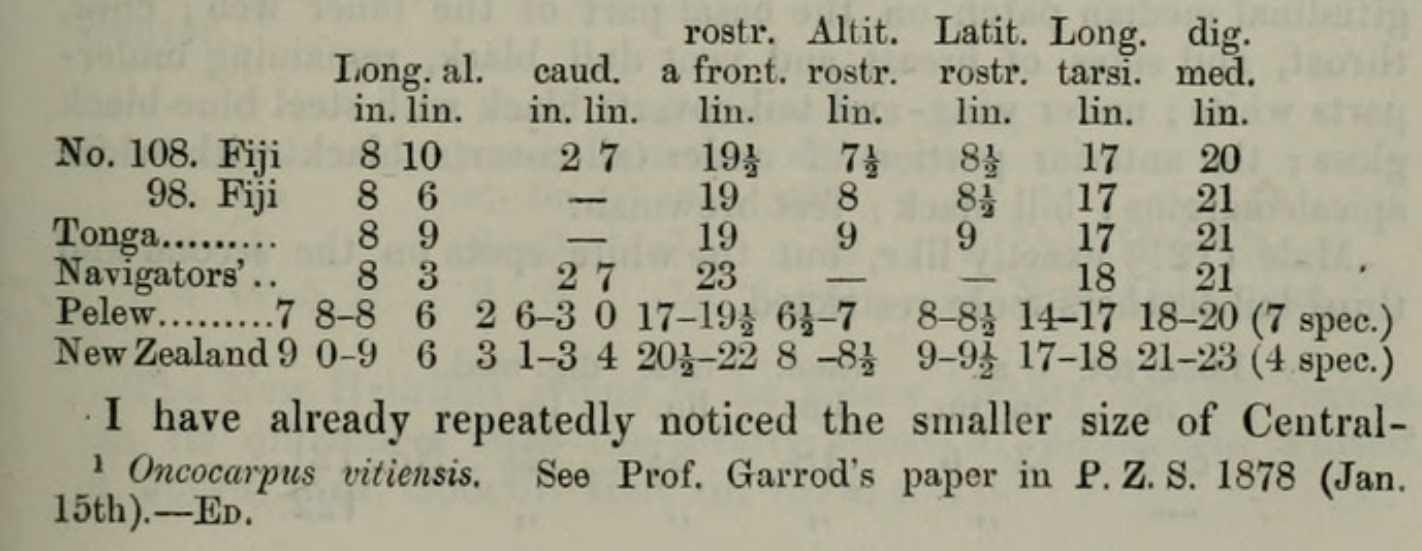


Polynesian specimens in comparison with examples of the true A. superciliosa from New Zealand. The Fiji specimens before me confirm my statement; but going again close into the matter, I feel rather doubtful with respect to our $A$. pelewensis. I formerly thought it possible to separate this form specifically by the buff coloration of the sides of head, chin, and throat, and by the imperfect dark moustache-stripe always so conspicuous in NewZealand specimens; but the Fiji specimens prove these characters not to be constant, as No. 108 agrees perfectly with the Pelew bird, whereas No. 98 shows the dark moustache. The rusty-brown longitudinal band on the outer web of the last secondaries also, as I have noticed since, is not a constant character for $A$. pelewensis. Therefore only the smaller size remains noticeable; but in comparing the table of measurements given above it seems rather difficult to found upon this an available specific character; and I think A. pelewensis cannot be allowed to be more than a scarcely smaller race.

\section{Birds of Api, New Hebrides.}

"Our parties were landed for about three hours on Api, with orders not to wander far from the beach. During this time six specimens of birds were obtained, belonging to five species." $-J . M$.

\section{Hirundo tahitica, Gm.}

No 120. Api. Female. "Eyes, legs, and bill black. Stomach contained insects."-J.M.

This example agrees exactly with specimens from Fiji.

2. Collocalia uropygialis, G. R. Gray.

Collocalia uropygialis, G. R. Gray, Ann. \& Mag. Nat. Hist. ser. 3, vol. xvii. p. 123 (New Hebrides.)

No. 121. Api. Male.

122. " " . "Legs, eyes, and bill black. Stomach contained insects."-Murray.

This is a very remarkable species, of which I subjoin a description.

Upper parts black, with a very distinct dark steel-green stripe on the head, back, and shoulders, which, under certain lights, changes into steel blue-black on the wings and tail; on the rump a broad band of pure silky white; second and third tail-feathers with a longitudinal median patch on the basal part of the inner web; chin, throat, and sides of breast and vent dull black, remaining underparts white; under wing- and tail-coverts black with steel blue-black gloss; the anterior portion of under tail-coverts black with white apical margins; bill black; feet brownish.

Male (121) exactly like, but the white spots on the second and third tail-feathers more restricted.

\begin{tabular}{|c|c|c|c|c|}
\hline $\begin{array}{l}\text { Long. tot. } \\
\text { in. }\end{array}$ & $\begin{array}{l}\text { al. } \\
\text { in. lin. }\end{array}$ & $\begin{array}{c}\text { caud. } \\
\text { lin. }\end{array}$ & $\begin{array}{l}\text { tars. } \\
\text { lin. }\end{array}$ & $\begin{array}{l}\text { dig. med. } \\
\text { lin. }\end{array}$ \\
\hline c. 3 & & 18 & $3 \frac{1}{2}$ & $2 \frac{1}{2}$ \\
\hline
\end{tabular}


The tips of the wings extend beyond the end of the tail about 14 lines; the tail is entire.

The New-Caledonian bird (C. leucopygia, Wall. P. Z. S. 1863, p. 384) seems to differ, as we learn from M. Verreaux's original description (C. linchi, Verr. \& Des Murs, Rev. et Mag. Zool, 1S62, p. 129), specifically in the rhachis of the rump-feathers being black, and in the want of the white spot on the inner web of the second and third tail-feathers.

\section{Halcyon Julie (Heine).}

Halcyon julia, Sharpe, Mon. Kingf. p. 227, tab. 86 ; Tristram, Ibis, 1876, p. 260.

Dacelo grayi, Schleg. Mus. P. B. Alced. (1863), p. 37.

H. sacra, F. \& H. Orn. Central-Polyn. p. 32 (spec. ex New Hebrides and New Ireland? p. 34).

No. 117. Api. Female. "Eyes black; upper mandible black, lower flesh-colour; legs greyish; the stomach contained insects, and a small molluscous shell "- $J$. $M$.

When placed among an extensive series of H. sacra, this specimen seemed to be nothing more than a dull-coloured specimen of that species, having the greenish shine of the back exactly the same as in No. 7 (from Tongatabu); but the same dull green also prevails on the head; and this would form the only mark of distinction. The rufous band round the head is not so developed as in Sharpe's plate; there is only a buff supercilium; and the head-band is only indicated by some buff feathers; the neck-collar is white, not buff; the black band which runs from beneath the eyes round the hind neck is very narrow.

A specimen in the Bremen Museum, said to be from New Ireland (procured from Mr. Frank), and described by us (l.c.) as H. sacra, agrees perfectly with Sharpe's plate, and may be considered to be also $H$. julice.

\section{Artamus melaleucus, Forst.}

Loxia melaleuca, Forst., Licht. Descr. Anim. 1844, p. 272.

No. 119. Api. Male. "Bill light blue, the tip black; eyes hazel ; legs black; the stomach contained insects, chiefly beetles." $-J . M$.

Exactly like specimens from New Caledonia; the wing a trifle shorter.

\begin{tabular}{|c|c|c|c|c|}
\hline $\begin{array}{l}\text { Long. al. } \\
\text { in. lin. }\end{array}$ & $\begin{array}{l}\text { caud. } \\
\text { in. lin. }\end{array}$ & $\begin{array}{l}\text { rostr. a } \\
\text { front. } \\
\text { in. }\end{array}$ & $\begin{array}{l}\text { Latit. } \\
\text { rostr. } \\
\text { a basi. } \\
\text { in. }\end{array}$ & $\begin{array}{l}\text { Long. } \\
\text { tars. } \\
\text { in. }\end{array}$ \\
\hline $\begin{array}{ll}4 & 9\end{array}$ & 23 & $7 \frac{x}{2}$ & $4 \frac{1}{2}$ & 7 New Hebrides. \\
\hline $\begin{array}{lll}4 & 11-5 & 2\end{array}$ & 5 & $7 \frac{\bar{I}}{2}$ & $4 \frac{1}{2}$ & 8 New Caledonia. \\
\hline
\end{tabular}

The New Hebrides seems to be a new locality for this species. On its differences from the nearly allied $A$. pelewensis, Finsch, cf. Journ. Mus. Godeffr. Heft xii. 1876, p. 41. 


\section{Carpophaga pacifica (Gm.)}

No. 118. Api. "Male, young. This bird was in poor condition, and had nothing in the stomach. Bill blackish-blue; legs dull red eyes brown."- J. $M$.

This is a young bird, with not full-grown wings and tail-feathers (wings only $6^{\prime \prime} 11^{\prime \prime \prime}$, tail $4^{\prime \prime}$ ), but in coloration exactly like older ones from the Tongas. Some of the tail-feathers and secondaries show the singular hairy filaments which denote a young bird still unable to fly.

\section{Birds of Tahiti, Society Group.}

The 'Challenger' remained at Tahiti from the 18th of September till the 2nd of October, 1875. Sixteen specimens of birds were collected, which I refer to four species.

1. Callocalia fuciphaga (Thunb.).

Callocalia cinerea, Finsch, Journ. Mus. Godeffr. Heft xii. 1876 , p. 25.

C. fuciphaga, Wall. P.Z.S. 1863, p. 384 ; Sclat. P.Z.S. 1865, p. 616 .

No. 559. Tahiti. Male.

No. 560 .

No. 561

” Female. Eyes black.

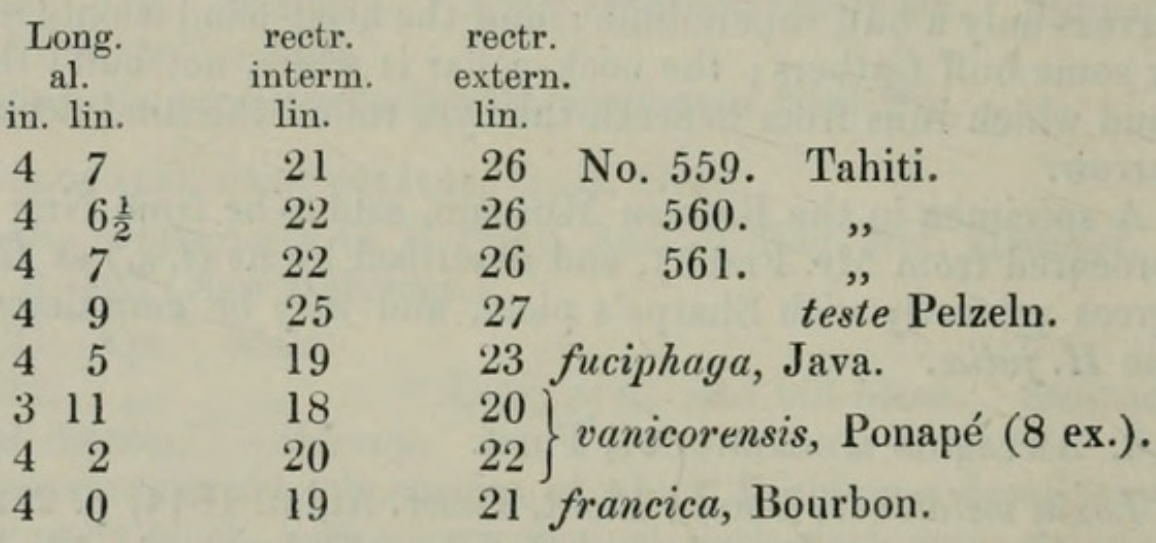

Having now, for the first time, the opportunity. of examining specimens of the Collocalia of Tahiti, I find no specific distinctions from the well-known $C$. fuciphaga, so widely distributed in the Indian and Malay archipelagos. The specimens before me are not of so light a greyish-brown as one would expect from the descriptions sent me by Herr von Pelzeln; on the contrary, the whole undersurface is a little darker than in Javan specimens; but the difference is so slight that no character can be based on it.

C. vanicorensis corresponds in coloration exactly, but may perhaps be kept separate on account of the smaller size. From the latter, $C$. francica, Gm. (from Bourbon and Madagascar), seems scarcely separable; only the under tail-coverts show a more intense green gloss. Mr. Wallace $(l . c$. ) is perhaps right in uniting also these two latter species under $C$. fuciphaga. 
2. Halcyon veneratus, Gm.

Halcyon veneratus, Sharpe, Mon. Kingf. p. 245, t.

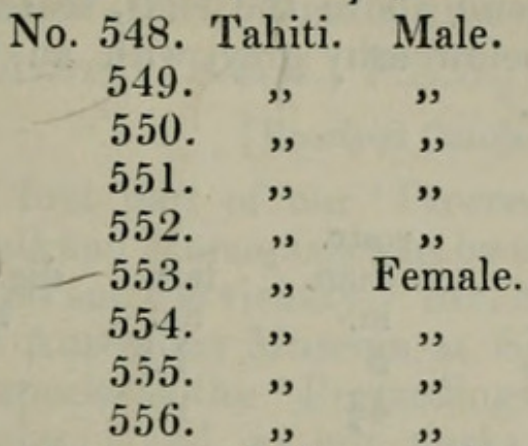

The excellent series before me does not confirm the view that either the dark band across the breast, or the more bluish green, or the duller brown coloration of the upper parts is peculiar to a certain state of age or sex. All are apparently old specimens, and show every gradation in these characters.

The dull brownish tone passing into verdigris prevails in most of tue specimens; only No. 5, 548 (male), and 554 (female), are more of a reenish-blue, especially on the head and wings; these specimens have no dark breast-band, this being only faintly shown by rusty tips of the feathers. No. 551 (male) has scarcely any indication of a breast-band (resembling, therefore, the right-hand figure on Sharpe's plate). In No. 5, 550 (male) and 552 (male) the breast-band is on a rusty ground-colour, speckled with blackish, in the remaining specimens more or less of a brownish black.

The length of " wings," varies from $3^{\prime \prime} 3^{\prime \prime \prime}$ to $3^{\prime \prime} 7^{\prime \prime \prime}$.

Mr. Layard enumerates H. veneratus, from Tonga (P.Z.S. 1876, p. 501), but probably obtained the specimen here.

\section{Ptilonopus purpuratus (Gm.)}

Ptilonopus purpuratus, F. \&. H. Orn. Central-Polyn. p. 122.

No. 557. Tahiti. Male, 558. " Female.

"Feet violet; eyes orange; bill green at the base, tip yellow." $-J . M$.

I am pleased to have an opportunity of examining the Ptilonopus of the Tahiti group, which is so rare in collections; and as the description given in the 'Ornithology of Central Polynesia' (being copied from Peale) turns out to be incorrect in some points, I think it necessary to give a new one.

Male. Front and vertex delicate purplish-lilac, forming a pale and, not as usual in the members of this genus, circumscript headcap ; remainder of head, neck, and under surface ashy-grey with only a very faint greenish tinge, more visible on the middle of the breast and vent; throat-feathers bifurcate in the centre tinged with pale dull yellow-greenish; lower vent whitish, under tail-feathers citronyellow; tarsal feathers ashy-grey; back, wings, and tail bright grass-green; on the mantle and shoulders with a bronzy shine under certain lights; remiges slaty black on the outer webs, tips dark 
green; secondaries margined externally very narrowly with yellow ; under wing-coverts ashy grey, the under-surface of wings darker; tail-feathers with a grey cross band above the ends, scarcely visible on the outer web; tail from below ashy grey, with an ill-defined white cross band above the end.

Female like the male.

\begin{tabular}{|c|c|c|c|c|c|}
\hline $\begin{array}{l}\text { Long. } \\
\text { tot. } \\
\text { lin. } \\
\text { c. } 8\end{array}$ & \begin{tabular}{cc}
\multicolumn{2}{c}{ al. } \\
in. & lin. \\
5 & 5 \\
5 & 7
\end{tabular} & \begin{tabular}{cc}
\multicolumn{2}{c}{ caud. } \\
in. & lin. \\
2 & 9 \\
2 & 9
\end{tabular} & $\begin{array}{l}\text { rostr. } \\
\text { a front. } \\
\text { in. } \\
5 \\
4 \frac{1}{2}\end{array}$ & $\begin{array}{r}\text { tars. } \\
\text { lin. } \\
12 \\
12\end{array}$ & $\begin{array}{c}\text { dig. med. } \\
\text { lin. } \\
9 \frac{1}{2}\end{array}$ \\
\hline
\end{tabular}

Peale's figure is somewhat incorrect; the head appears too blue, and has no purplish-red margin; the remiges are not coloured blue.

The very interesting fact of the very localized distribution of the numerous species of the genus Ptilonopus in the Pacific archipelago is most strongly exemplified by this species, peculiar to the Tahiti group. The pale purplish-lilac cap and the want of the usual dark vent-spot, distinguish this species at once as regards coloration. But, besides, it is very well characterized by the

A

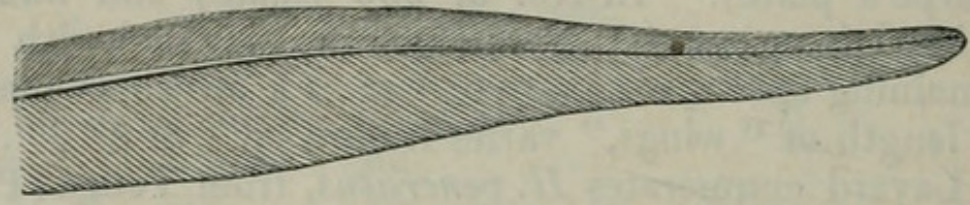

B

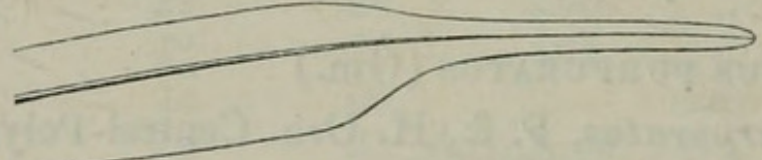

form of the first primary, which is shown in figure A, whereas in the other Polynesian species before me (Pt. fasciatus, porphyraceus. pelewensis, ponapensis, perousei, and'dupetit-thouarsi) this feather is much attenuated in the apical half (see fig. B.).

4. Ardea sacra, Gm.

No. 562. Tahiti. Female.

563. " " Young.

"Eyes orange; feet and legs greenish in the adult."---J.M.

No. 562 is white, strongly developing slate-blue feathers; No. 563 is slate-coloured, with a broad white chin-stripe. 


\section{$2 \mathrm{BHL}$ Biodiversity Heritage Library}

Grote, Arthur. 1877. "November 6th, 1877." Proceedings of the Zoological Society of London 1877, 679-754.

https://doi.org/10.1111/j.1469-7998.1877.tb00538.x.

View This Item Online: https://www.biodiversitylibrary.org/item/90449

DOI: https://doi.org/10.1111/j.1469-7998.1877.tb00538.x

Permalink: https://www.biodiversitylibrary.org/partpdf/73558

\section{Holding Institution}

Natural History Museum Library, London

\section{Sponsored by}

Natural History Museum Library, London

\section{Copyright \& Reuse}

Copyright Status: Public domain. The BHL considers that this work is no longer under copyright protection.

This document was created from content at the Biodiversity Heritage Library, the world's largest open access digital library for biodiversity literature and archives. Visit BHL at https://www.biodiversitylibrary.org. 